\title{
Sözleşmesel Çerçevede Meydana Gelen Müteselsil Borçlulukta Borçlu Temerrüdü
}

\section{Davut Armağan*}

Öz

Bir borç ilişkisinin borçlu tarafinda birden fazla borçlu yer alabilir. Alacaklı karşısında birden fazla borçlunun yer alabildiği hallerden biri de müteselsil borçluluk halidir. Müteselsil borçluluk borç alttna giren tarafların iradesinden kaynaklanabileceği gibi, kanunlarda müteselsil borçluluğa ilişkin kabul edilmiş düzenlemelerden de kaynaklanabilir. Borçluların sözleşmesel bir ilişki çerçevesinde alacaklı karşııında müteselsil borçlu olmaları, iradelerini bu yönde ortaya koymaları halinde meydana gelebilir. Öte yandan tarafların bu yönde açık bir iradeleri olmasa dahi kanun gereği sözleşmesel çerçevede müteselsil borçlu olma gündeme gelebilir. Bütün bu hallerde sözleşmesel olarak alacaklıya karşı borç altına giren müteselsil borçluların edimlerini zamanında ifa etmemeleri mümkündür. Bu durumda müteselsil borçluların temerrüdü söz konusu olur. Müteselsil borçluların temerrüdü bakımından temel kural, bunun şartları ve sonuçlarının her bir borçlu bakımından bağımsız olarak değerlendirilmesidir. Ancak bu temel kuralın istisnaları da bulunmaktadır.

Bu çalışmanın amacı, sözleşmesel çerçevede meydana gelen müteselsil borçlulukta müteselsil borçlunun/borçluların temerrüdünün gerçekleşme şartlarının neler olduğunun tespiti ve müteselsil borçlulardan birinin, birkaçının veya tamamının temerrüdü halinde bu temerrüdün sonuçlarının neler olduğunun incelenmesidir.

\section{Anahtar Kelimeler}

Müteselsil borçluluk, Müteselsil borçlu, Temerrüt, Sözleşme, Tazminat

\section{Debtor's Default in Joint Indebtedness which Occurs within A Contractual Framework}

\section{Abstract}

More than one debtor can take part at the debtor side in a debt relationship. One of the situations where more debtor takes part against the creditor is the joint indebtedness. Joint indebtedness can arise from the will of binding parties as well as the regulations regarding joint indebtedness. Becoming joint debtors against a creditor within a framework of contractual relationship can occur when debtors reveal their wills in this direction. Furthermore, becoming joint debtors in a contractual framework can occur also by law, even if joint debtors do not have such will. It is possible that the joint debtors do not perform on time who incurs a contractual debt. In such cases, default of joint debtors is in question. Independent consideration of conditions and results of the default of joint debtors is the main rule. But there are also exceptions about this main rule.

The aim of this work is the determination of the conditions of the default of joint debtor/debtors in joint indebtedness, which occurs within a contractual framework and examination of the results of the default when one, some or all of joint debtors incur in default.

\section{Keywords}

Joint indebtedness, Joint debtor, Default, Contract, Compensation

\footnotetext{
Sorumlu Yazar: Davut Armağan (Arş. Gör., Doktora Öğrencisi) İstanbul Medipol Üniversitesi, Hukuk Fakültesi, Medeni Hukuk Anabilim Dalı, İstanbul Medipol Üniversitesi Sosyal Bilimler Enstitüsü Özel Hukuk, İstanbul, Türkiye. E-posta: darmagan@medipol.edu.tr ORCID: 0000-0001-6322-7120
}

Atrf: Armagan D, "Sözleşmesel Çerçevede Meydana Gelen Müteselsil Borçlulukta Borçlu Temerrüdü" (2019) 77(2) İstanbul Hukuk Mecmuası 617. https://doi.org/10.26650/mecmua.2019.77.2.0006 


\section{Extended Summary}

All debtors are liable for all of the obligations in joint indebtedness. Also, the creditor has the right to claim this from one, some or all of the debtors. Joint indebtedness can arise from the regulations or wills of the parties. The coming together of joint debtors in a contractual framework also can arise from both the regulations and wills of the parties. In all these cases, if joint debtors do not perform on time, then default of joint debtors is mentioned. Obligations of joint debtors are relatively independent from each other. As a result of this, principally action of a joint debtor has effect only on that joint debtor. Accordingly, default of a joint debtor has only effect only on this debtor who is in default. But exceptionally, it is possible that the parties can agree that responsibility of all joint debtors from the results of default of a particular joint debtor.

Obligations of joint debtors can fall due on different dates, and accordingly, default dates can differ when performance times of joint debtors are different from each other. If one of the joint debtors has a right to avoid performance, this prevents this debtor from debtor's default. Notice principally causes the default of the debtor who has received notice. But a contra agreement regarding this is also possible. If there is a situation which makes notice unnecessary for a joint debtor, this debtor falls into default without a notice. The performance of the obligation must be possible for the occurrence of the default. If the object of the performance is impossible in terms of all debtors, all debtors get out of their debts. If the object of performance becomes impossible with a fault of a joint debtor, all joint debtors must be responsible de lege ferenda. If one of the joint debtors puts a creditor to creditor's default, other joint debtors also benefit from this situation.

Compensation of delay, which is a general result of debtor's default, can only be demanded from the joint debtor who is in default. If more than one joint debtor falls in default because of their fault, these are jointly responsible for the compensation of delay. Even if one joint debtor who does not fall in default, distinguishes obligation with performance, compensation of delay can still be demanded from the joint debtor who falls in default. If a force majeure or fortuitous events occur during the period of default of one joint debtor, this joint debtor is responsible for this situation. If the same situation occurs during the period of default of more than one joint debtor, these are jointly responsible.

If one of the joint debtors of a pecuniary obligation falls into default, this debtor is obliged to pay interest for the default. If more than one joint debtor falls into default, these are jointly responsible. But at this point, default dates, interest rates and the capital debt have importance. Because according to these elements, the amount of interest for default can differ. Therefore, a distinction must be made during the 
consideration of the jointly responsible parts of the debt. If the creditor still has a damage which does not compensate with the interest for default, it can be claimed from the joint debtor who falls into default with fault.

In bilateral contracts the creditor, who wants extra rights to benefit, should give an extra period of time to the joint debtor who falls into default. This time periods must be reasonable for each joint debtor. It can be situations in which the creditor should give an extra period of time to some joint debtors while it is not necessary to give to the others, according to TCO Art. 123. When the creditor makes choice, this has only effect for the joint debtor which this right turns to.

Compensation for damage for non-performance can only be demanded from the joint debtor who falls into default with fault. If other join debtors who do not fall into default, distinguish the obligation, this compensation cannot be demanded from the debtor who is in default. If more than one joint debtor falls into default with fault, these joint debtors are responsible for the compensation for damage for nonperformance of obligation.

Withdrawal from the contract is possible when all joint debtors incur in default. The creditor must declare his withdrawal will to all joint debtors. 


\section{Sözleşmesel Çerçevede Meydana Gelen Müteselsil Borçlulukta Borçlu Temerrüdü}

\section{Giriş}

Borç ilişkisi, alacaklı ve borçlu arasındaki hukuki ilişkiyi ifade etmekte olup alacaklı ile borçlu arasında bir veya daha fazla alacak hakkının yanı sıra bazı ikincil hak ve borçları içerir ${ }^{1}$. Bu ilişki taraflar arasındaki çeşitli borçların kaynağını oluşturur² Borç ilişkisinde taraf olarak prensip itibariyle alacaklı ve borçlu olmak üzere iki kişi bulunur ${ }^{3}$. Ancak borç ilişkisinin alacaklı veya borçlu taraflarında birden fazla kişinin bulunması da mümkün olabilir". Diğer bir deyişle bir borçlunun karşısında birden fazla alacaklının bulunması mümkün olabileceği gibi, bir alacaklının karşısında da birden fazla borçlu bulunabilir. Bu son halde belirtilen tarzda borçluluk da kısmi borçluluk, kümülatif borç ilişkisi, elbirliği halinde borç ilişkisi, bölünemeyen borç ve müteselsil borçluluk gibi çeşitli şekillerde meydana gelebilir5.

Çalışmamızın konusunu alacaklının karşısında birden fazla borçlunun yer aldığı hallerden biri olan müteselsil borçlulukta, bir sözleşme ile alacaklının karşısında yer alan borçluların temerrüdü ve bunun hukuki sonuçları oluşturmaktadır. Tek bir alacaklının karşısında yer alan tek bir borçlunun, borcunu zamanında ifa etmemesi sonucu temerrüde düşmesi ile birlikte alacaklı borçluya karşı birtakım haklara sahip olur. Bunun gibi alacaklının sözleşme ilişkisi içerisinde bulunduğu ve karşısında müteselsil olarak borçlu bulunan birden fazla kişiden birinin, birkaçının veya hepsinin borcunu zamanında ifa etmeme ihtimalleri mevcuttur. Böyle bir durum ile karşılaşan alacaklının, borçluların tamamını temerrüde düşürüp düşüremeyeceği, hangi haklara

Fikret Eren, Borçlar Hukuku Genel Hükümler (23. baskı, Yetkin 2018) 22. Borç ilişkisi hakkında bilgi için bkz. Necip Kocayusufpaşaoğlu and others, Borçlar Hukuku Genel Bölüm, C. I (5th edn, Filiz Kitabevi 2010), §2, para. "2ff”; Ali N İnan and Özge Yücel, Borçlar Hukuku Genel Hükümler (4th edn, Seçkin 2014) "81ff”; Eren (n 1) "22ff”; İhsan Erdoğan, Borçlar Hukuku Genel Hükümler (3rd edn, Gazi Kitabevi 2017) "15ff”; Özer Seliçi, Borçlar Kanununa Göre Sözleşmeden Doğan Sürekli Borç İlişkilerinin Sona Ermesi (IÜHF Yayınları 1976) "1ff”; Hüseyin Hatemi and Emre Gökyayla, Borçlar Hukuku Genel Bölüm (4th edn, Vedat Kitapç1lı 2017) §2, "para 1ff”.

2 M. K Oğuzman and M. T Öz, Borçlar Hukuku Genel Hükümler C. 1 (16th edn, Vedat Kitapç1lı 2018) para. 12; Kocayusufpaşaoğlu and others (n 1), §2, para. 4; Pierre Tercier, Pascal Pichonnaz and H. M Develioğlu, Borçlar Hukuku Genel Hükümler (On İki Levha 2016), §3, para. "105ff”; Selahattin S Tekinay and others, Borçlar Hukuku Genel Hükümler (7th edn, Filiz Kitabevi 1993) "5ff".

3 Eren (n 1) 1223; Hatemi and Gökyayla (n 1) §36, para. 1; Claire Huguenin, Obligationenrecht Allgemeiner und Besonderer Teil (2nd edn, Schulthess 2014) N. 2279; Wolfgang Fikentscher and Andreas Heinemann, Schuldrecht Allgemeiner und Besonderer Teil (11.th edn, De Gruyter 2017) para. 760; Ernst A Kramer and Thomas Probst, Obligationenrecht Allgemeiner Teil (2.th edn, Helbing Lichtenhahn 2013) para. 542; Andreas Weiss, Solidarität nach Art. 143-149 des Schweizerischen Obligationenrechts unter besonderer Berücksichtigung der Verjährung (Schulthess 2011) 10.

4 Kenan Tunçomağ, Türk Borçlar Hukuku Genel Hükümler, C. 1 (Sermet Matbaası 1976) 1024; Eren (n 1) 1223; Erdoğan (n 1) 251; Safa Reisoğlu, Türk Borçlar Hukuku Genel Hükümler (25th edn, Beta 2014) 442; Eugen Bucher, Schweizerisches Obligationenrecht: Allgemeiner Teil ohne Deliktsrecht (2.th edn, Schulthess 1988) 486; Ingeborg Schwenzer, Schweizerisches Obligationenrecht Allgemeiner Teil (7th edn, Stämpfli 2016) para. 88.01.

Bu haller ile ilgili olarak ve müteselsil borçluluktan farkları için bkz. M. K Oğuzman and M. T Öz, Borçlar Hukuku Genel Hükümler C. 2 (14th edn, Vedat Kitapç1lı 2018) para. “1338ff”; Eren (n 1) “1224ff”; H. Oser and W. Schönenberger, İsviçre Borçlar Kanunu Şerhi, Madde 110-183 (Şerhin İkinci Basılışının Tercümesi, Adalet Bakanlığı 1950) "900ff”; Bernhard Berger, Allgemeines Schuldrecht (3rd edn, Stämpfli 2018) para. "2404ff"; Weiss (n 3) "23ff". Bu hallere ilişkin olarak ayrıntılı bilgi için ayrıca bkz. Kadir B Kapancı, Birlikte Borçlulukta Borçlular Arası İlişkiler (2.th edn, Vedat Kitapçıllk 2014) "7ff". 
sahip olduğu ve bu hakları borçluların tamamına karşı kullanıp kullanamayacağı gibi çözülmesi gereken bir takım problemler ortaya çıkar.

Çalışmada öncelikle müteselsil borçluluğun tanımı ve özellikleri belirtilecek ve ardından alacaklı karşısında yer alan borçluların hangi durumlarda bir sözleşme çerçevesinde müteselsil olarak borçlu olabileceği ele alınacaktır. Ardından 6098 sayılı Türk Borçlar Kanunu'nun ${ }^{6}$ sistematiği çerçevesinde borçlu temerrüdünün şartları bakımından müteselsil borçluların durumu ele alınacaktır.

\section{Müteselsil Borç İlişkisinin Tanımı, Özellikleri ve Hukuki Niteliği}

\section{A. Müteselsil Borç İlişkisinin Tanımı ve Özellikleri}

Müteselsil borç ilişkisi, birden çok borçlunun, bir veya birden çok alacakliya karşı, edimin tamamından sorumlu bulunduğu ve borçlulardan birinin yahut birkaçının borcu ifası sonucunda, ifa edilen miktar kadar diğerlerinin de borçtan kurtulduğu borç ilişkisine verilen addır'. TBK' da müteselsil borçluluk m 162 vd.'da düzenlenmiştir. TBK' da müteselsil borçluluğun açık bir tanımı yapılmış olmasa da müteselsil borçluluğu düzenleyen maddelerde müteselsil borçluluğun unsurlarına yer verilmiştir.

Müteselsil borçluluğun özellikleri ele alındığında ilk olarak belirtilebilecek husus müteselsil borçlulukta her bir borçlunun borcun tamamından sorumlu oluşudur ${ }^{8}$.

R.G., T. 04.02.2012, S. 27836.

Oğuzman and Öz, Borçlar Hukuku Genel Hükümler C. 2 (n 5) para. 1339. Benzer tanımlar için bkz. Turgut Akıntürk, Müteselsil Borçluluk (AÜHF Yayınları 1971) 35; Eren (n 1) 1228; Selahattin S Tekinay, Borçlular Arasında Akdi Teselsül, (Yayımlanmamış Doçentlik Tezi) (1956) 30; Tekinay and others (n 2) 285; Feyzi N Feyzioğlu, Borçlar Hukuku Genel Hükümler, C. 2 (2nd edn, İÜHF Yayınları 1977) 302 and 311; Hatemi and Gökyayla (n 1), §36, para. 1; İnan and Yücel (n 1) 544; Murat Canyürek, Müteselsil Borçlulukta İç ve Dış İlişkiler (Vedat Kitapçılık 2003) 11; Ali Bozer, Borçlar Hukuku Genel Hükümler (2nd edn, Banka ve Ticaret Hukuku Araştırma Enstitüsü 2007) 294; Ayşenur Şahin Caner, Türk Borçlar Kanununda Müteselsil Borçluluk (On İki Levha 2017) 12; Hüseyin A Göktürk, Borçlar Hukuku, Birinci Kısım, Borçların Umumi Hükümleri (1946) 51; Tunçomağ (n 4) 1034; Fritz Funk, Borçlar Kanunu Şerhi I Umumi Hükümler (Üniversite Kitabevi n.d) 210; Hıfzı V Velidedeoğlu and Refet. Özdemir, Türk Borçlar Kanunu Şerhi (Genel-Özel) (Yargıtay Yayınları 1987) 309; Mustafa R Karahasan, Türk Borçlar Hukuku Genel Hükümler, C. 2 (Beta 2003) 1329 and 1330; Çiğdem Kırca, 'Müteselsil Sorumlulukta Borçlar Kanunu Tasarısı ile Getirilen Değişiklikler', Prof. Dr. Fikret Eren'e Armağan (Yetkin 2006) 641, 642; Ayșe Arat, 'Müteselsil Borçlarda Alacaklı ile Borçlular Arasındaki İlişkinin Hüküm ve Sonuçları' (2018) 26(2) SÜHFD 325 326-327; Reisoğlu (n 4) 442; Bruno v Büren, Schweizerisches Obligationenrecht Allgemeiner Teil (Schultess \& Co 1964) 90; Max Keller and Schöbi Christian, Das Schweizerische Schuldrecht, B. 4, Gemeinsame Rechtsinstitute für Schuldverhältnisse aus Vertrag, unerlaubter Handlung und ungerechtfertigter Bereicherung (2nd edn, Helbing Lichtenhahn 1985) 5; Stephan Mazan, 'Art. 143-150 OR' in Andreas Furrer and Anton K Schnyder (eds), Handkommentar zum Schweizer Privatrecht Obligationenrecht Allgemeine Bestimmungen (3rd edn. Schulthess 2016), Art. 143, para. 2; Alfred Koller, Schweizerisches Obligationenrecht Allgemeiner Teil (4th edn, Stämpfli 2017) para. 75.01; Frédéric Krauskopf, Art. 143-150 OR, Die Solidarität (Zürcher Kommentar Obligationenrecht, 3rd edn, Schulthess 2016), Art. 143, para. 2; Thomas Müller, 'Art. 143-150 OR' in Jolanta Kren Kostkiewicz and others (eds), OR Kommentar, Schweizerisches Obligationenrecht (3. . $^{\text {th }}$ edn. Orell Füssli 2016) Art. 143, para. 1; Christoph K. Graber, 'Art. 143-150' in Heinrich Honsell, Nedim P Vogt and Wolfgang Wiegand (eds), Basler Kommentar, Obligationenrecht I, Art. 1-529 OR (6 ${ }^{\text {th }}$ edn. Helbing Lichtenhahn Verlag 2015), Art. 143, para. 1; Andreas von Tuhr and Arnold Escher, Allgemeiner Teil des Schweizerischen Obligationenrechts, B. II. (3rd edn, Schulthess 1984) 297; Berger (n 5) para. 2400; Weiss (n 3 ) 15.

Akıntürk (n 7) 36; Tekinay, Borçlular Arasında Akdi Teselsül, (Yayımlanmamış Doçentlik Tezi) (n 7) 78; Eren (n 1) 1229; Oğuzman and Öz, Borçlar Hukuku Genel Hükümler C. 2 (n 5) para. 1345; Tekinay and others (n 2) 285; Ahmet İyimaya, 'Zincirleme Sorumlulardan Yalnızca Biri Aleyhine Açılan Davada 'Zincirleme Sorumluluk Kaydı'nın Yeralması Zorunlu Mudur?' [1995] TBBD 378, 380; Hatemi and Gökyayla (n 1), §36, para. 9; Canyürek (n 7) 13; Ferhat Canbolat, 'Müteselsil Borcun Sona Erme Nedenleri: Borçlar Kanunu Tasarısı'ndaki İlgili Hükümlerin Kısa Değerlendirilmesi ile Birlikte' (Yaz 
Bu husus TBK m 162'de “Birden çok borçludan her biri, alacaklıya karşı borcun tamamından sorumlu olmayı kabul ettiğini bildirirse, müteselsil borçluluk doğar" denilmek suretiyle düzenlenmiştir. Buna bağlı olarak alacaklı dilediği borçluya ifa için başvurabilme imkânına sahiptir. Alacaklı dilediği bir borçludan edimin tamamını talep edebileceği gibi birden fazla borçludan ya da borçluların tamamından da talepte bulunabilir ${ }^{10}$. Bunun yanı sıra alacaklının müteselsil borçlulardan edimin tamamının ifasını isteme zorunluluğu da bulunmayıp, edimin kısmen ifasını istemesi de mümkündür11. Bu hususlar da TBK m 163'te "Alacakl, borcun tamamının veya bir kısmının ifasını, dilerse borçluların hepsinden, dilerse yalnız birinden isteyebilir" şeklinde ifade edilmiştir. Borcun tamamen ifasına kadar bütün borçluların sorumluluğu devam ettiği için kısmen ifa halinde kalan kısım için başka bir borçlunun veya bütün borçluların da takibi mümkündür ${ }^{12}$. Kural olarak borç ifa edilmedikçe dava açılması veya ifaya hükmedilmesi müteselsil borcu sona erdirmez ${ }^{13}$. Bu noktada müteselsil borçluluğun arz ettiği bir diğer özellik olan alacaklının tatmin edilmesiyle diğer borçluların alacaklıya karşı borçtan kurtulmasına ${ }^{14}$ dikkat edilmelidir. Söz konusu

2008) 66(3) ABD 68, 69; Keller and Schöbi Christian, Das Schweizerische Schuldrecht, B. 4, Gemeinsame Rechtsinstitute für Schuldverhältnisse aus Vertrag, unerlaubter Handlung und ungerechtfertigter Bereicherung (n 7) 6; Şahin Caner (n 7) 46; Senai Olgaç, Kazai ve İlmi Iç̧tihatlarla Türk Borçlar Kanunu Genel Hükümler (3rd edn, İsmail Akgün Matbaası 1970) 1041; Lütfü Dalamanl, Faruk Kazancı and Muharrem Kazanc1, İlmi ve Kazai İçtihatlarla Açıklamalı Borçlar Kanunu C. 2 (Kazancı 1990) 676; Ekrem Edgü, Borçlar Hukuku Umumi Hükümler (İ.İ.T.İ.A Nihat Sayar Yayın ve Yardım Vakfı 1978) 107; Büren (n 7) 94; Schwenzer (n 4) para. 88.18; Alain Gautschi, Solidarschuld und Ausgleich (Dike 2009) para. 11; Berger (n 5) para. 2414; Weiss (n 3), 11; Müller (n 7), Art. 144, para. 1; Hans Brox and Walker Wolf-Dietrich, Allgemeines Schuldrecht (39th edn, C.H. Beck 2015), §37, para. 8.

9 Akıntürk (n 7), 38; Oğuzman and Öz, Borçlar Hukuku Genel Hükümler C. 2 (n 5) para. 1344; Hatemi and Gökyayla (n 1), §36, para. 10; Canyürek (n 7) 13; Tekinay and others (n 2) 285; Ahmet H Dağdelen, 818 ve 6098 Sayılı Borçlar Kanunlarında Borçlular Arasında Teselsül (On İki Levha 2011) 80; Şahin Caner (n 7) 43; Arat (n 7) 332; Tunçomağ (n 4) 1041; Ahmet Kılıçoğlu, Borçlar Hukuku Genel Hükümler (22nd edn, Turhan 2018) 949; Peter Gauch, Walter R Schluep and Susan Emmenegger, Schweizerisches Obligationenrecht, Allgemeiner Teil, B. 2 (10th edn, Schulthess 2014) para. 3708; Bucher (n 4) 491; Schwenzer (n 4) para. 88.18; Brigitta Kratz, Obligationenrecht, Solidarität, Art. 143-150 OR (Berner Kommentar Kommentar zum schweizerischen Privatrecht, Stämpfli 2015), Art. 144, para. 12; Kramer and Probst (n 3) para. 547; Peter Jung, 'Art. 143-150' in Heinrich Honsell (ed), Kurzkommentar OR (Helbing Lichtenhahn 2014), Art. 144, para. 1; Theo Guhl, Das Schweizerische Obligationenrecht : mit Einschluss des Handels- und Wertpapierrechts (9th edn, Schulthess 2000), §6, para. 17; Hermann Becker, Berner Kommentar,B. VI, Obligationenrecht Allgemeine Bestimmungen, Art. 1-183 OR (2nd edn, Stämpfli 1945), Art. 144, para. 1; Karl Larenz, Lehrbuch des Schuldrechts, B. 1, Allgemeiner Teil (14th edn, C.H. Beck 1987) 637. Ayrıca bkz. Dağdelen (n 9) 84.

10 Bkz. Akıntürk (n 7) 38; Kılıçoğlu (n 9) 949; Oser and Schönenberger (n 5) 907-908; Ferit H Saymen and Halit K Elbir, Türk Borçlar Hukuku I, Umumi Hükümler C. 2 (İsmail Akgün Matbaası 1958) 784; Hatemi and Gökyayla (n 1), §36, para. 14; İnan and Yücel (n 1) 546; Şahin Caner (n 7) 45; Kapancı (n 5) 143; Bozer (n 7) 296; Edgü (n 8) 107-108; Funk (n 7) 212; Selahattin S Tekinay, 'Müteselsil Borç ile Kefalet Arasında Bir Mukayese' (1956) 47(7) Adalet Dergisi 742, 750; İyimaya (n 8) 380; Mazan (n 7), Art. 143, para. 3; Gauch, Schluep and Emmenegger (n 9) para. 3708; Fikentscher and Heinemann (n 3) para. 771; Brox and Walker Wolf-Dietrich (n 8), §37, para. 12; Krauskopf (n 7), Art. 143, para. 41 ve Art. 144, para. 5; Müller (n 7), Art. 144, para. 1; Graber (n 7), Art. 144, para. 1.

11 Akıntürk (n 7) 37; Tekinay, Borçlular Arasında Akdi Teselsül, (Yayımlanmamış Doçentlik Tezi) (n 7) 78; Bucher (n 4) 494; Krauskopf (n 7), Art. 143, para. 41; Tuhr and Escher (n 7) 305; Müller (n 7), Art. 144, para. 1; Kratz (n 9), Art. 144, para. 16.

12 Akıntürk (n 7) 39. Ayrıca bkz. Guhl (n 9), §6, para. 17; Krauskopf (n 7), Art. 143, para. 39; Keller and Schöbi Christian, Das Schweizerische Schuldrecht, B. 4, Gemeinsame Rechtsinstitute für Schuldverhältnisse aus Vertrag, unerlaubter Handlung und ungerechtfertigter Bereicherung (n 7) 8.

13 Funk (n 7) 212; Velidedeoğlu and Özdemir (n 7) 312; Oser and Schönenberger (n 5) 908; Esat Arsebük, Borçlar Hukuku C. I ve C. 2 (3rd edn, Güney Matbaacılık ve Gazetecilik 1950) 1012; Turgut Önen, Borçlar Hukuku Genel Hükümler (5th edn, Yargı 1999) 108; Gautschi (n 8) para. 22; Krauskopf (n 7), Art. 144, para. 132. Kararlaştırılması kaydıyla bunun mümkün olduğu yönünde bkz. Funk (n 7) 212; Velidedeoğlu and Özdemir (n 7) 312.

14 Akıntürk (n 7) 40; Canyürek (n 7) 16; Tekinay and others (n 2) 288; İyimaya (n 8) 380; Saymen and Elbir (n 10) 780; Canbolat (n 8) 69; Büren (n 7) 95; Mazan (n 7), Art. 143, para. 2; Koller (n 7) para. 75.96; Gauch, Schluep and Emmenegger (n 9) para. 3716; Gautschi (n 8) para. 12 and para. 23; Huguenin (n 3) para. 2297; Guhl (n 9), §6, para. 17; Krauskopf (n 7) 
husus da TBK m 163/f. 2'de "Borçluların sorumluluğu, borcun tamamı ödeninceye kadar devam eder" ve TBK m 166/f. 1'de "Borçlulardan biri, ifa veya takasla borcun tamamını veya bir kısmını sona erdirmişse, bu oranda diğer borçluları da borçtan kurtarmış olur" şeklinde ifadesini bulmuştur. Alacaklı eğer borçlulardan biri tarafindan tatmin edilmiş ise, artık onun diğer borçlulara başvurma imkânı mevcut olmaz $^{15}$. Bunun dışında borçluların kendi içlerinde mevcut borcun ne şekilde taksim edileceğini kararlaştırmalarının, borçluların alacaklı karşısındaki durumları açısından herhangi bir önemi yoktur ${ }^{16}$. Borçlunun alacaklıya karşı kararlaştırılan bu taksimi ileri sürmek suretiyle ifadan kaçınması mümkün değildir ${ }^{17}$.

\section{B. Müteselsil Borç İlişkisinin Hukuki Niteliği}

Müteselsil borçluluğun hukuki niteliği ele alındığında başlıca iki teorinin var olduğu görülür. Bunlardan ilki borcun tekliği teorisis ${ }^{18}$ (Einheitstheorie) olarak adlandırılır. Söz konusu teorinin temelinde "borcun konusunda birlik-hukuki bağlarda çokluk" düşüncesi yer alır ${ }^{19}$. Bu teoriye göre, tek bir borç ilişkisi bulunup bu borç ilişkisinin pasif tarafında birden fazla kişi yer alır ${ }^{20}$. Bu teori uyarınca her bir müteselsil borçlu alacaklıya karşı aynı edimi ifa yükümlülüğü altındadır ${ }^{21}$. Teklik görüşündeki hukuki bağlarda çokluk fikrine göre, borçluların borcunun aynı şey olması, alacaklı ile borçlular arasında birden çok bağ kurulmasına engel teşkil etmez ve borçluların taahhütlerinin belirli oranda bağımsızlık arz eder ${ }^{22}$. Buna göre borçlular alacaklıya karşı aynı edimi borçlanmış olsalar da alacaklıya aynı hukuki bağ ile bağlanmayabilirler; borçluların alacaklıya taahhüt ettikleri edim aynı olsa dahi örneğin ifa yeri veya muacceliyet tarihi gibi taahhütlerinin içerikleri farklılaşabilir23.

Vorbem. Art. 144-147, para. 2 ve Art. 144, para. 130; Tuhr and Escher (n 7) 309; Berger (n 5) para. 2426; Kramer and Probst (n 3) para. 547; Weiss (n 3) 13-14; Schwenzer (n 4) para. 88.24; Müller (n 7), Art. 147, para. 1; Andreas Furrer and Markus Müller-Chen, Obligationenrecht, Allgemeiner Teil (3rd edn, Schulthess 2018) 280; Graber (n 7), Art. 144, para. 7; Jung (n 9), Art. 147, para. 2 Brox and Walker Wolf-Dietrich (n 8), §37, para. 13; Dieter Medicus and Stephan Lorenz, Schuldrecht I, Allgemeiner Teil (21st edn, Beck 2015) para. 887.

15 Eren (n 1) 1230.

16 Oğuzman and Öz, Borçlar Hukuku Genel Hükümler C. 2 (n 5) para. 1345; Arat (n 7) 329. Benzer şekilde bkz. Kratz (n 9), Art. 144, para. 13.

17 Şahin Caner (n 7) 44; Kratz (n 9), Art. 144, para. 16. Bucher (n 4) 491. Ayrıca bkz. Karahasan (n 7) 1331; Weiss (n 3 ) 13.

18 Bu teoriyi savunan yazarlar için bkz. Akıntürk (n 7) “48ff”; Kapancı (n 5) 27, fn. 108. Bu teorinin eleştirisi için bkz. Tekinay, Borçlular Arasında Akdi Teselsül, (Yayımlanmamış Doçentlik Tezi) (n 7) "15ff”.

19 Akıntürk (n 7) 48; Tekinay, Borçlular Arasında Akdi Teselsül, (Yayımlanmamış Doçentlik Tezi) (n 7) 13; Dağdelen (n 9) 11; Şahin Caner (n 7) 37; Tekinay and others (n 2) 288; Kapanc1 (n 5) 27, fn. 108.

20 Oğuzman and Öz, Borçlar Hukuku Genel Hükümler C. 2 (n 5) para. 1340. Ayrıca bkz. Canyürek (n 7) 11-12.

${ }_{21}$ Akıntürk (n 7) 48; Tekinay and others (n 2) 288; Feyzioğlu (n 7) 308; Tekinay, Borçlular Arasında Akdi Teselsül, (Yayımlanmamış Doçentlik Tezi) (n 7) 13; Kırca (n 7) 643, fn. 9. Bu görüşte olmak üzere bkz. Göktürk (n 7) 53.

22 Bu konuda bilgi için bkz. Akıntürk (n 7) 49.

23 Dağdelen (n 9) 12. Doktrinde Oğuzman/Öz (Oğuzman and Öz, Borçlar Hukuku Genel Hükümler C. 2 (n 5) para 1340) ve Kapancı (Kapancı (n 5) 28), teklik görüşünün kabul edilmesinin sonucunun borçluların tamamen ve her açıdan (örneğin, ifa yeri, ifa zamanı gibi) aynı hükümlere olması olduğunu ifade etmişlerdir. Ayrıca Kapancı teklik görüşünü savunan yazarların, hukuki bağlarda çokluk fikrini kabulü nedeniyle her bir borçlu bakımından koşullarda değişiklik yapılabileceğini ileri sürdükleri için, teklik görüşünün pek çok yerde çokluk görüşünün benzeştiğini, farkın sadece borçlanılan edimin tek olmasından ibaret kaldığını belirtmiştir (Kapancı (n 5) 28, fn. 112). 
Doktrinde savunulan ve bizim de katıldığımız diğer bir teori ise borcun çokluğu teorisidir (Mehrheitstheorie) $)^{24}$. Bu görüşe göre müteselsil borç ilişkisinde borçlu sayısı kadar dar anlamda borç bulunur ${ }^{25}$. Bu birden çok borç ilişkisi alacaklı ile her bir müteselsil borçlu arasında ayrı ayrı meydana gelir ${ }^{26}$. Alacaklı ile borçlu arasında meydana gelen bu borç ilişkilerinden her biri, diğerinden az veya çok bağımsız olur ${ }^{27}$. $\mathrm{Bu}$ görüşün bir sonucu olarak her bir borçlu, müteselsil bir borç ilişkisi içerisinde farklı hükümlere göre sorumlu olabilir ${ }^{28}$. Örneğin, ifa zamanının bazı borçlular açısından diğerinden daha geç, zamanaşımının bazı borçlular açısından daha kısa olması mümkün olabilir² ${ }^{29}$. Bunun gibi bu görüş doğrultusunda taraflar arasındaki edim yükümlülüklerinin aynı olmadığı müteselsil borçların var olduğu da kabul edilir $^{30}$. Bu noktada belirtilmesi gereken diğer bir husus da her ne kadar müteselsil borçlulukta alacaklı ve borçlu arasında ayrı ayrı birden çok borç bulunmakta ise de bu borçların birbirleri ile bağlantı içinde olduklarıdır. Bu bağlantıyı sağlayan da ifa amacındaki aynılıktır ${ }^{31}$. Diğer bir deyişle müteselsil borçluların borçları birbirinden bağımsız ise de her birinin amacı alacaklıya olan borcun ifa edilmesidir.

Başlıca bu iki teorinin dışında Fransız hukuku kaynaklı ve karşılıklı temsil ilişkisi olarak adlandırılabilecek teoriye göre, borçlular tarafindan yapılan veya borçlulara karşı yapılan bir işlemin diğer borçlulara etki etmesi, borçluların birbirlerini temsil etmesi ile olur ${ }^{32}$. Bu görüşe göre, bir borçlunun yapmış olduğu bir işlem diğer borçlular tarafından da yapılmış kabul edilmekte veya bir borçluya yönelik yapılan bir işlem diğerine karşı da yapılmış kabul edilmektedir ${ }^{33}$.

TBK'nın kabul ettiği sistem ele alındığında da borcun çokluğu teorisinin esas alındığ 1 ifade edilmiştir ${ }^{34}$. TBK m 166/f. 2'de düzenlenen bir müteselsil borçlunun borcunun sona erdiği hallerde diğer borçluların borcunun devam edişi; TBK m 160/f. 2'de düzenlenen müteselsil borçlulardan birinin zamanaşımından feragatinin

24 Bu teoriyi savunan yazarlar için bkz. Akıntürk (n 7) 59, fn. 76.

25 Oğuzman and Öz, Borçlar Hukuku Genel Hükümler C. 2 (n 5) para. 1341; Hatemi and Gökyayla (n 1) §36, para. 5; Canyürek (n 7) 12; Kapancı (n 5) 28; Dağdelen (n 9) 14.

26 Akıntürk (n 7) 59; İnan and Yücel (n 1) 545; Dağdelen (n 9) 14; Şahin Caner (n 7) 40; Gautschi (n 8) para. 13; Krauskopf (n 7), Art. 143, para. 6 .

27 Akıntürk (n 7) 59; Canyürek (n 7) 12.

28 Oğuzman and Öz, Borçlar Hukuku Genel Hükümler C. 2 (n 5) para. 1341; Hatemi and Gökyayla (n 1), §36, para. 5; Şahin Caner (n 7) 41.

29 Oğuzman and Öz, Borçlar Hukuku Genel Hükümler C. 2 (n 5) para. 1341.

30 ibid para. 1341; Şahin Caner (n 7) 40; Tekinay and others (n 2) 289; Tuhr and Escher (n 7) 298; Krauskopf (n 7), Art. 143, para. 6.; Müller (n 7), Art. 144, para. 4.

31 Akıntürk (n 7) 67; Canyürek (n 7) 12; Dağdelen (n 9) 15; Kapancı (n 5) 29; Gautschi (n 8) para. 18; Becker (n 9) Vorbem. Art. 143-150, para. 9. Larenz (n 9) 638. Ayrica bkz. Tekinay and others (n 2) 289; Krauskopf (n 7), Art. 143, para. 27; Weiss (n 3) $12-13$.

32 Akıntürk (n 7) 50; Tekinay and others (n 2) 289-290; Kapancı (n 5) 26, fn. 107. Bu teori savunan yazarlar için bkz. Akıntürk (n 7) 50, fn. 50. Bu görüş hakkında bilgi ve eleştirisi için bkz. Tekinay and others (n 2) “289ff”; Akıntürk (n 7) “50ff”; Tekinay, Borçlular Arasında Akdi Teselsül, (Yayımlanmamış Doçentlik Tezi) (n 7) “18ff”; Dağdelen (n 9) “12ff”; Feyzioğlu (n 7) 308.

33 Bkz. Feyzioğlu (n 7) 307.

34 Oğuzman and Öz, Borçlar Hukuku Genel Hükümler C. 2 (n 5) para. 1342; Eren (n 1) 1229. 
diğer borçlulara etki etmeyişi ve TBK m 164'te defilerin farklı düzenlenişi buna örnek olarak gösterilmiştir ${ }^{35}$. Buna karşın TBK m 155/f. 1'de düzenlenen müteselsil borçlulardan birine karşı kesilen zamanaşımın diğerlerine karşı da kesmesi borç ilişkisinin çokluğu görüşü ile bağdaşmadığ da ifade edilmiştir ${ }^{36}$. Bunun gibi TBK m 164'te düzenlenen borcun konusu ve sebebinden kaynaklanan defilerden bütün borçluların yararlanabileceği hükmü ve TBK m 166/f. 1'de düzenlenmiş olan borçlulardan birinin alacaklıyı tatmin ettiği oranda diğer borçluların da borcunu sona erdireceğine dair hükmün de çokluk görüşü ile değil, teklik görüşü ile uyuştuğu doktrinde belirtilmiştir ${ }^{37}$.

\section{Müteselsil Borçluların Sözleşmesel Çerçevede Bir Araya Gelme Şekilleri}

\section{A. Genel Olarak}

Alacaklı ile sözleşme yapmış olan müteselsil borçluların bu sözleşme ilişkisi çerçevesinde temerrüdünden bahsedebilmek için her şeyden önce borçluların bu sözleşme ilişkisi içerisinde müteselsil borçlu olarak yer alması şarttır. Bunun için de TBK'nın müteselsil borçluluğun doğuşuna ilişkin hükümlerinden hangilerinin müteselsil borçluları sözleşmesel çerçevede bir araya getirmeye elverişli olduğunun ele alınması gerekmektedir.

Müteselsil borçluluğun doğuşuna sebebiyet veren haller TBK m 162'de düzenlenmiştir. TBK m 162/f. 1'de “Birden çok borçludan her biri, alacaklıya karşı borcun tamamından sorumlu olmayı kabul ettiğini bildirirse, müteselsil borçluluk doğar" denilmek suretiyle tarafların iradesiyle müteselsil borçluluğun doğabileceği kabul edilmiştir. İlk olarak müteselsil borçluluk hukuki işlemden doğabilecektir ${ }^{38}$. Bu kapsamda müteselsil borçluluk sözleşmeden (müteselsil borçluluğu birlikte kabul etme yoluyla, borca katılma veya sözleşmeye katılma yoluyla) veya tek taraflı hukuki işlemden ${ }^{39}$ kaynaklanabilir ${ }^{40}$.

TBK m 162/f. 2'de ise "Böyle bir bildirim yoksa, müteselsil borçluluk ancak kanunda öngörülen hâllerde doğar" denilmiş ve böylelikle hukuki işlem dışında bir kanun hükmünün mevcudiyeti halinde de müteselsil borçluluk meydana gelebileceği

\footnotetext{
${ }_{5}$ Akıntürk (n 7) 64-65; Kırca (n 7) 644; Şahin Caner (n 7) 42. TBK m 160/f. 2 hükmünü belirtmeksizin aynı yönde bkz. Oğuzman and Öz, Borçlar Hukuku Genel Hükümler C. 2 (n 5) para. 1342.

36 Oğuzman and Öz, Borçlar Hukuku Genel Hükümler C. 2 (n 5) para. 1342; Şahin Caner (n 7) 42.

37 Bkz. Şahin Caner (n 7) 42; Akıntürk (n 7) 65.

38 Bkz. Bozer (n 7) 294; Tunçomağ (n 4) 1036.

39 Örneğin vasiyet ile müteselsil borçluluğun doğabileceği doktrinde kabul edilmektedir. Bkz. Tunçomağ (n 4) 1040; Tekinay, Borçlular Arasında Akdi Teselsül, (Yayımlanmamış Doçentlik Tezi) (n 7) 49-50; Oğuzman and Öz, Borçlar Hukuku Genel Hükümler C. 2 (n 5) para. 1359; Şahin Caner (n 7) 70; Eren (n 1) 1232; Dağdelen (n 9) 22; Becker (n 9), Art. 143, para. 2. Bu halde kanundan doğan bir müteselsil borçluluğun olduğu yönünde bkz. Kratz (n 9), Art. 143, para. 179.

${ }^{40}$ Ayrım için bkz. Oğuzman and Öz, Borçlar Hukuku Genel Hükümler C. 2 (n 5) para. "1348ff”. Ayrıca bkz. Eren (n 1) “1231ff”; Canyürek (n 7) “18ff”; Kapancı (n 5) “49ff”; Kılıçoğlu (n 9) “944ff”; Tekinay, Borçlular Arasında Akdi Teselsül, (Yayımlanmamış Doçentlik Tezi) (n 7) “43ff”.
} 
düzenlenmiştir. TBK ve diğer kanunlarda müteselsil borçluluğun kabul edildiği birçok hüküm bulunmaktadır. Ancak bu hükümlerden bazıları sözleşmesel çerçevede müteselsil borçluluğu meydana getirmeye elverişli iken, diğer bazıları ise buna imkân vermez. Örneğin kanundan doğan bir müteselsil borçluluk hali olan TBK m 61 hükmü haksız fiillerdeki sorumluluğa dair olduğundan bu hüküm sözleşmesel çerçevede bir müteselsil borçluluk hali meydana getirmez.

Aşağıda sözleşmeden ve kanundan doğmak suretiyle sözleşme çerçevesinde müteselsil borçluluğa yol açan düzenlemeler değerlendirilecektir ${ }^{41}$.

\section{B. Sözleşmeden Doğan Müteselsil Borçluluk}

\section{Borçluların Müiteselsil Borçluluğu Birlikte Kabulü}

TBK m 162/f. 1'e göre “Birden çok borçludan her biri, alacakllya karşı borcun tamamından sorumlu olmayı kabul ettiğini bildirirse, müteselsil borçluluk doğar". $\mathrm{Bu}$ hükme göre müteselsil borçluluğun iradi olarak doğabilmesi için borçluların alacakliya borcun tamamından sorumlu olduğunu bildirmeleri gerekmektedir. Borçlular ve alacaklı arasında sözleşmenin yapıldığı esnada borçluların müteselsil olarak sorumlu olacakları kararlaştırılmış ise müteselsil borçluluk sözleşmeden doğmuş olur ${ }^{42}$. Borçluların müteselsil borç altına girme iradesiyle alacaklının bunun kabulüne ilişkin iradesinin birbirine uygun olması gerekir ${ }^{43}$. TBK m 162/f. 1'de yer alan hüküm alacaklının irade açıklamasına gerek olmadığı şeklinde anlaşılmamalıdır ve bu bakımdan alacaklının kabul iradesi gereklidir ${ }^{44}$. Bu şekilde teselsülün gerçekleşmesi kural olarak bir şekle tabi değildir ${ }^{45}$.

Borçlular müteselsil olarak borç altına girme iradelerini açık olarak beyan edebileceği gibi örtülü bir şekilde de ortaya koyabilirler ${ }^{46}$. Sözleşmenin kurulduğu

\footnotetext{
41 Tek taraflı irade beyanı ile sözleşmesel çerçevede müteselsil borçluluğun doğmasının mümkün olmadığı kanaatinde olduğumuzdan bu husus aşağıda ele alınmayacaktır.

42 Oğuzman and Öz, Borçlar Hukuku Genel Hükümler C. 2 (n 5) para. 1349. Benzer yönde bkz. Canyürek (n 7) 18; Koller (n 7), para. 75.14; Furrer and Müller-Chen (n 14) 279.

43 Eren (n 1) 1231; Canyürek (n 7) 19; Gauch, Schluep and Emmenegger (n 9) para. 3703 Gautschi (n 8) para. 77. Müteselsil borçluluğun varlığını alacaklının ispatlaması gerektiğine dair bkz. Krauskopf (n 7), Art. 143, para. 89

44 Kılıçoğlu (n 9) 945; Velidedeoğlu and Özdemir (n 7) 310. Ayrıca bkz. Karahasan (n 7) 1331. Alacaklının kabul beyanının açık olması zorunlu değildir, bkz. Kratz (n 9), Art. 143, para. 165

45 Tekinay, Borçlular Arasında Akdi Teselsül, (Yayımlanmamış Doçentlik Tezi) (n 7) 45; Dağdelen (n 9) 18; Gautschi (n 8) para. 84; Huguenin (n 3) para. 2299; Becker (n 9), Art. 143, para. 1; Krauskopf (n 7), Art. 143, para. 87; Berger (n 5) para. 2411; Weiss (n 3) 41; Kratz (n 9), Art. 143, para. 182. Kanuni ve iradi șekle tabi sözleșmeler bakımından durumun değerlendirilmesi için bkz. Weiss (n 3) "42ff".

46 Eren (n 1) 1231; Oğuzman and Öz, Borçlar Hukuku Genel Hükümler C. 2 (n 5) para. 1351; Tekinay, Borçlular Arasında Akdi Teselsül, (Yayımlanmamış Doçentlik Tezi) (n 7) 45; Feyzioğlu (n 7) 305; Tekinay and others (n 2) 293; Arsebük (n 13) 1007; Oser and Schönenberger (n 5) 906; Saymen and Elbir (n 10) 778; Akıntürk (n 7) 112; Hatemi and Gökyayla (n 1) §36, para. 7; Kapancı (n 5) 49-50; İnan and Yücel (n 1) 54; Tercier, Pichonnaz and Develioğlu (n 2), §33, para. 1620; Dağdelen (n 9) 19; Olgaç (n 8) 1037; Reisoğlu (n 4) 443; Karahasan (n 7) 1331; Dalamanl,, Kazancı and Kazancı (n 8) 668; Gauch, Schluep and Emmenegger (n 9) para. 3703; Bucher (n 4) 493; Gautschi (n 8) para. 84; Huguenin (n 3) para. 2298; Jung (n 9), Art. 143, para. 8. Müteselsil borçluluk iradesinin sözleşmeden açık olarak anlaşılması gerektiği yönünde bkz. Kılıçoğlu (n 9) 945; Yarg. 23. HD, E. 2014/3645, K. 2014/4312 (https://karararama.yargitay.gov.tr/YargitayBilgiBankasilstemciWeb/, E.T. 29.05.2019).
} 
esnada, durumun arz ettiği özellik ve işin niteliği göz önünde bulundurulduğunda, borçluların borcun tamamından sorumlu olmayı kabul ettiklerini düşünmesi, alacaklı açısından haklı görülebiliyor ise müteselsil borçluluğun doğduğu kabul edilmelidir ${ }^{47}$. Doktrinde bu durumlara, ihaleye birlikte katılan kişilerin birlikte pey sürmeleri ${ }^{48}$, bir karı kocanın birlikte kiraya veren ile kira sözleşmesi yapmaları, birlikte uydu anten satın almalar1 ${ }^{49}$ örnek verilmiştir ${ }^{50}$.

\section{Borca Katılma ve Sözleşmeye Katılma}

Taraflar arasında müteselsil borçluluğun, borçlular tarafindan birlikte yapılan aynı işlemden doğma zorunluluğu bulunmaz ${ }^{51}$. Müteselsil borçluluğun, sözleşmenin yapıldığ1 anda doğması zorunlu olmayıp, daha sonra doğması da mümkündür ${ }^{52}$. Gerçekten TBK m 201'de düzenlenen borca katılma ve TBK m 206'da düzenlenen sözleşmeye katılma müesseseleri ile sözleşmesel çerçevede bir müteselsil borçluluğun meydana gelmesi kabul edilmiştir.

TBK m 201/f. 1'de borca katılmanın tanım1 "Borca katılma, mevcut bir borca borçlunun yanında yer almak üzere, katılan ile alacaklı arasında yapılan ve katılanın, borçlu ile birlikte borçtan sorumlu olması sonucunu doğuran bir sözleşmedir" şeklinde yapılmış ve ardından konumuz açısından önem arz eden husus olan müteselsil borçluluğa ilişkin olan hüküm olan TBK m 201/f. 2'de ise “Borca katılan ile borçlu, alacaklıya karşı müteselsilen sorumlu olurlar" denilmek suretiyle borca katılmanın müteselsil borçluluğa vücut vereceği açıkça düzenlenmiştir ${ }^{53}$. Borca katılma yoluyla meydana gelen müteselsil borçluluğu, borçluların müteselsil borçluluğu birlikte kabulünden ayıran yönlerinden biri yukarıda da belirtildiği gibi daha sözleşmenin yapıldığı esnada değil, sonradan bir müteselsil borçluluk meydana getirmesidir. Diğer vurgulanması gereken bir fark da borca katılmada müteselsil borç ilişkisinin temelinde iki farklı sözleşmenin var olmasıdır ${ }^{54}$. İlk borçlunun taraf olduğu sözleşme, borcun konusunu oluşturan edimin içeriğinin ve tabi olduğu hükümlerin kaynağını oluşturmakta, katılma sözleşmesi ise ikinci borçlunun edimi müteselsilen üstlenmesinin dayanağını teşkil etmektedir ${ }^{55}$.

\footnotetext{
47 Oğuzman and Öz, Borçlar Hukuku Genel Hükümler C. 2 (n 5) para. 1352; Şahin Caner (n 7) 74.

48 Eren (n 1) 1231; Velidedeoğlu and Özdemir (n 7) 310; Oğuzman and Öz, Borçlar Hukuku Genel Hükümler C. 2 (n 5) para. 1352 ve orada fn. 169'da belirtilen İsviçre Federal Mahkemesi kararı.

49 Oğuzman and Öz, Borçlar Hukuku Genel Hükümler C. 2 (n 5) para. 1352.

50 Başkaca örnekler için bkz. Krauskopf (n 7), Art. 143, para. 92; Müller (n 7), Art. 143, para. 4; Kratz (n 9), Art. 143, para. 163.

51 Tekinay, Borçlular Arasında Akdi Teselsül, (Yayımlanmamış Doçentlik Tezi) (n 7) 48; Canyürek (n 7) 19-20; Tekinay and others (n 2) 294; Feyzioğlu (n 7) 306; Arsebük (n 13) 1008; Guhl (n 9), §6, para. 10; Tuhr and Escher (n 7) 301.

52 Eren (n 1) 1231; Akıntürk (n 7) 114; Hatemi and Gökyayla (n 1), §36, para.7; Mazan (n 7), Art. 143, para. 13; Gauch, Schluep and Emmenegger (n 9) para. 3705; Huguenin (n 3) para. 2301; Berger (n 5) para. 2410; Weiss (n 3) 47; Schwenzer (n 4) para. 88.16; Kratz (n 9), Art. 143, para. 171; Graber (n 7), Art. 143, para. 5. Benzer şekilde bkz. Gautschi (n 8) para. 113.

53 Borca katılma konusunda bilgi için bkz. Arsebük (n 13) 1008-1009; Eren (n 1) “1283ff”; Oğuzman and Öz, Borçlar Hukuku Genel Hükümler C. 2 (n 5) para. 1875; Gamze Turan Başara, 'Türk Borçlar Kanunuyla Getirilen Yeni Bir Müessese: Borca Katılma' (2014) 63(2) AÜHFD 419 “421ff”.

54 Oğuzman and Öz, Borçlar Hukuku Genel Hükümler C. 2 (n 5) para. 1356; Şahin Caner (n 7) 78.

55 Oğuzman and Öz, Borçlar Hukuku Genel Hükümler C. 2 (n 5) para. 1356.
} 
Tarafların iradesi ile müteselsil borçluluğun meydana gelmesini sağlayacak bir diğer bir müessese TBK m 206 ile kabul edilen sözleşmeye katılma müessesesidir ${ }^{56}$. 6098 sayılı TBK ile kabul edilmiş olan bu düzenleme ile müteselsil borçluluk meydana gelebilir. TBK m 206'ya göre:

"Sözleşmeye katılma, mevcut bir sözleşmeye taraflardan birinin yanında yer almak üzere, katılan ile bu sözleşmenin tarafları arasında yapılan ve katılanın, yanında yer aldığ tarafla birlikte, onun hak ve borçlarına sahip olması sonucunu doğuran bir anlaşmadır.-Anlaşmada aksi kararlaştırılmamışsa, sözleşmeye katılan ile yanında yer aldı̆̆ı taraf, sözleşmenin diğer tarafina karşı müteselsilen alacaklı ve borçlu olurlar. -Sözleşmeye katılmanın geçerliliği, katılma konusu sözleşmenin şekline bağlıdır".

Görüldüğü üzere TBK m 206/f. 1'de sözleşmeye katılmanın tanımı yapıllmış, TBK m 206/f. 2'de sözleşmeye katılmada kural olarak müteselsil alacaklı ve borçluluğun söz konusu olacağı hükme bağlanmış, f. 3 'te ise sözleşmeye katılmanın şekli düzenlenmiştir. Buna göre taraflar sözleşmeye katılmak üzere TBK m 206/f. 1 uyarınca bir anlaşma yaptıklarında, TBK m 206/f. 2 uyarınca sözleşmeye katılanın ve sözleşmeye katılanın yanında yer aldığı tarafın, aksi kararlaştırılmadığı sürece müteselsil olarak borçlu olması söz konusu olmaktadır. Bu durumda bunların borçlarına ilişkin olarak TBK m 162 vd. yer alan müteselsil borçluluğa ilişkin hükümlerin uygulanması söz konusu olur ${ }^{57}$.

Sözleşmeye katılmada da tıpkı borca katılmada olduğu gibi ${ }^{58}$ sonradan gelen bir müteselsil borçluluk hali söz konusu olup, yine tıpkı borca katılmada olduğu üzere müteselsil borç ilişkisinin temelinde iki farklı sözleşmenin olduğu görülür.

\section{Kanundan Doğan Müteselsil Borçluluk}

Müteselsil borçluluk tarafların iradesinden kaynaklanabileceği gibi, kanunda öngörülen hallerde tarafların bu yönde bir iradesi olmasa dahi gerçekleşebilir. TBK m 162/f. 2'de bu husus "Böyle bir bildirim yoksa, müteselsil borçluluk ancak kanunda öngörülen hâllerde doğar" denilmek suretiyle açıkça kabul edilmiştir. Böylelikle müteselsil borçluluğun doğabilmesi sadece borçluların iradesine bırakılmamıştır ${ }^{59}$. Ancak müteselsil borçluluk bir hukuki işlem çerçevesinde meydana gelmiyor ise bunu sağlamak için kanunda buna ilişkin bir hüküm var ise söz konusu olur ${ }^{60}$.

Kanun gereği müteselsil borçluluğun doğuşuna ilişkin gerek TBK'da gerekse diğer kanunlarda birçok düzenleme bulunmaktadır. Bu çok sayıdaki düzenleme

\footnotetext{
Sözleşmeye katılma konusunda bilgi için bkz. K1lıçoğlu (n 9) “1059ff”; Oğuzman and Öz, Borçlar Hukuku Genel Hükümler C. 2 (n 5) para. "1921ff”; Zeynep Bahadır, 'Sözleşmenin Devri ve Sözleşmeye Katılma' (2013) 17(3) Gazi Üniversitesi Hukuk Fakültesi Dergisi 1 "22ff".

57 Oğuzman and Öz, Borçlar Hukuku Genel Hükümler C. 2 (n 5) para. 1925.

58 Sözleşmeye katılmanın borca katılmadan farkları için bkz. Kılıçoğlu (n 9) 1060.

59 Akıntürk (n 7) 119.

${ }^{60}$ Canyürek (n 7) 21. Kanunen teselsülün kabul edilmesinde gözetilmiş olabilecek amaçlar için bkz. Kapancı (n 5) 51.
} 
içerisinde çalışmamız bakımından önem arz edenleri, müteselsil borçluları bir sözleşme çerçevesinde bir araya getirme imkânını sağlayanlarıdır. Zira kanundan kaynaklanan bir müteselsil borçluluk hallerinden de sözleşmesel temelde olan haller mevcuttur ${ }^{61}$. Bu noktadan hareketle eğer kanundan doğan müteselsil borçluluk halleri, taraflar bakımından alacaklı ile bir sözleşmesel ilişki içerisinde sorumluluklarını gerektirmiyor ise bu durumda kanunen müteselsil borçluluğun kabul edildiği bu durumlar, müteselsil borçluların sözleşmeden doğan borcunun ifasında temerrüdü bakımından bir özellik arz etmez. Örneğin TBK $m$ 61 hükmünde haksız fiilden birden fazla kişinin müteselsil sorumluluğu (borçluluğu) düzenlenmiştir. Ancak kanunen kabul edilen bu müteselsil borçluluk hali alacaklı ile borçlular arasındaki sözleşme ilişkisine dair bir muhtevayı haiz değildir.

Sözleşmesel çerçevede tarafların iradesinin müteselsil borçluluk yönünde olmamasına karşın kanun gereği bu sonucun bağlandığ durumlara örnek olarak çeşitli düzenlemeler gösterilebilir. TBK m 382 hükmü bunlardan biridir. Bu hükme göre "Bir şeyi birlikte ödünç alanlar, ondan müteselsilen sorumlu olurlar". Buna göre TBK m 379 uyarınca birden fazla kişi bir şeyi karşılıksız kullanmak için ödünç almış iseler, ödünç alanların iradesi müteselsil olarak borç altına girmek olmasa dahi, bu sözleşme kapsamında müteselsil olarak borçlu olurlar ${ }^{62}$.

Bu konuda verilebilecek diğer bir örnek TBK m 567 hükmüdür. Bu hükme göre de "Bir şeyi birlikte saklamak üzere alanlar, müteselsilen sorumlu olurlar" denilmek suretiyle TBK m 561 uyarınca bir saklama sözleşmesi yapmış olan birden fazla saklayanın müteselsil borçluluğu kabul edilmiştir ${ }^{63}$.

TBK m 638/f. 3'te adi ortaklıklarda kanundan doğan bir müteselsil borçluluk halinin varlığı kabul edilmiştir. Buna göre "Ortaklar, birlikte veya bir temsilci aracılı̆̆ ile, bir üçüncü kişiye karşı, ortakllk ilişkisi çerçevesinde üstlendikleri borçlardan, aksi kararlaştırılmamışsa müteselsilen sorumlu olurlar". Söz konusu hüküm uyarınca ortaklık ilişkisi çerçevesinde adi ortaklar birlikte veya bir temsilci onlar adına üçüncü bir kişi ile bir sözleşme yapmış ise bu durumda kural olarak alacaklı karşısında adi ortakların müteselsil olarak borçlu olduğu kabul edilmiştir. Adi ortakların müteselsil olarak borçlu olmamasının ancak bunun sözleşme yapılırken kararlaştırılması halinde olacağ 1 fikrada ifade edilmiştir ${ }^{64}$.

TBK m 511 hükmü kanun gereği müteselsil borçluluğun mevcut olduğu diğer bir haldir. Söz konusu hüküm birlikte vekalet verenlerin ve vekillerin sorumluluğuna ilişkindir. TBK m 511/f. 1'de "Bir kişiye birlikte vekâlet verenler, vekile karşı

\footnotetext{
${ }^{61}$ Keller and Schöbi Christian, Das Schweizerische Schuldrecht, B. 4, Gemeinsame Rechtsinstitute für Schuldverhältnisse aus Vertrag, unerlaubter Handlung und ungerechtfertigter Bereicherung (n 7) 6.

62 Bkz. Cevdet Yavuz, Faruk Acar and Burak Özen, Türk Borçlar Hukuku Özel Hükümler (10th edn, Beta 2014) 729-730.

63 Bkz. ibid 1378-1379.

${ }^{64}$ Bilgi için bkz. Oruç H Şener, Teorik ve Uygulamalı Ortaklıklar Hukuku (3rd edn, Seçkin 2017) "83ff”"
} 
müteselsil olarak sorumludurlar" denilmek suretiyle vekalet verenler açısından bir müteselsil sorumluluk hali kabul edilmiştir. Benzer şekilde TBK m 511/f. 2'de de durum vekiller açısından "Vekâleti birlikte üstlenenler, vekâletin ifasından müteselsil olarak sorumludurlar ve yetkilerini başkalarına devir hakları olmadıkça, vekâlet vereni, ancak birlikte yaptıkları fiil ve işlemleriyle borç altına sokabilirler" şeklinde düzenlenmiştir. Görüldüğü üzere vekalet sözleşmesinin gerek vekalet veren gerekse vekil tarafında birden fazla borçlunun yer aldığı durumlarda bu kişiler müteselsil borçlu olmaktadır ${ }^{65}$.

$\mathrm{Bu}$ noktada belirtmek istediğimiz diğer bir sözleşmesel çerçevede müteselsil borçluluğa sebep olabilecek ve kanundan doğan hal de TTK m 7/f. 1, c. 1'de düzenlenen ticari işlerdeki teselsül karinesidir. Bu hükme göre "íki veya daha fazla kişi, içlerinden yalnı biri veya hepsi için ticari niteliği haiz bir iş dolaylsıyla, diğer bir kimseye karşı birlikte borç altına girerse, kanunda veya sözleşmede aksi öngörülmemişse müteselsilen sorumlu olurlar". Buna göre taraflar bu noktada sözleşmeyi yaparken aksini kararlaştırmamışlar ise veya müteselsil borçluluğun söz konusu olmayacağını belirten bir hüküm olmadıkça ticari bir işte birden fazla borçlu alacaklıya karşı müteselsil borçlu durumunda olur. Bu noktada tarafların müteselsil borçluluğun doğmaması konusunda bir anlaşma içinde olduklarını ispatlamaları şarttır ${ }^{66}$. Aksi takdirde müteselsil borçluluğun mevcudiyeti kabul edilir.

\section{Müteselsil Borçluların Temerrüdünün Şartları}

\section{A. Genel Olarak}

Borçlu temerrüdünün şartları TBK m 117'de belirtilmiştir. İlgili hükme göre "Muaccel bir borcun borçlusu, alacaklının ihtartyla temerrüde düşer. - Borcun ifa edileceği gün, birlikte belirlenmiş veya sözleşmede sakl tutulan bir hakka dayanarak taraflardan biri usulüne uygun bir bildirimde bulunmak suretiyle belirlemissse, bu günün geçmesiyle; haksız fiilde fiilin işlendiği, sebepsiz zenginleşmede ise zenginleşmenin gerçekleştiği tarihte borçlu temerrüde düşmüs olur. Ancak sebepsiz zenginleşenin iyiniyetli olduğu hâllerde temerrüt için bildirim şarttır". Maddenin ilk fikrasından borçlunun temerrüdü ile ilgili olarak çıkarılan sonuçlar borcun muaccel olması ve alacaklının ihtarda bulunmasıdır. Maddenin ikinci fikrasında ise ihtara gerek olmayan hallere yer verilmiştir.

Temerrüdün şartlarını, borcun muaccel olmasına rağmen ifa edilmemesi; alacaklının ihtarı, borcun ifasının mümkün olması ve alacaklının ifayı kabule hazır

\footnotetext{
65 Söz konusu hükümler hakkında bilgi için bkz. Yavuz, Acar and Özen (n 62) 1213-1213 ve 1217-1218.

66 Oğuzman and Öz, Borçlar Hukuku Genel Hükümler C. 2 (n 5) para. 1354; Arat (n 7) 328.
} 
olması olarak belirtebiliriz ${ }^{67,68}$. Ancak buna geçmeden önce konu ile ilgisi bakımından müteselsil borçlulukta borçlunun kendi davranışı ile diğer borçluların durumunu ağırlaştıramamasına ilişkin TBK m 165 hükmü kısaca ele alınmalıdır. Zira müteselsil borçluların temerrüdü açısından bu hüküm önem arz etmektedir.

Müteselsil borçluların borçları birbirinden bağımsız nitelik arz eder ve buna bağl1 olarak borçluların davranışı sadece kendisi bakımından sonuç doğurur ${ }^{69}$. TBK m 165 hükmü de bu bağımsız oluşun sonucu olan bir hükümdür ${ }^{70}$. Bu hüküm uyarınca "Kanun veya sözleşme ile aksi belirlenmedikçe, borçlulardan biri kendi davranışıyla diğer borçluların durumunu ağırlaştıramaz". Bu kuraldan ortaya birtakım sonuçlar çıkmaktadır Bunlardan biri, borçlulardan birinin faiz ödemek veya kabul edilen faizin miktarını yükseltmek, ceza koşulu ödemek, vadeyi öne almak gibi konularda alacaklı ile anlaşması halinde bunun diğer borçluları bağlamamasıdır ${ }^{71}$. Bu şekilde kendisi bakımından ağırlaştırdığı bir borcu ifa eden müteselsil borçlunun bu ağılaşan kısım için diğer müteselsil borçlulara rücu imkânı bulunmaz ${ }^{72}$. Diğer bir sonuç, borçlulardan biri eğer ortak bir savunmayı yapmayıp, hakkında açılan davanın kaybına sebebiyet vermesi buna bağlı olarak ödeme yapma zorunda kalması durumundan diğer borçluların bundan etkilenmemesidir ${ }^{73}$. Bir diğer sonuç ise borçlulardan birinin borcu ihlal etmesinden sorumluluğun da ihlali yapan borçluya ait olması, diğer borçluları etkilememesidir ${ }^{74}$. Yine bu son kuraldan çıkan ve konumuz açısından önemli olan husus, borçlunun temerrüdü ve sonuçları da her bir borçlu için birbirinden bağımsız ve ayrı sonuç doğurmasıdır ${ }^{75}$.

$\overline{67}$ Bu ayrım için bkz. Oğuzman and Öz, Borçlar Hukuku Genel Hükümler C. 1 (n 2) para. "1501ff”. Oğuzman/Öz, borçlu temerrüdünde kusurun rolünü de temerrüdün şartları başlığı altında ele almış, ancak yazarlar kusurun öneminin temerrüde düşmek bakımından değil, temerrüdün bazı sonuçları açısından önemli olduğunu ifade etmişlerdir, Oğuzman and Öz, Borçlar Hukuku Genel Hükümler C. 1 (n 2) para. 1533. Benzer şekilde bkz. Tekinay and others (n 2) 919. Biz de Oğuzman/ Öz'ün temerrütte kusurun etkisi konusundaki fikrine iștirak etmekle beraber, sistematik olarak karışıklığa yol açmamak gayesiyle çalışmamızda temerrüdün şartları arasında yer vermedik.

68 Doktrinde yapılan başkaca tasnifler için bkz. Eren (n 1) "1120ff”; Kılıçoğlu (n 9) "875ff”; Tekinay and others (n 2) "911ff”; Gauch, Schluep and Emmenegger (n 9) para. “2657ff”.; Schwenzer (n 4), para. “65.01ff”; Max Keller and Schöbi Christian, Keller, Max/Schöbi, Christian, Das Schweizerische Schuldrecht, B. 1, Allgemeine Lehren des Vertragrechts (3rd edn, Helbing Lichtenhahn 1988) "265ff”.

69 Eren (n 1) 1236; Hatemi and Gökyayla (n 1), §36, para.24. Ayrıca bkz. Oser and Schönenberger (n 5) 910; Mazan (n 7), Art. 146, para. 1; Gauch, Schluep and Emmenegger (n 9), para. 3724.

70 Tunçomağ (n 4) 1046; Arsebük (n 13) 1014. Ayrıca bkz. Krauskopf (n 7), Art. 146, para. 1; Keller and Schöbi Christian, Das Schweizerische Schuldrecht, B. 4, Gemeinsame Rechtsinstitute für Schuldverhältnisse aus Vertrag, unerlaubter Handlung und ungerechtfertigter Bereicherung (n 7) 11.

71 Oğuzman and Öz, Borçlar Hukuku Genel Hükümler C. 2 (n 5) para. 1395; Eren (n 1) 1236. Ayrıca bkz. Kapancı (n 5) 153; Hatemi and Gökyayla (n 1), §36, para. 24; Tunçomağ (n 4) 1046; Reisoğlu (n 4) 445; Dalamanlı, Kazancı and Kazancı (n 8) 683; Büren (n 7) 96; Mazan (n 7), Art. 146, para. 2; Gautschi (n 8) para. 15; Huguenin (n 3) para. 2305; Guhl (n 9), §6, para. 19; Tuhr and Escher (n 7) 306-307; Kramer and Probst (n 3) para. 547; Schwenzer (n 4) para. 88.21; Müller (n 7), Art. 146, para. 1; Kratz (n 9), Art. 146, para. 37; Graber (n 7), Art. 146, para. 1; Jung (n 9), Art. 146, para. 1.

72 Kapanc1 (n 5) 154; Erdoğan (n 1) 254; Olgaç (n 8) 1047; Göktürk (n 7) 55

73 Oğuzman and Öz, Borçlar Hukuku Genel Hükümler C. 2 (n 5) para. 1394.

74 Oğuzman and Öz, Borçlar Hukuku Genel Hükümler C. 2 (n 5) para. 1396; Tekinay and others (n 2) 310-311; Koller (n 7), para. 75.56 .

75 Eren (n 1) 1236; Tunçomağ (n 4) 1046. Ayrıca bkz. Şahin Caner (n 7) 244; Kapancı (n 5) 158; Fulya Erlüle, 'Müteselsil Kefalet ve Müteselsil Borçluluk Kavramlarının Karşılaştırılması' (2003) 7(1-2) AÜEHFD 629, 641; Göktürk (n 7) 55; Funk (n 7) 214; Tekinay, 'Müteselsil Borç ile Kefalet Arasında Bir Mukayese' (n 10) 747; Saymen and Elbir (n 10) 786; Velidedeoğlu and Özdemir (n 7) 313-314; Arsebük (n 13) 1015; Mazan (n 7), Art. 146, para. 4; Bucher (n 4) 494-495; 
Müteselsil bir borçlunun diğerinin durumunu ağırlaştıramayacağı kuralı mutlak bir kural değildir. Nitekim TBK m 165 'te bu kuralın aksinin kanunda yer almasının mümkün olduğu veya taraflarca aksinin kararlaştırılabileceği kabul edilmiştir. Buna göre örneğin müteselsil borçlular, aralarından birinin borcu ihlali halinde söz konusu olacak tazminat borcu bakımından müteselsil sorumluluğu kabul edebilirler ${ }^{76}$. Yine eğer taraflar aksini kararlaştırmışlar ise bir borçlunun temerrüdünün sonuçlarından diğer bütün borçluların da müteselsil olarak sorumlu olmaları mümkün olur ${ }^{77}$.

Burada son olarak bahsedilmesi gereken husus alacaklının da tek bir müteselsil borçluya yönelen fiilinin diğerleri açısından bir etkisinin olmamasıdır ${ }^{78}$. Örneğin borçluya karşı yapılan muacceliyete ilişkin ihtarı sadece onun açısından sonuç doğurur ve diğer borçları muaccel kılmaz ${ }^{79}$. Bunun gibi borçluların tamamının borcu muaccel olmuş olsa bile, borçlulardan sadece birine yapılan temerrüt ihtarı, sadece o borçluyu temerrüde düşürür ${ }^{80}$. Kanaatimizce bu husus da mutlak olarak kabul edilmemelidir. TBK m 165 hükmünün kıyasen burada uygulanması mümkün olmalıdır. Buna göre taraflar sözleşme yapılırken eğer bunun aksini kararlaştırmışlar ise bu durumda alacaklının tek bir borçluya karşı yönelen davranışının diğerlerine karşı da sonuç doğurması da kararlaştırılabilmelidir.

\section{B. Borcun Muaccel Olmasına Rağmen İfa Edilmemesi}

TBK m 117'de “Muaccel bir borcun borçlusu, alacaklının ihtarlyla temerrüde düşer" denilmek suretiyle temerrüdün gerçekleşmesi için borcun muaccel olması gerektiği ifade edilmiştir.

Taraflar arasında borç vadeye bağlanmış ise bu borcun muaccel olması için vadenin gelmesi gerekir ${ }^{81}$. Taraflar arasında bir vade kararlaştırılmamış ise TBK m 90 hükmü gereği borç doğduğu anda muaccel olur ${ }^{82}$. Müteselsil borçlulukta, müteselsil borçluların

Gautschi (n 8) para. 14; Furrer and Müller-Chen (n 14) 280; Berger (n 5) para. 2424; Müller (n 7), Art. 146, para. 1; Kratz (n 9), Art. 146, para. 24 ve para. 33; Graber (n 7), Art. 146, para. 2. Alman hukukunda bu konu BGB $\S 425$ 'te bir hüküm yer almaktadır. Buna göre aksi borç ilișkisinden anlașılmadıkça temerrüdün sadece ilgili kişiyi etkileyeceği kabul edilmiștir. Ayrıca bkz. Fikentscher and Heinemann (n 3) para. 775; Brox and Walker Wolf-Dietrich (n 8), §37, para. 14; Larenz (n 9) 639; Medicus and Lorenz (n 14) para. 895. Doktrinde Tekinay genel prensibin bu olduğunun kabul edilmesi gerektiğini belirtmekle birlikte, borçluların iç ilişkisi veya alacaklıya bulundukları taahhüt gereğince, ifa için gerekli işleri birlikte yapmaları gerekiyorsa ya da birbirlerini gözetmeleri gerekiyorsa bu halde tarafların birinin kusuru ile veya temerrüt halinde meydana gelen zarar ve hasardan diğer borçluların sorumluluklarının da devam edeceğini ifade etmektedir. bkz. Tekinay, Borçlular Arasında Akdi Teselsül, (Yayımlanmamış Doçentlik Tezi) (n 7) 128-129.

76 Oğuzman and Öz, Borçlar Hukuku Genel Hükümler C. 2 (n 5) para. 1398.

77 Funk (n 7) 214.

78 Eren (n 1) 1237; Oğuzman and Öz, Borçlar Hukuku Genel Hükümler C. 2 (n 5) para. 1399; Krauskopf (n 7), Art. 146, para 5. Ayrica bkz. Koller (n 7), para. 75.57; Kratz (n 9), Art. 146, para. 10.

79 Eren (n 1) 1237

80 Oğuzman and Öz, Borçlar Hukuku Genel Hükümler C. 2 (n 5) para. 1400.

81 Oğuzman and Öz, Borçlar Hukuku Genel Hükümler C. 1 (n 2) para. 996; Halil Akkanat, 'İfada Gecikme ve Borçlu Temerrüdü', Prof. Dr. M. Kemal Oğuzman'ın Anisına Armağan (Beta 2000) 10.

82 Söz konusu borcun doğumu anının dürüstlük kuralı ışı̆̆ında yorumlanması gerekir ve bu kurala göre borçluya ifa için gereken zaman tanınmalıdır. Bkz. Oğuzman and Öz, Borçlar Hukuku Genel Hükümler C. 1 (n 2) para. 1004; Eren (n 1) 974 Tekinay and others (n 2) 801; Tuhr and Escher (n 7) 50-51; Keller and Schöbi Christian, Keller, Max/Schöbi, Christian, Das Schweizerische Schuldrecht, B. 1, Allgemeine Lehren des Vertragrechts (n 68) 214. Benzer şekilde bkz. Bucher (n 4) 306. 
borçları birbirinden bağımsız nitelikte olduğu için bu borçların muacceliyet ve temerrüt tarihleri birbirinden farklı olabilir ${ }^{83}$. Buna göre çeşitli ayrımlar söz konusu olabilir. Alacaklının müteselsil borçlular ile yapmış olduğu sözleşmede herhangi bir ifa zamanı kararlaştırılmamış olabilir. Bu durumda genel kural uygulama alanı bulur ve TBK m 90 uyarınca bütün borçluların borcu borcun doğumu anında, sözleşmeler açısından sözleşmenin yapılması ile muaccel olur. İkinci ihtimal ise alacaklının müteselsil borçluların her biri ile farklı bir ifa zamanının kararlaştırılmış olmasıdır. Bu durumda da her bir müteselsil borçlu açısından ifa zamanı geldiğinde onun borcunun muaccel olduğundan bahsedilir. Üçüncü ihtimal ise alacaklının borçluların bazıları ile bir ifa zamanının kararlaştıılması, bazıları ile ise böyle bir kararlaştırmada bulunmamış olmasıdır. Bu durumda ise ifa zamanı kararlaştııılmış bulunan müteselsil borçluların borcu belirlenen vade geldiğinde, kararlaştırılmamış olan müteselsil borçluların borcu ise kural olarak sözleşmenin yapılması ile muaccel olur.

Temerrüdün gerçekleşebilmesi için borcun muaccel olmasının yanında, borçluların muacceliyete karşın borcu ifa etmemiş olması da gerekir. Ancak muacceliyete karşın alacaklının ifa talebine karşın borçlunun kullanabileceği bir defi hakkı mevcut ise bu definin kullanımı temerrüdü engeller ${ }^{84}$. Müteselsil borçlulardan birinin alacaklıya karşı örneğin zamanaşımı defi gibi bir defi ileri sürme imkânı var ve bunu da ileri sürmüş ise bu durum onun temerrüdüne engel olur ${ }^{85}$. Benzer şekilde borçlunun alacaklıya karşı ödemezlik defi ${ }^{86}$ ileri sürmesi de temerrüde düşmesini engeller ${ }^{87}$.

Burada ele alınabilecek bir husus da alacaklının müteselsil borçlularla yaptığı tecil anlaşmasının etkisinin ne olacağıdır. Tecil anlaşması sözleşmenin kurulmasından sonra bir borcun vadeye bağlanmasına veya mevcut vadenin uzatılmasına dair anlaşmadır ${ }^{88}$. Bu anlaşma sonucunda alacaklının bu tecil süresi boyunca alacağını talep etmesi mümkün olmaz ${ }^{89}$. Alacaklının müteselsil borçlulardan biri ile veya bazıları ile tecil anlaşması yapmasının diğer borçluların durumunu kötüleştirdiğinden bahsedilebilecek ve alacaklının sorumluluğuna yol açabilecek midir? Zira TBK m 168/f. 2'de alacaklının borçlulardan birinin durumunu diğerlerinin zararına iyileştirmesi halinde bunun sonuçlarına katlanacağı düzenlenmiştir.

\footnotetext{
83 Şahin Caner (n 7) 244. Muacceliyet tarihi bakımından aynı yönde bkz. Tekinay, 'Müteselsil Borç ile Kefalet Arasında Bir Mukayese' (n 10) 748; Erlüle (n 75) 641; Funk (n 7) 212.

84 Oğuzman and Öz, Borçlar Hukuku Genel Hükümler C. 1 (n 2) para. 1504. Ancak sadece defi ileri sürme olanağının varlığ 1 muacceliyeti (ve dolayısıyla temerrüdü) engellemez. Bunun ileri sürülmesi de gerekir. Bkz. Tunçomağ (n 4) 905; Feyzioğlu (n 7) 231; Reisoğlu (n 4) 369; Akkanat (n 81) 43; Tuhr and Escher (n 7) 136; Cüneyt Pekmez, Borcun Ifa Edilmediği Defi (Ödemezlik Defi) (On İki Levha 2019) 422. Bu konudaki tartışmalar için bkz. Pekmez (n 84) "410ff”; Salamon Kaniti, Akdin İfa Edilmediği Def'i (İ̈HF Yayınları 1962) 154-155.

85 Zamanaşımı def'i hakkında bilgi için bkz. Mehmet Erdem, Özel Hukukta Zamanaşımı (1st edn, On İki Levha 2010) "350ff”; Meliha S Paksoy, Zamanaşımından Feragat (TBK 160) (1st edn, On İki Levha 2012), "36ff”.

86 Ödemezlik defi hakkında bilgi için bkz. Kaniti (n 84) "4ff”; Pekmez (n 84) "5ff”.

87 Bkz. Kaniti (n 84) 155.

88 Bkz. Oğuzman and Öz, Borçlar Hukuku Genel Hükümler C. 1 (n 2) para. 1006; Akkanat (n 81) 11. Bilgi için bkz. Melek B Yüce, Alacaklı ve Borçlu Açısından Ifa Zamanı (Vedat Kitapçılık 2015) "256ff”.

89 Oğuzman and Öz, Borçlar Hukuku Genel Hükümler C. 1 (n 2) para. 1007. Bu anlaşmanın başkaca sonuçları için bkz. Yüce (n 88) “263ff".
} 
Gerçekten de alacaklı müteselsil bir borçlu ile bir tecil anlaşması yaptığında, onun durumunu iyileştirmektedir. Bunu, o kişiye borcunu ifa etme konusunda firsat tanımak ve özellikle temerrüde düşmesini önleyerek temerrüdün olumsuz sonuçlarından onu korumak suretiyle yapmaktadır. Ancak bu noktada bakılması gereken ikinci unsur TBK m 168/f. 2'de belirtilen bu iyileştirmenin diğer müteselsil borçluların zararına olup olmadığıdır. Zira her ne kadar müteselsil borçlunun durumu iyileştirilmiş olsa da diğer borçlular bundan olumsuz etkilenmiyor ise bu durumda alacaklının sorumluluğundan bahsedilemez. Her bir borçlunun borcun tamamını ödemekle yükümlü olduğu müteselsil borçlulukta borçluların zarar gördüğünden, ancak borcun ifasından sonra bunların rücu imkânının ortadan kalkması veya azalması halinde bahsedilebilir ${ }^{90}$. Bu da alacaklı tarafindan bir borçlu tarafından verilen kefalet veya rehin gibi teminatların kaldırılması halinde, ifa eden borçlunun halefiyet gereği bu imkânlardan yararlanamaması durumunda söz konusu olur ${ }^{91}$. Ancak tecil anlaşmasında bu şekilde bir durum ile karşılaşılmaz. Tecil anlaşması yapıldı̆̆ında söz konusu olan müteselsil borçlunun borcunun muacceliyetinin bir süre daha ertelenmesi söz konusudur. Muacceliyet her ne kadar ertelenmiş olsa da borçlu halen borcun tamamından sorumludur. Diğer bir müteselsil borçlu kendi borcu muaccel olduğu için ifada bulunur ise sonrasında yine tecil anlaşmasını yapmış olan borçluya da rücu edebilir. Bu noktada diğer borçluların bir zararının varlığından bahsedilemez ${ }^{92}$.

Aksine bazı durumlarda ise yapılan alacaklının müteselsil borçlulardan biri ile yapmış olduğu tecil anlaşmasının diğer müteselsil borçluların yararına olması mümkündür. Şöyle ki, yukarıda da belirtildiği üzere ${ }^{93}$ TBK m 165 hükmü çerçevesinde borçlulardan birinin temerrüdünün sonuçlarından diğer borçluların da müteselsil olarak sorumlu olacaklarını tarafların kararlaştırmaları mümkündür. Böyle bir durumda müteselsil borçlulardan birinin alacaklı ile bir tecil anlaşması yapmak suretiyle temerrüde düşmekten kurtulması, bazı durumlarda diğer borçluları bu anlaşma yapılmasaydı düşülecek temerrüdün gerçekleşecek olumsuz sonuçlarından da kurtarabilir. Örneğin, müteselsil borçlulardan biri alacaklı ile yapmış olduğu tecil anlaşması ile borcunun ifa zamanını üç ay ileriye atmış olsun. Bu halde tecil anlaşması yapılmasa idi bu borçlunun üç ay sonra temerrüde düşmesi ile, başlangıçta yapılan ve temerrüdün gerçekleşmesi halinde diğer müteselsil borçluların da tek bir borçlunun temerrüdünün sonuçlarından da sorumlu olacaklarına dair önceden yapılan anlaşma gereğince, sorumluluklarının meydana gelmesi söz konusu olacaktı. Ancak söz konusu borçlunun alacaklı ile yapmış olduğu tecil anlaşması gereğince temerrüde düşmekten kurtulması, dolaylı olarak diğer müteselsil borçluların da yararına sonuçlar meydana getirmiş olur.

\footnotetext{
90 Canyürek (n 7) 34; Şahin Caner (n 7) 201; Akıntürk (n 7) 159-160; Tekinay and others (n 2) 321; Arat (n 7 ) 337.

91 Canyürek (n 7) 34.

92 Müteselsil borçlulardan biri ile tecil anlaşması yapılmasının ardından, borcu daha önce muaccel olan ve temerrüde düşen diğer müteselsil borçlunun temerrüdü nedeniyle gecikme tazminatı ödemek zorunda kalmasının, alacaklının borçlunun durumunu ağırlaştırması olarak anlaşılıp anlaşılmayacağı hususunda bkz. fn. 138.

93 Bkz. IV. A.
} 


\section{Alacaklının İhtarı}

Borcun muaccel olması üzerine alacaklı kendiliğinden temerrüde düşmez TBK m 117 'de de belirtildiği üzere temerrüt sonucunun gerçekleşebilmesi için alacaklının kural olarak borçluya ihtarda bulunması gerekir. İhtar borçluya yöneltilen bir irade beyanı olup, alacaklı bununla borçludan borcun ifasını ister ${ }^{94}$. İhtar hukuki işlem benzeri bir fiil teşkil eder ${ }^{95}$. Zira borçlunun ihtarı teşkil eden beyanda bulunduğu esnada borçluyu temerrüde düşürme isteğinin olup olmadığı önem arz etmez ${ }^{96}$. Bunun dişında kural olarak ihtar herhangi bir şekil şartına bağlı değildir ${ }^{97}$. Ancak tacirler arasında temerrüde düşürmeye ilişkin ihtarların TTK m 18/f. 3 uyarınca noter aracılığı ile, taahhütlü mektup ile, telgrafla veya güvenli elektronik imza kullanılarak kayıtlı elektronik posta sistemi kullanılarak yapılması gerekir ${ }^{98}$.

TBK m 117/f. 2'de belirtilen bazı durumlarda sözleşmeler açısından ihtara gerek olmaksızın temerrüt gerçekleşir. Buna göre, borcun ifa edileceği gün birlikte belirlenmiş ise veya sözleşmede saklı tutulan bir hak uyarınca sözleşme taraflarından biri tarafindan usulüne uygun bir bildirim sonucunda belirlenmişse, temerrüdün gerçekleşmesi için ihtara gerek yoktur. Bunun yanı sıra dürüstlük kuralı gereğince bir ihtarın yapılması beklenemeyecek ise bu durumda da temerrüdün ihtarsız olarak gerçekleşeceği kabul edilmektedir ${ }^{99}$. Borçlunun borcunu ifa etmeyeceğini açık bir şekilde beyan etmesi ${ }^{100}$ veya ifayı gerçekleştirmesi gerektiği zamanı alacaklının değil de borçlunun bilmesi ${ }^{101}$ halleri böyledir.

94 Oğuzman and Öz, Borçlar Hukuku Genel Hükümler C. 1 (n 2) para. 1508; Tunçomağ (n 4) 906; Eren (n 1) 1121; Büren (n 7) 367; Tuhr and Escher (n 7) 136; Keller and Schöbi Christian, Keller, Max/Schöbi, Christian, Das Schweizerische Schuldrecht, B. 1, Allgemeine Lehren des Vertragrechts (n 68) 266.

95 Oğuzman and Öz, Borçlar Hukuku Genel Hükümler C. 1 (n 2) para. 1508; Hatemi and Gökyayla (n 1), §26, para. 61; Kılıçoğlu (n 9) 876; Eren (n 1) 1121; Kocayusufpaşaoğlu and others (n 1), §9, para. 6; İnan and Yücel (n 1) 618; Tercier, Pichonnaz and Develioğlu (n 2), §25, para. 1283; Tekinay and others (n 2) 914; Akkanat (n 81) 21; Tuhr and Escher (n 7) 136; Schwenzer (n 4) para. 65.08; Bucher (n 4) 358; Keller and Schöbi Christian, Keller, Max/Schöbi, Christian, Das Schweizerische Schuldrecht, B. 1, Allgemeine Lehren des Vertragrechts (n 68) 266.

96 Hatemi and Gökyayla (n 1), §26, para. 61; Oğuzman and Öz, Borçlar Hukuku Genel Hükümler C. 1 (n 2) para. 1508; Kocayusufpaşaoğlu and others (n 1), §9, para. 6; Tuhr and Escher (n 7) 136.

97 Kılıçoğlu (n 9) 876; Tunçomağ (n 4) 906; Oğuzman and Öz, Borçlar Hukuku Genel Hükümler C. 1 (n 2) para. 1512; İnan and Yücel (n 1) 618; Tercier, Pichonnaz and Develioğlu (n 2), §25, para. 1283; Erdoğan (n 1) 219; Göktürk (n 7) 261; Feyzioğlu (n 7) 232; Saymen and Elbir (n 10) 737; Eren (n 1) 1122; Akkanat (n 81) 26-27; Tuhr and Escher (n 7) 136; Tekinay and others (n 2) 914; Edgü (n 8)139; Gauch, Schluep and Emmenegger (n 9) para. 2704; Furrer and Müller-Chen (n 14) 599; Keller and Schöbi Christian, Keller, Max/Schöbi, Christian, Das Schweizerische Schuldrecht, B. 1, Allgemeine Lehren des Vertragrechts (n 68) 266.

98 Bu hükümde öngörülen şekil şartının niteliği hususundaki tartışmalar için bkz. Tülay Aydın Ünver, 'Tacirler Arası İhbar ve İhtarlara İlişkin Şeklin Hukuki Niteliği', Prof. Dr. Hasan Erman'a Armağan (Der 2015) “861ff”. Şekil şartına ilişkin olarak kabul edilen hukuki niteliğin sonuçlarının ne olacağı hususunda bilgi için bkz. Nil Karabağ Bulut, 'Tacirler Arası İhbar ve İhtarlar Bakımından Getirilen Şeklin Geçerlilik Veya İspat Şartı Şeklinde Nitelendirilmesine Bağlı Olarak Doğuracağı Hukuki Sonuçlar', Prof. Dr. Hasan Erman'a Armağan (Der 2015) " $231 \mathrm{ff”.}$

99 Oğuzman and Öz, Borçlar Hukuku Genel Hükümler C. 1 (n 2) para. 1525; Tekinay and others (n 2) 918; Akkanat (n 81$) 37$.

100 Tekinay and others (n 2) 918; Tunçomağ (n 4) 911; Göktürk (n 7) 261; Eren (n 1) 1125; K1lıçoğlu (n 9) 881; İnan and Yücel (n 1) 620; Akkanat (n 81) 39; Tercier, Pichonnaz and Develioğlu (n 2), §25, para. 1286; Erdoğan (n 1) 220; Edgü (n 8) 139; Feyzioğlu (n 7) 237-238; Tuhr and Escher (n 7) 141; Kramer and Probst (n 3) para. 491.

101 Tunçomağ (n 4) 911; Oğuzman and Öz, Borçlar Hukuku Genel Hükümler C. 1 (n 2) para. 1525; Tekinay and others (n 2). 918; Feyzioğlu (n 7) 238; İnan and Yücel (n 1) 619; Akkanat (n 81) 37; Tuhr and Escher (n 7) 140. 
Müteselsil borçlular açısından söz konusu olan genel kural burada da geçerli olacaktır. Diğer bir ifade ile alacaklının ihtarı kural olarak kendisine ihtarda bulunulan borçlu açısından hüküm ifade eder ${ }^{102}$. Ancak alacaklı ile müteselsil borçlular arasında yapılan sözleşmede alacaklının yapacağı ihtarın diğerleri için de sonuç doğuracağ 1 kararlaştırılmış ise borçlulardan birine yapılan ihtar diğer müteselsil borçluları da temerrüde düşürür. Kendisine ihtarda bulunulan müteselsil borçluya, diğer borçlular tarafından kendileri için de ihtara muhatap olma yetkisi verilmişse bu durumda da bu borçluya yapılan ihtar diğerlerini de temerrüde düşürür ${ }^{103}$.

Alacaklı ile borçlu arasında müteselsil borç ilişkisini oluşturan sözleşmede TBK m 117'de belirtilen ihtara gerek olmayan ve doktrinde dürüstlük kuralı gereği ihtar aranmayan hallerden birisi söz konusu olmadıkça alacaklının her bir müteselsil borçluya ihtarda bulunması gerekir ${ }^{104}$.

Müteselsil borçluların tümü açısından TBK m 117/f. 2 uyarınca sözleşmede bir vade kararlaştırılmış ise bu durumda söz konusu vadenin gelmesi ile bütün müteselsil borçlular ihtara gerek olmaksızın temerrüde düşer.

Her bir müteselsil borçlu için borcun muaccel olacağı zaman farklılaşabileceğinden, böyle hallerde ihtarın yapıldığ 1 tarihler de farklılık arz edebilir ${ }^{105}$. Hal böyle olunca da müteselsil borçluların temerrüt tarihleri de farklılaşmış olur.

Müteselsil borçlulardan bazıları açısından bir vade kararlaştırılmış olup, diğer bazıları açısından ise bu şekilde bir kararlaştırma bulunmayabilir. Bu durumda nezdinde bir vade kararlaştırılmış olan müteselsil borçlular ihtara gerek olmaksızın temerrüde düşecek iken, diğerleri açısından temerrüdün gerçekleşebilmesi için ihtara gerek duyulur.

Müteselsil borçlular açısından ihtar gereken hallerde müteselsil borçlulara ihtarın yapılması kural olarak şekle bağlı olmaz. Ancak müteselsil borçlulardan biri, birkaçı veya tamamı tacir olup aynı zamanda alacaklı da tacir ise, tacir olan alacaklının, tacir sıfatını haiz müteselsil borçluları temerrüde düşürebilmesi için temerrüt ihtarını, TTK m 18/f. 3’te kabul edilen yollardan biriyle yapması gerekir.

\footnotetext{
102 Canyürek (n 7) 41; Funk (n 7) 214; Tunçomağ (n 4) 1034; Feyzioğlu (n 7) 321, fn. 36; Velidedeoğlu and Özdemir (n 7) 314; Şahin Caner (n 7) 245; Tercier, Pichonnaz and Develioğlu (n 2), §33, para. 1626; Dağdelen (n 9) 105; Arat (n 7) 333; Erdoğan (n 1) 254-255; Tuhr and Escher (n 7) 307; Büren (n 7) 96; Koller (n 7), para. 75.144; Gautschi (n 8) para. 14; Krauskopf (n 7), Art. 146, para. 79; Kratz (n 9), Art. 146, para. 33.

103 Canyürek (n 7) 41; Tuhr and Escher (n 7) 307; Feyzioğlu (n 7) 321, fn. 36; Krauskopf (n 7), Art. 146, para. 79. Doktrinde Krauskopf ayrıca borçlulardan her birinin diğerinin ifa yardımcısı durumunda olması halinde, ihtarda bulunulan borçlunun diğer borçluların pasif temsilcisi olacağını ve bu halde de haklarında temerrüdün diğer koșulları da gerçekleșmiș olmak kaydıyla borçlulardan birine ihtarda bulunmakla diğer borçluların da temerrüde düşeceğini belirtmektedir. Bkz. Krauskopf (n 7), Art. 146, para. 83. Ayrica bkz. Kratz (n 9), Art. 146, para. 33.

104 Ayrica bkz. Arat (n 7) 358-359.

105 Arat (n 7) 358.
} 


\section{Borcun İfasının Mümkün Olması}

TBK'da temerrüdün gerçekleşebilmesi için borcun ifasının mümkün olması açıkça düzenlenmiş değildir. Ancak bu şartın varlığı da doktrinde haklı olarak kabul edilmektedir ${ }^{106}$. Muacceliyetten önce borcun imkânsızlaşması, bu borcun ifa edilmemesi halinin temerrüt olarak vasıflandırılmasına engel olur ${ }^{107}$. Bu halde temerrüde dair hükümler uygulama alanı bulmaz ${ }^{108}$. Böyle bir durumda imkânsızlık yüzünden borç ifa edilemediğinden, imkânsızlıkta borçlunun sorumluluk durumuna göre sonuçlar tayin edilir ${ }^{109}$. Ancak imkânsızlık temerrütten sonra meydana gelir ise bu durumda temerrüt hükümleri uygulama alanı bulur ${ }^{110}$. Ancak ifanın imkânsızlaştığı an itibariyle temerrüt de son bulur ${ }^{111}$. Bu andan itibaren ise ifa imkansızlığına ilişkin hükümler uygulama alanı bulur ${ }^{12}$.

Sözleşmenin kurulmasının ardından müteselsil borçlulardan birinin kusuru olmaksızın borcun konusunun bütün borçlular nezdinde imkânsızlaşması halinde, diğer bir deyişle kusursuz ifa imkânsızlığı halinde bütün müteselsil borçluların TBK m 136 gereğince borçtan kurtulacağ kabul edilmektedir ${ }^{113}$.

Edimin imkânsızlaşmasından müteselsil borçlulardan biri sorumlu ise bu durumda doktrinde bir görüşe göre TBK m 112 uyarınca istenebilecek tazminattan sadece edimi imkânsızlaştıran borçlu sorumlu olacağı kabul edilmektedir ${ }^{114}$. Buna göre bu durum

106 Tekinay and others (n 2) 912; Akkanat (n 81) 16; Büren (n 7) 365; Schwenzer (n 4) para. 65.02.

107 Oğuzman and Öz, Borçlar Hukuku Genel Hükümler C. 1 (n 2) para. 1526.

108 Reisoğlu (n 4) 372.

109 Oğuzman and Öz, Borçlar Hukuku Genel Hükümler C. 1 (n 2) para. 1526.

110 Tekinay and others (n 2) 912; L. M Kurt, Borçlunun Sorumlu Olmadı̆̆ Sonraki Imkânsızlık (TBK m 136) (Yetkin 2016 ) 210.

111 Reisoğlu (n 4) 372; Kurt (n 110) 210. Benzer şekilde bkz. Schwenzer (n 4) para. 65.02.

112 Kurt (n 110) 210.

113 Şahin Caner (n 7) 216; Tekinay and others (n 2) 299; Arsebük (n 13) 1019; Tekinay, Borçlular Arasında Akdi Teselsül, (Yayımlanmamış Doçentlik Tezi) (n 7) 96; Saymen and Elbir (n 10) 783; Hatemi and Gökyayla (n 1) §36, para. 34; İnan and Yücel (n 1) 549; Canbolat (n 8) 75; Kapancı (n 5) 220; Tercier, Pichonnaz and Develioğlu (n 2), §33, para. 1628; Dağdelen (n 9) 140; Olgaç (n 8) 1048; Funk (n 7) 216; Önen (n 13) 111; Keller and Schöbi Christian, Das Schweizerische Schuldrecht, B. 4, Gemeinsame Rechtsinstitute für Schuldverhältnisse aus Vertrag, unerlaubter Handlung und ungerechtfertigter Bereicherung (n 7) 14; Mazan (n 7), Art. 145, para. 7; Gauch, Schluep and Emmenegger (n 9) para. 3717 ; Gautschi (n 8) para. 43; Tuhr and Escher (n 7) 311; Berger (n 5) para. 2426; Müller (n 7), Art. 147, para. 4; Graber (n 7), Art. 144, para. 8. Ayrıca bkz. ve karş. Krauskopf (n 7), Art. 147, para. 91. Dağdelen, müteselsil borçluların aynı belirli edimi borçlanmış olmamaları halinde ise şu görüştedir: Yazara göre böyle bir durumda müteselsil borçlulardan biri için bir ifa imkânsızlığı söz konusu olduğunda, bu borçlu borçtan kurtulur, diğer borçlular hakkında da TBK m 166/f. 2 gereği durumun gereği ve borcun niteliği izin verdiği ölçüde diğer borçluların devam eden borçlarında indirime gidilmek gerekir. Borçlunun imkânsızlıkta kusuru var ise alacaklıya tazminat ödemekle yükümlü olur. Yazarın görüşü hakkında açıklamaları için bkz. Dağdelen (n 9) 138139. Bir müteselsil borçlunun şahsına ilişkin olan, onun açısından söz konusu bir ifa imkânsızlığında, sadece bu müteselsil borçlunun borçtan kurtulacağı, diğer borçluların borçlu kalmaya devam edeceği kabul edilmektedir. Bkz. Akıntürk (n 7) 176; Tekinay and others (n 2) 299; Bozer (n 7) 299. Alman hukukunda ise BGB §425'te ifa imkânsızlığına dair kusurlu olup olmama ayrımı yapılmaksızın aksi borç ilişkisinden anlaşılmadıkça ifa imkânsızlığının sadece ilgili kişisiyi etkileyeceği kabul edilmiştir. Bkz. Fikentscher and Heinemann (n 3) para. 775; Larenz (n 9) 640. Borçlunun kusuru olmaksızın meydana gelen imkansızlık ve sonuçları hakkında bilgi için bkz. Kurt (n 110) "77ff".

114 Akıntürk (n 7) 195; Feyzioğlu (n 7) 321; Arsebük (n 13) 1015; Canyürek (n 7) 39-40; Kılıçoğlu (n 9) 958; Eren (n 1) 1236; Tunçomağ (n 4) 1046-1047; Velidedeoğlu and Özdemir (n 7) 314; Saymen and Elbir (n 10) 786-787; Funk (n 7) 214; Şahin Caner (n 7) 242; Olgaç (n 8) 1047; Dalamanlı, Kazancı and Kazancı (n 8) 683; Mazan (n 7), Art. 146, para. 5; Keller and Schöbi Christian, Das Schweizerische Schuldrecht, B. 4, Gemeinsame Rechtsinstitute für Schuldverhältnisse aus Vertrag, unerlaubter Handlung und ungerechtfertigter Bereicherung (n 7) 14; Bucher (n 4) 495; Gauch, Schluep and Emmenegger (n 9), para. 3726; Gautschi (n 8) para. 43; Huguenin (n 3) para. 2305; Krauskopf (n 7), Art. 146, para. 25; Tuhr and Escher (n 7) 307; Berger (n 5) para. 2425; Graber (n 7), Art. 146, para. 5; Müller (n 7), Art. 146, para. 2; Kratz (n 9), Art. 146, para. 24; Jung (n 9), Art. 146, para. 2. 
diğer borçlular açısından TBK m 136 uyarınca bir kusursuz ifa imkânsızlığı teşkil eder ve onlar borçtan kurtulur ${ }^{115}$. Ancak bu durumun ne kadar adil olacağı tartışmaya açıktır. Zira başlangıçta borçluların tamamı tarafından edimin tamamı alacaklıya karşı taahhüt edilmiş olup, sırf bir borçlunun kusuru ile borcun imkânsızlaşmasından ötürü diğer borçluların borçtan kurtulması adil değildir. Her ne kadar borçlunun kendi davranışı ile diğer borçluların durumunu ağırlaştıramaması kuralı müteselsil borçlulukta cari ise de müteselsil borçlulardan birinin davranışı sonucunda alacaklının daha elverișsiz bir durumu kabul etmek zorunda bırakılması da kanaatimizce adil olmaz. Bu durumda menfaatler dengesine bakıldığında bir tarafta borçlunun bireysel davranışının diğer müteselsil borçluların durumunu ağırlaştıramaması kuralının sonucu ve çokluk görüşünün yansıması olarak diğer müteselsil borçluların borçtan kurtulmalarındaki (sadece imkânsızlığa kusuru ile sebep olan müteselsil borçlunun tazminat ile sorumlu olması) diğer borçluların menfaati vardır. Diğer tarafta ise başlangıçta belki de kendisine karşı müteselsil olarak borç altına gireceklerine güvenerek bu sözleşmeyi yapmaya razı olan alacaklının, müteselsil olarak borç altına girenlerden biri nezdinde gerçekleşen bir kusurlu davranış sonucunda, başlangıçta başvurabileceği birden fazla borçluyu kaybetmeme, artık sadece tek bir borçlu ile baş başa kalmama konusundaki menfaati vardır. Bu noktada kanaatimizce üstün tutulması gereken menfaat alacaklının menfaati olmalıdır.

Bu noktada bu imkânı sağlayabilecek biri mevcut, biri ise olması gereken hukuk bakımından iki çözüm akla gelebilirr'16. TBK m 165 'te müteselsil borçlulardan birinin davranışının diğerinin durumunu ağırlaştırabilmesinin sözleşmede kararlaştırılması veya kanunda bir hüküm olması halinde mümkün olduğu kabul edilmiştir. Buna göre eğer taraflar sözleşme yapılırken edimin borçlulardan birinin kusuruyla imkânsız hale gelmesi durumunda bunun sonuçlarından borçluların müteselsil olarak borçlu olacağını kararlaştırabilirler ve böyle bir kararlaştırma halinde tazminat borcu açısından müteselsil borçluluk devam eder ${ }^{117}$. Bu şekilde bir kararlaştırma olmaması durumunda ise kanunda bunu sağlayacak bir hüküm bulunmamaktadır ${ }^{118}$.

\footnotetext{
115 Bu yönde bkz. Akıntürk (n 7) 195-196; Feyzioğlu (n 7) 321; Arsebük (n 13) 1016; Kılıçoğlu (n 9) 958; Eren (n 1) 12361237; Tunçomağ (n 4) 1047; Tekinay and others (n 2) 310-311; Oser and Schönenberger (n 5) 911; Kapanc1 (n 5) 221; Şahin Caner (n 7) 243; Dağdelen (n 9) 141; Mazan (n 7), Art. 146, para. 5; Gautschi (n 8) para. 43; Huguenin (n 3) para. 2305; Becker (n 9), Art. 146, para. 2; Krauskopf (n 7), Art. 146, para. 25; Tuhr and Escher (n 7) 307; Berger (n 5) para. 2425; Müller (n 7), Art. 146, para. 2; Kratz (n 9), Art. 146, para. 24 ve para. 32; Graber (n 7), Art. 146, para. 5.

116 Doktrinde Canyürek, alacaklıdan karşı edim alacağı elde edecek olan müteselsil borçluların da imkânsızlaşan edimin değeri ile sınırlı olarak müteselsil sorumluluğunun devam etmesi gerektiğini ifade etmiștir. Zira imkânsızlıkta kusuru bulunmayan müteselsil borçluların bir taraftan kendi borçlarından kurtulmaları diğer taraftan karşı edimi talep etmeleri mümkün değildir. Yazara göre bir müteselsil borçlunun kusuru ile alacaklının durumu ağırlaștırılmamalıdır. Alacaklının zararı bu imkânsızlaşan edimin değerini aşmakta ise bu durumda aşan kısım için bizzat kusuruyla imkânsızlığa sebep olan borçlu sorumlu olur. Bkz. Canyürek (n 7) 39-40. Canyürek'in bu görüşüne mevcut düzenlemeler çerçevesinde (de lege lata) biz de iştirak etmekteyiz.

117 Bkz. Akıntürk (n 7) 195-196; Funk (n 7) 214; Arsebük (n 13) 1016; Saymen and Elbir (n 10) 787; Velidedeoğlu and Özdemir (n 7) 314; Canyürek (n 7) 38; Kılıçoğlu (n 9) 958; Şahin Caner (n 7) 243; Olgaç (n 8) 1047; Gautschi (n 8) para. 43, fn. 93; Huguenin (n 3) para. 2305; Krauskopf (n 7), Art. 146, para. 26; Tuhr and Escher (n 7) 307; Berger (n 5) para. 2425; Müller (n 7), Art. 146, para. 2.

118 Doktrinde, müteselsil borçlulardan birinin imkânsızlıktan kusurlu olarak sorumlu olması halinde bundan diğer müteselsil borçluların da sorumlu olmasını, kusurlu imkânsızlığa sebep olan müteselsil borçlunun diğerlerinin TBK m 116 anlamında
} 
Yukarıda açıklanan nedenlerle buna ilişkin düzenlemenin kanunda yer almayışı da bu açıdan bir eksikliktir. Olması gereken hukuk bakımından mütesesil borçlulardan birinin kusuru ile gerçekleşen imkânsızlıktan diğer borçluların da sorumlu olduğu kabul edilmeli ve buna ilişkin bir düzenlemeye gidilmelidir ${ }^{119}$. Buna paralel olarak alacaklıya karşı bu kusurlu ifa imkânsızlığı sonucunda TBK m 112 gereği tazminatı ödeyen müteselsil borçlunun, kusuru ile imkânsızlığa sebebiyet veren borçluya rücu imkânı da düzenlenmelidir.

Birden fazla müteselsil borçlunun da kusuru ile borcun ifasının imkânsızlaşmasına sebep olması mümkün olabilir. Kanaatimizce de lege lata bu durumda kusurlu olan müteselsil borçluların tazminat borcu bakımından müteselsil olarak sorumluluklarının devam ettiğini kabul etmek gerekir ${ }^{120}$. Bu durumda haksız fiillere ilişkin TBK m 61 hükmünün kıyasen uygulanması söz konusu olabilir. Her ne kadar kusurlu ifa imkânsızlığı sözleşmesel temelde sorumluluk olsa da TBK m 114/f. 2 hükmü gereğince haksız fiil sorumluluğuna ilişkin hükümlerin kıyasen sözleşmeye aykırılık hallerine uygulanabilir. $\mathrm{Bu}$ noktada kanaatimizce haksız fiillerdeki müteselsil sorumluluğa ilişkin TBK m 61 hükmü kıyasen kusurlu ifa imkânsızlığı hallerine uygulanabilir niteliktedir. Zira ilgili hükümde "Birden çok kişi birlikte bir zarara sebebiyet verdikleri veya aynı zarardan çeşitli sebeplerden dolayı sorumlu oldukları takdirde, haklarında müteselsil sorumluluğa ilişkin hükümler uygulanır" denilmiştir. Sözü edilen ihtimalde de birden fazla borçlu kusurlu davranışları ile borcu imkânsızlaştırmak suretiyle birlikte bir zarara sebebiyet vermektedirler. Bu nedenle bu şekilde imkânsızlığa sebebiyet veren müteselsil borçluların TBK m 112 uyarınca söz konusu olan tazminat borcu açısından da müteselsil olarak borçlu oldukları kabul edilmelidir ${ }^{121}$. Bu durumdan, imkânsızlığa sebep olmayan diğer borçluların sorumlu olup olmayacağı noktasında tek bir müteselsil borçlunun sorumlu olması hali için de lege ferenda yaptığımız açıklamalar bu ihtimal açısından da geçerlidir.

ifa yardımcısı olduğunun kabulüyle sağlanmasını savunan bir görüș de bulunmaktadır. Bu yönde olarak bkz. Arsebük (n 13) 1016. Bu görüş hakkında bilgi ve eleştirisi için bkz. Kapancı (n 5) "159ff”; Akıntürk (n 7) "196ff”. Ancak kanaatimizce Akıntürk'ün de haklı olarak belirttiği üzere (Akıntürk (n 7) 196-197) müteselsil borçlular, borçlu sıfatını haiz olduklarından, birbirlerinin ifa yardımcıları olarak nitelendirilmeleri müteselsil borçluluğun niteliğine uymaz. Ayrıca bkz. Tekinay and others (n 2) 311, fn. 32; Tekinay, Borçlular Arasında Akdi Teselsül, (Yayımlanmamış Doçentlik Tezi) (n 7) 130.

$119 \mathrm{Bu}$ noktada akla borçlu temerrüdünün sonuçları bakımından da benzer sonucun kabul edilmesinin gerekip gerekmediği gelebilir. Kanaatimizce borçlu temerrüdünün sonuçlarından diğer borçluları da doğrudan müteselsil olarak sorumlu tutulmasına yönelik bir ihtiyaç bulunmamaktadır. Zira müteselsil borçlulardan biri temerrüde düştüğünde, kusurlu ifa imkânsızlığından farklı olarak, alacaklının diğer borçlulara başvuru imkânı ortadan kalkmamaktadır. Öte yandan diğer müteselsil borçluların da borcu ifa etme imkânları da devam etmektedir. Kendi borcunu ifa ederek borçtan kurtulabilecek diğer bir müteselsil borçluyu daha ağır bir sonuçla karşı karşıya bırakmak kanaatimizce adil olmaz. Bu noktada ayrıca alacaklının menfaatinin kusurlu ifa imkânsızlığında buna sebep olan borçlunun bireysel olarak sorumlu olması halinde söz konusu olabilecek sakınca kusurlu temerrüt halinde görülmez. Bu nedenle bir borçlunun kusuru ile ifa imkânsızlığına sebep olması ve bir borçlunun kusuru ile temerrüde düşmüş olması halleri bakımından aynı sonucun kabul edilmesi gerekmez.

120 Bu yönde bkz. Akıntürk (n 7) 197; Canyürek (n 7) 38; fn. 95; Canbolat (n 8) 75; Kapancı (n 5) 220; Şahin Caner (n 7) 243; Dağdelen (n 9) 141; Keller and Schöbi Christian, Das Schweizerische Schuldrecht, B. 4, Gemeinsame Rechtsinstitute für Schuldverhältnisse aus Vertrag, unerlaubter Handlung und ungerechtfertigter Bereicherung (n 7) 15.

121 Bu yönde bkz. Dağdelen (n 9) 141-142. 


\section{E. Alacaklının İfayı Kabule Hazır Olması}

$\mathrm{Bu}$ şart TBK'da açıķa öngörülmüş değildir. Ancak doktrinde temerrüdün gerçekleşebilmesi için alacaklının ifayı kabule hazır olması gerektiği kabul edilmektedir"122. TBK m 106 gereği "Yapma veya verme edimi gereği gibi kendisine önerilen alacakl, haklı bir sebep olmaksızın onu kabulden veya borçlunun borcunu ifa edebilmesi için kendisi tarafindan yapılması gereken hazırlı fiillerini yapmaktan kaçınırsa" alacaklı temerrüdü söz konusu olur. Alacaklının temerrüdünün söz konusu olduğu sürece borçlunun temerrüdünden bahsedilemez ${ }^{123}$.

Alacaklının ifayı kabule hazır olmaması sebebiyle müteselsil borçlulardan birinin borcu ifa edememesi onun temerrüde düşmesine engel olur. Örneğin, haklı bir sebep olmaksızın müteselsil bir borçlunun ifa teklifini reddeden bir alacaklı temerrüde düşmüş olur ve bu durumda artık ifayı teklif etmiş olan müteselsil borçlu temerrüde düşmez. Acaba bu durumun diğer borçlular açısından etkisi ne olacaktır? Örneğin müteselsil borçlulardan birinin ifa teklifini reddettiği süre zarfinda, diğer müteselsil borçlular açısından kararlaştırılmış vadenin geçişi söz konusu olabilir. $\mathrm{Bu}$ durumda sözü edilen halde diğer olan müteselsil borçluların borçlu temerrüdüne düştüğünden bahsedilebilecek midir? Kanaatimizce bu soruya verilmesi gereken cevap olumsuzdur. Zira TBK m 106/f. 2'de “Alacakl, müteselsil borçlulardan birine karşı temerrüde düşerse, diğerlerine karşı da temerrüde düşmüs olur" denilmek suretiyle alacaklının temerrüdünün etkisinin diğer müteselsil borçlulara şamil olduğu kabul edilmiştir. Buna göre bir müteselsil borçlu alacaklıyı temerrüde düşürdüğünde alacaklı diğer müteselsil borçlulara karşı da temerrüde düşmüş olacaktır ${ }^{124}$. Bu durumda bir müteselsil borçlunun alacaklıyı temerrüde düşürmesi, diğer müteselsil borçlular bakımından borçlu temerrüdünün gerçekleşmesine engel olacaktır.

\section{Müteselsil Borçluların Temerrüdünün Sonuçları}

\section{A. Genel Olarak}

Borçlu temerrüdünün gerçekleşmesi ile birlikte bunun birtakım sonuçları olur. Bunlar TBK m 118'de belirtilen gecikme tazminat1, TBK m 119'da belirtilen temerrüde düssen borçlunun beklenmedik hâlden dolayı sorumluluğu, TBK m 120123 'te düzenlenen para borçlarında temerrüt faizi ve aşkın zarardan sorumluluk, karşılıklı borç doğuran sözleşmelerde TBK m 125 'te düzenlenen ifadan vazgeçerek

122 Eren (n 1) 1125; Tunçomağ (n 4) 911; Oğuzman and Öz, Borçlar Hukuku Genel Hükümler C. 1 (n 2) para. 1531; Erdoğan (n 1) 221; Akkanat (n 81) 18 .

123 Oğuzman and Öz, Borçlar Hukuku Genel Hükümler C. 1 (n 2) para. 1531; Tunçomağ (n 4) 911; Gauch, Schluep and Emmenegger (n 9) para. 2664. Ayrıca bkz. Erdoğan (n 1) 221.

124 Ayrıca bkz. Tekinay and others (n 2) 298; Tekinay, Borçlular Arasında Akdi Teselsül, (Yayımlanmamış Doçentlik Tezi) (n 7) 85; Feyzioğlu (n 7) 328; Canyürek (n 7) 100; Mazan (n 7), Art. 148, para. 9; Koller (n 7), para. 75.150; Gautschi (n 8) para. 46; Krauskopf (n 7), Art. 146, para. 155; Müller (n 7), Art. 147, para. 6; Schwenzer (n 4) para. 88.25; Jung (n 9), Art. 147, para. 2. Bu husus Alman hukukunda BGB $\$ 424$ 'te açıkça düzenlenmiştir. Ayrıca bkz. Fikentscher and Heinemann (n 3) para. 775; Brox and Walker Wolf-Dietrich (n 8), §37, para. 13; Larenz (n 9) 638; Medicus and Lorenz (n 14) para. 895. 
olumlu zararın talebi ile sözleşmeden dönerek olumsuz zararın tazmininin talep edilmesi imkânı ve sürekli edimli sözleşmelerde sözleşmenin feshi ile olumlu zararın tazmininin talep edilmesidir. Aşağıda bu sonuçlar müteselsil borçluluk bakımından incelenecektir.

\section{B. Borçlu Temerrüdünün Genel Sonuçları Bakımından}

\section{Aynen İfa ve Gecikme Tazminatı Talebi}

Borçlu temerrüdünün şartlarının gerçekleşmesi borcun sona ermesine neden olmadığından alacaklı borçludan ifa talebinde bulunabilir ve buna karşıılık borçlu da gecikmiş de olsa edimi ifa edebilir ${ }^{125}$. İmkânsızlık söz konusu olmadığı sürece borcun aynen ifası mümkündür ${ }^{126}$. Buna göre temerrüde düşmüş olan her bir müteselsil borçlunun edimi ifa etmesi mümkündür. Alacaklının da her bir müteselsil borçludan ifayı talep etme imkânı devam eder. Diğer bir deyişle, borçlunun temerrüde düşmesi, borçlunun aynen ifa yükümlülüğünü sona erdirmediği gibi, alacaklıya da ifanın yerine tazminat talep etme hakkin 1 vermez ${ }^{127}$.

Borçlunun borcunu gecikmiş olarak ifa etmesi alacaklının zarara uğramasına sebebiyet verebilir. Böyle hallerde TBK m 118 alacakliya gecikme tazminatı isteme imkânı tanımaktadır. Bu hükme göre, "Temerrüde düşen borçlu, temerrüde düşmekte kusuru olmadığını ispat etmedikçe, borcun geç ifasından dolayl, alacaklının uğradı̆̆ zararl gidermekle yükümlüdür".

Gecikme tazminatı, ifadaki gecikme nedeniyle alacaklının uğradığı zararın giderilmesi için ödenecek tazminatı ifade eder ${ }^{128}$. Bu tazminat alacaklının gecikme olmaksızın borcun ifasındaki menfaatine yönelir ${ }^{129}$. Gecikme tazminatının kapsadığ1 zararlar temerrüdün gerçekleştiği tarihten ifanın gerçekleştiği tarihe kadar geçen dönemdeki zararlardır ${ }^{130}$. Gecikme tazminatı borçlunun temerrüdünün bir sonucudur ${ }^{131}$. Bu nedenle muacceliyetten sonra ancak temerrütten önce gerçekleşen bir ifa TBK m 118 bakımından bir geç ifa teşkil etmeyeceğinden bir zarardan da bahsedilemez ${ }^{132}$. Böyle hallerde bir gecikme tazminatının istenmesi mümkün olmaz.

\footnotetext{
25 Eren (n 1) 1126. Benzer şekilde bkz. Gauch, Schluep and Emmenegger (n 9) para. 2667.

126 Eren (n 1) 1127.

127 Tekinay and others (n 2) 920.

128 Eren (n 1) 1130.

129 Oğuzman and Öz, Borçlar Hukuku Genel Hükümler C. 1 (n 2) para. 1582.

130 Kılıçoğlu (n 9) 893.

131 Oğuzman and Öz, Borçlar Hukuku Genel Hükümler C. 1 (n 2) para. 1585.

132 Eren (n 1) 1130.
} 
TBK m 118 uyarınca istenebilecek zarar olumlu zarardır ${ }^{133}$. Bunun yanında gecikme tazminatından sorumluluk için borçlunun kusurlu olması şarttır ${ }^{134}$. Borçlu ancak temerrüde düşme olgusunda kendi kusurunun olmadığını ispat etmesi halinde zararı tazmin borcundan kurtulabiliri ${ }^{135}$. Diğer bir ifade ile borçlu karine olarak kusurlu kabul edilir ${ }^{136}$.

Müteselsil borçluluğun bulunduğu bir sözleşme ilişkisinde de alacaklı kural olarak temerrüde düşmekte kusuru bulunan müteselsil borçludan gecikme tazminatı talep edebilecektir ${ }^{137}$. Alacaklının diğer müteselsil borçlulara başvurması kural olarak mümkün olmaz. Birden fazla müteselsil borçlunun temerrüde düştüğü bir durumda temerrüde düşmekte kusuru olmayan müteselsil borçludan gecikme tazminatı talep edilmesi mümkün değildir.

$\mathrm{Bu}$ noktada alacaklı karşısındaki müteselsil borçlulardan iki veya daha fazlasının kusuru ile temerrüde düşmesi halinde, alacaklının uğradığı zarar nedeniyle isteyebileceği gecikme tazminatından kusurlu olarak temerrüde düşen bu borçlular arasında teselsülün devam edip etmeyeceği akla gelmektedir. Kanaatimizce bu soruya olumlu cevap verilmelidir. Zira söz konusu durumda alacaklının uğradığ zararı toplamda tek bir meblağdan müteşekkildir. Kanaatimizin temellendirmek için akla gelebilecek diğer ihtimalleri ele almak isabetli olacaktır.

İlk durumda gecikme tazminatını oluşturan meblağın temerrüde düşen her bir borçludan ayrı ayrı talep edilebileceği düşünülebilir. Ancak bu, alacaklının uğradığı zarardan fazla miktarda tazminat elde etmesi anlamına gelecektir ki bu durum tazminat hukukunun temel prensibi olan alacaklıyı zenginleştirmeme prensibine aykırı olur. $\mathrm{Bu}$ durumu bir örnek ile somutlaştırmak gerekirse, müteselsil borçlulardan üçü kusurları ile temerrüde düşmüş ve alacaklının da bu nedenle 30.000 TL tutarında bir zararı olduğunu varsayalım. Bu halde alacaklının müteselsil borçluların her birinde ayrı ayrı 30.000 TL talep edebileceği kabul edilirse toplamda 90.000 TL elde ederek zararının çok ötesinde bir menfaat elde etmiş olur.

\footnotetext{
133 Oğuzman and Öz, Borçlar Hukuku Genel Hükümler C. 1 (n 2) para. 1583; Eren (n 1) 1131; Erdoğan (n 1) 222; İnan and Yücel (n 1) 621; Bucher (n 4) 360. Bu zararın kapsamına nelerin girebileceği hususunda bkz. Kılıçoğlu (n 9) 893; Tunçomağ (n 4) 923; Göktürk (n 7) 262; Oğuzman and Öz, Borçlar Hukuku Genel Hükümler C. 1 (n 2) para. 1583; Tekinay and others (n 2) 925; Funk (n 7) 164; Feyzioğlu (n 7) 243; Reisoğlu (n 4) 373-374; Gauch, Schluep and Emmenegger (n 9) para. 2673; Bucher (n 4) 360, fn. 125; Tuhr and Escher (n 7) 144-145; Furrer and Müller-Chen (n 14) 602-603.

134 Eren (n 1) 1132; Kılıçoğlu (n 9) 893; Erdoğan (n 1) 222; Gauch, Schluep and Emmenegger (n 9) para. 2671; Keller and Schöbi Christian, Keller, Max/Schöbi, Christian, Das Schweizerische Schuldrecht, B. 1, Allgemeine Lehren des Vertragrechts (n 68) 268.

135 Tekinay and others (n 2) 926; Oğuzman and Öz, Borçlar Hukuku Genel Hükümler C. 1 (n 2) para. 1587; Feyzioğlu (n 7) 243; Saymen and Elbir (n 10) 741; Tuhr and Escher (n 7) 143; Furrer and Müller-Chen (n 14) 603; Keller and Schöbi Christian, Keller, Max/Schöbi, Christian, Das Schweizerische Schuldrecht, B. 1, Allgemeine Lehren des Vertragrechts (n 68) 268. Ayrica bkz. Funk (n 7) 164.

136 Oğuzman and Öz, Borçlar Hukuku Genel Hükümler C. 1 (n 2) para. 1587; Reisoğlu (n 4) 374.

137 Bu yönde bkz. Arsebük (n 13) 1015; Edgü (n 8) 109.
} 
İkinci olarak gecikme tazminatını oluşturan meblağdan, kusurları ile temerrüde düşmüş olan borçluların kısmi borçluluk esasına göre sorumlu tutulmaları akla gelebilir. Ancak bu durumun sakıncası da temerrüde düşen kusurlu borçlulara, kendilerine düşene düşenin dışında kalan kısmı reddetme imkânı sağlamasıdır. Bu durumun ise temerrüde düşen borçlular karşısındaki alacaklının menfaatini aşırı ölçüde zedeleyeceği aşikardır. Bir önceki paragraftaki örnek üzerinden somutlaştırmak gerekirse, bu halde 30.000 TL tutarındaki gecikme tazminatından her bir borçlunun 10.000 TL'lik kısmı ile sorumlu olduğunun kabulü gerekir. Böyle bir durumda her bir borçludan alacaklının 30.000 TL'nin tamamını talep etme imkânı olmaz. Bu şekilde bir talebin varlığı halinde temerrüde düşen müteselsil borçlular bu talebi reddetme olană̆ına kavuşur.

Kabul ettiğimiz görüş uyarınca kusurlu olarak temerrüde düşen müteselsil borçluların gecikme tazminatı bakımından da müteselsil olarak sorumlu olduğu kabul edilir ise hem alacaklı gecikme tazminatı oluşturan meblağı bir kez elde etmekle söz konusu borç sona ereceğinden alacaklı aşırı bir menfaat elde etmez, hem de alacaklı söz konusu bedelin tamamı için her bir temerrüde düşen borçluya başvurabileceğinden (borçlular alacaklının ifa talebini reddedemeyeceğinden) alacaklı yeterince korunmuş olur. Yine verilen örnek üzerinden gitmek gerekirse 30.000 TL tutarındaki gecikme tazminatı için kusurlu olarak temerrüde düşen üç borçluya da başvurulabilir ve her birinden ancak toplamda 30.000 TL talep edilebilir ve bu tutar alacaklıya ödendiği takdirde borç sona erer.

Müteselsil borçluluğun söz konusu olduğu bir sözleşmede alacaklı borçlular için farklı vadeler kararlaştırabilir. Bunun sonucu olarak da müteselsil borçlulardan bazıları temerrüde düşmüş iken diğerleri için henüz temerrüt gerçekleşmemiş olabilir. Temerrüde düşmemiş olan borçlular açısından sözleşmede kararlaştırılan edimi ifa etmek suretiyle borcu sona erdirme imkânı mevcuttur. Böyle bir durumda, alacaklının, temerrüde düşen borçludan gecikme tazminatını talep etme imkânının devam edip etmediği sorusu ortaya çıkmaktadır. Kanaatimizce bu durumda alacaklı temerrüde düşmüş olan kusurlu müteselsil borçludan, asıl borç sona ermiş olsa dahi gecikme tazminatını talep edebilir ${ }^{138}$.

Bir diğer husus, birden fazla müteselsil borçlunun kusurları ile temerrüde düşmelerine karşın temerrüdün gerçekleşme tarihlerinin birbirinden farklı olması halinde gecikme tazminatlarından sorumluluklarının ne şekilde olması gerektiği

\footnotetext{
38 Alacaklı borcu ifa eden borçlunun ifa zamanını sözleşme kurulduktan sonra ertelemiş ise (bir tecil anlaşması yapılmış ise) acaba bu durum alacaklının gecikme tazminatı ödeyen borçlunun durumunu ağırlaştırması olarak kabul edilebilecek midir? $\mathrm{Bu}$ halde temerrüde düşmüş olan müteselsil borçlu gecikme tazminatından tek başına sorumlu olacak ve diğer müteselsil borçlulara rücu imkânı da bulunmayacaktır. Bunun bir an için tecil anlaşmasının temerrüde düşen borçlunun durumunu diğer tecil anlaşması yapılan borçlu lehine ağırlaştırdığı ve bu nedenle TBK m 168/f. 2 uyarınca alacaklının bunun sonuçlarına katlanması gerektiği düşünülebilirse de gecikme tazminatının talep edilmesi için kusur arandığından ve borcu ifa eden borçlunun ifa zamanı ertelenmese idi kusurlu olarak temerrüde düşeceğini varsaymak mümkün olmadığından söz konusu hükümden kusurlu olarak temerrüde düşen borçlunun yararlanması mümkün olmamalı ve alacaklının sorumluluğuna gidememelidir.
} 
hususudur. Gerçekten müteselsil borçlulardan biri daha erken bir zamanda temerrüde düşebilecek iken, bir diğeri daha geç bir zamanda temerrüde düşebilir. Bu süreçte de alacaklının gecikmeden kaynaklanan zararı zamanla artabilir. Böyle durumlarda kanaatimizce sonradan temerrüde düşen müteselsil borçlunun zarardan sorumluluğu kadar gecikme tazminatından da müteselsil sorumluluğunun mevcudiyeti kabul edilmelidir. Örneğin müteselsil borçlulardan ilkinin temerrüde düşmesinden, müteselsil borçlulardan ikincisinin temerrüde düşüş anına kadar 5.000 TL'lik bir gecikme zararı meydana gelmiş; ikincisinin temerrüde düştüğü andan itibaren de 10.000 TL'lik bir gecikme zararı meydana gelmiş olabilir. Bu durumda kusurlu olarak temerrüde düşen iki müteselsil borçlu da gecikme tazminatının 10.000 TL'lik k1smından müteselsil olarak sorumlu olacak, 5.000 TL'lik gecikme tazminatından ise ilk olarak temerrüde düşen borçlu tek başına sorumlu olacaktır.

\section{Beklenmedik Hâlden Sorumluluk}

TBK m 119'da temerrüde düşen borçlunun beklenmedik halden sorumlu olduğu ifade edilmiştir. Maddenin ikinci fikrasında ise borçlunun beklenmedik halden sorumlu olmaktan kurtulması için temerrüde düşmekte kusurlu olmadiğını veya borcunu zamanında ifa etse dahi beklenmedik halin ifa konusu şeye zarar vereceğini ispatlaması gerektiği düzenlenmiştir.

$\mathrm{Bu}$ sorumluluk temerrüt devam ederken beklenmedik bir hal nedeniyle edimin konusunun yok olması veya kötüleşmesi halinde söz konusu olmaktadır ${ }^{139}$. Bu halde borçlunun edimin kusursuz imkânsızlığından ve borca aykırı davranışın beklenmedik sonuçlarından sorumluluğu söz konusu olmaktadır ${ }^{140}$.

Borçlu sorumluluktan kurtulmak istiyor ise bu durumda ispatlaması gereken olgulardan biri, temerrüde düşmede kusurunun bulunmadığıdır ${ }^{141}$. Bir diğeri ise borç temerrüt gerçekleşmeksizin ifa edilse idi dahi beklenmedik halden doğan kazanın alacaklı zararına ifa konusuna isabet edeceğinin ispatıdır ${ }^{142}$.

\footnotetext{
139 Eren (n 1) 1133; Keller and Schöbi Christian, Keller, Max/Schöbi, Christian, Das Schweizerische Schuldrecht, B. 1, Allgemeine Lehren des Vertragrechts (n 68) 269. Benzer yönde bkz. Tercier, Pichonnaz and Develioğlu (n 2), §25, para. 1292; Gauch, Schluep and Emmenegger (n 9) para. 2681; Tuhr and Escher (n 7) 145.

140 Oğuzman and Öz, Borçlar Hukuku Genel Hükümler C. 1 (n 2) para. 1590,

141 Eren (n 1) 1133; Tunçomağ (n 4) 928; İnan and Yücel (n 1) 621; Tercier, Pichonnaz and Develioğlu (n 2), §25, para.1293; Tekinay and others (n 2) 927; Erdoğan (n 1) 223; Edgü (n 8) 142; Feyzioğlu (n 7) 244; Gauch, Schluep and Emmenegger (n 9) para. 2683; Furrer and Müller-Chen (n 14) 603; Kramer and Probst (n 3) para. 492. Doktrinde Kılıçoğlu temerrüde düşmede kusursuz olduğunun ispatlanmasının gerekmediğini; TBK m 119'da yer alan temerrüde düşmede kusurun olmadığının ispatı ile sorumluluktan kurtulmanın zarar ile ilgili olduğunu, beklenmedik halden sorumluluktan kurtulma ile ilgili olan hususun ise zamanında ifa halinde dahi beklenmedik halin ifa konusuna zarar vereceğinin ispat edilmesi olduğunu ifade etmiştir. Bkz. Kılıçoğlu (n 9) 895.

142 Eren (n 1) 1133; Tunçomağ (n 4) 929; Saymen and Elbir (n 10) 742; Oğuzman and Öz, Borçlar Hukuku Genel Hükümler C. $I$ (n 2) para. 1593; Tekinay and others (n 2) 927; Hatemi and Gökyayla (n 1), §26, para. 80; Kılıçoğlu (n 9) 895; İnan and Yücel (n 1) 621; Tercier, Pichonnaz and Develioğlu (n 2), §25, para. 1293; Edgü (n 8) 142; Funk (n 7) 164; Feyzioğlu (n 7) 245; Büren (n 7) 370; Gauch, Schluep and Emmenegger (n 9) para. 2684; Furrer and Müller-Chen (n 14) 603; Kramer and Probst (n 3) para. 492.
} 
Müteselsil borçlulardan biri temerrüde düşmüş iken beklenmeyen hal gerçekleşmiş ise bu durumda beklenmeyen halden temerrüde düşmüş olan bu borçlu sorumlu olur $^{143}$.

Bütün müteselsil borçluların temerrüde düşmesinin ardından beklenmedik hal gerçekleşir ise bundan bütün müteselsil borçlular kural olarak sorumlu olur. $\mathrm{Bu}$ sorumluluğun da temerrüde düşmüş olan borçlular açısından müteselsil sorumluluk olmas1 gerekir.

$\mathrm{Bu}$ noktada birden fazla müteselsil borçlunun temerrütte olması haline ilişkin durumlarda sorumluluktan kurtulmaya ilişkin bu son imkândan ne şekilde yararlanılabileceği ele alınabilir. Temerrüde düşme zamanları aynı olmak kaydıyla ${ }^{144}$ temerrüde düşmüş olan birden fazla müteselsil borçlu bulunmakta ise ve bunların borçlanmış oldukları edim aynı ise -örneğin her bir müteselsil borçlu dükkanlarında bulunan buğdaylardan on çuval buğday teslim etmeyi borçlanmış olsun- bu durumda kendisinden beklenmeyen hal nedeniyle tazminat istenen borçlunun ifa zamanında gerçekleşse idi dahi zararın gerçekleşeceğini ispat etmesi halinde, temerrütte olan diğer müteselsil borçlunun da sorumluluktan kurtulduğu kabul edilmelidir. Zira söz konusu durumda hangi müteselsil borçlu borcu zamanında ifa ederse etsin o zararın alacaklının nezdinde gerçekleşeceği açıktır. Buna karşın yine temerrüde düşme zamanları aynı olmak kaydıyla, bu kez borçluların farklı edimleri müteselsil olarak borçlanmaları halinde ise, her durumda bu sonuç kabul edilemez. $\mathrm{Bu}$ nedenle bu hallerde her bir durumun özellikleri göz önünde bulundurularak ayrı ayrı değerlendirme yapılmalıdır. Böyle bir halde müteselsil borçluların edimlerinin birbirinden farklı olması halinde bazı durumlarda borcun zamanında ifa edilmesi durumunda zararın yine de gerçekleşeceği savunması, diğer borçluya etki edebileceği gibi etmeyebilir de. Örneğin, iki kişiden biri bir yarış atını diğeri de bir otomobili müteselsil olarak borçlanmışlar ve aynı zamanda temerrüde düşmüşler ve otomobil ve yarış atı beklenmedik hal sebebiyle (örneğin yangın) telef olmuş ise, otomobilin teslimini borçlanmış olan müteselsil borçlunun yukarıda zikredilen savunmada bulunması kural olarak diğer müteselsil borçluyu da tazmin borcundan kurtarmaz. Zira alacaklı açısından bir otomobilin muhafazası için gereken yer ve bir yarış atının muhafazası için gereken yer aynı değildir.

143 Dağdelen (n 9) 106; Tunçomağ (n 4) 1046; Feyzioğlu (n 7) 321; Arsebük (n 13) 1015; Eren (n 1) 1236; Tuhr and Escher (n 7) 307; Krauskopf (n 7), Art. 146, para. 18; Berger (n 5) para. 2424.

144 Zira borçluların temerrüde düşme tarihlerinin farklı olması halinde; müteselsil borçlulardan biri için ifa temerrüde düşmeksizin yapılmış olması halinde zarar meydana gelmeyebilecek iken, diğer müteselsil borçlu açısından aynı durum söz konusu olmayabilir. Örneğin, müteselsil borçluların on gün arayla temerrüde düşmüş olduğu varsayılır ve aradaki beşinci gün zararı meydana getiren olay (örneğin sel) meydana gelir ise, temerrüde on gün önce düşen borçlunun borcunu zamanında ifa etseydi dahi söz konusu zararın şeye isabet edeceğini ispat edebileceğini söylemek mümkün iken, o tarihte henüz temerrüde düşmemiş olan müteselsil borçlunun bu şekilde bir savunma yapması mümkün olmaz. 


\section{Borçlu Temerrüdünün Para Borçları Açısından Sonuçları Bakımından}

\section{Temerrüt Faizi}

Temerrüt faizi, borçlunun para borcunu ödemede temerrüde düşmesi halinde, kural olarak temerrüt anından başlamak üzere ve temerrüdün devamı boyunca ödeme yükümlülüğü altında bulunduğu faiz olarak ifade edilebilir ${ }^{145}$. Borçlu para borcunu ödemede temerrüde düsserse, TBK m 120 ve 3095 sayılı Kanuni Faiz ve Temerrüt Faizine İlişkin Kanun ${ }^{146}$ gereğince temerrüt faizi ödeme zorunluluğu vardır ${ }^{147}$. Bu faiz kural olarak temerrüdün gerçekleştiği günü izleyen günden itibaren işlemeye başlar. ${ }^{148}$. İşleyen bu faiz ise borcun ifa edildiği gün son bulur ${ }^{149}$. Borçlunun temerrüt faizi ödeme yükümlülüğünün söz konusu olması için tarafların anlaşmasına gerek yoktur zira bu yükümlülüğün kaynağ 1 kanundur ${ }^{150}$. Temerrüt faizinin ödenmesi için borçlunun kusurunun veya zararının varlığı aranmaz ${ }^{151}$. Asıl borcun miktarı, temerrüdün ne kadar devam ettiği ve faiz oranı, temerrüt faizine ilişkin olarak alacaklının faize ilişkin hakkının kapsamını belirler ${ }^{152}$.

Temerrüt faizi oranı sözleşme ile kararlaştırılabilir. Taraflar arasında bir temerrüt faizi oranı kararlaştırılmamış ise bu durumda temerrüt faizi oranı 3095 sayılı Kanun uyarınca tespit edilir.

Müteselsil borçlular açısından temerrüt faizinin arz ettiği özellikler ele alındığında ilk olarak alacaklının her bir borçlu ile ayrı bir faiz oranı kararlaştırabileceği zikredilebilir. Alacaklı her bir müteselsil borçlu ile ayrı ayrı ve farklı oranlarda temerrüt faizi kararlaştırabilir. Sözleşmeye konu olan işin ticari bir iş olup olmadığına göre yapılacak temerrüt faizi anlaşmasına TBK m 120/f. 2'deki sınırların uygulanıp uygulanmayacağı belirlenmelidir.

Alacaklı müteselsil borçluların bir kısmı ile temerrüt faiz oranını kararlaştırmış, diğer kısmı ile kararlaştırmamış da olabilir. Bu halde kararlaştırılanlar hakkında kararlaştırılan oran, diğerleri hakkında da kanuni faiz oranı uygulanır.

\footnotetext{
45 Nami Barlas, Para Borçlarının Ifasında Borçlunun Temerrüdü ve Bu Temerrüt Açısından Düzenlenen Genel Sonuçlar (Kazanc1 1992) 126.

146 R.G., T. 19.12.1984, S. 18610.

147 Eren (n 1) 1127.

148 Reisoğlu (n 4) 376; Barlas (n 145) 171.

149 Reisoğlu (n 4) 376.

150 Eren (n 1) 1127

151 Oğuzman and Öz, Borçlar Hukuku Genel Hükümler C. 1 (n 2) para. 1600; Tunçomağ (n 4) 920-921; Tekinay and others (n 2) 930; Eren (n 1) 1128; Saymen and Elbir (n 10) 742-743; İnan and Yücel (n 1) 622; Tercier, Pichonnaz and Develioğlu (n 2), §25, para. 1295; Erdoğan (n 1) 224; Funk (n 7) 165; Feyzioğlu (n 7) 247; Barlas (n 145) 133-134; Tuhr and Escher (n 7) 146; Bucher (n 4) 362; Schwenzer (n 4) para. 66.08; Keller and Schöbi Christian, Keller, Max/Schöbi, Christian, Das Schweizerische Schuldrecht, B. 1, Allgemeine Lehren des Vertragrechts (n 68) 267.

152 Barlas (n 145) 169.
} 
Para borcunu ödemeyen müteselsil borçlulardan sadece temerrüde düşenden temerrüt faizi talep edilebilir ${ }^{153}$. Temerrüde düşmeyenlerden faiz talep edilebilmesi mümkün değildir. Ancak birden fazla müteselsil borçlu temerrüde düşmüş ve faiz ödeme borcu altında ise bu halde kanaatimizce söz konusu olacak temerrüt faizinden de müteselsilen sorumlu olmaları gerektiği kabul edilmelidir. Ancak temerrüt faizinin miktarı zamanla arttığından, müteselsil borçluların temerrüt faizi bakımından da ne kadarlık bir miktarda müteselsil olarak sorumlu olduklarının tespiti önem arz eder. Zira müteselsil borçluların temerrüde düştükleri tarih aynı olabileceği gibi, birbirinden farkl1l1k da arz edebilir. Bu da ödenmesi gereken temerrüt faizinin miktarını farklılaştıracaktır. Bunun yanı sıra kararlaştırılan temerrüt faizi oranı da farklılık arz edebileceğinden bu da dikkate alınmalıdır.

Müteselsil borçlular para borcunu ödemekte temerrüde aynı tarihte düşmüşler ve sözleşmede kararlaştırılan temerrüt faizi oranı bütün müteselsil borçlular için aynı ise veya sözleşmede müteselsil borçlular bakımından bir temerrüt faizi oranı kararlaştırılmadığından bütün borçlular açısından kanuni temerrüt faizi oranı uygulanacak ise, bütün borçlular için temerrüt faizinin miktarı aynı olacağından, bütün temerrüt faizi tutarından müteselsilen sorumlu olacaklardır.

Müteselsil borçlular para borcunu ödemekte temerrüde aynı tarihte düşmüşler ve sözleşmede müteselsil borçlular için farklı temerrüt faizi oranı kararlaştırılmış ise veya bazıları ile kararlaştırılmadığı için kanuni temerrüt faizi oranı uygulanacak ise, bu durumda kanaatimizce temerrüt faizinin miktarı bakımından her bir müteselsil borçlunun işlemiş temerrüt faizi miktarı az olan kısımlar bakımından müteselsil olarak, bunu aşan kısımlar için ise tek başına sorumlu olduğu kabul edilmelidir. Örneğin müteselsil borçlulardan B için işlemiş olan temerrüt faizi miktarı $1.000 \mathrm{TL}$ ve $\mathrm{C}$ için işlemiş olan temerrüt faizi miktarı $3.000 \mathrm{TL}$ ise ve $\mathrm{C}$ için işlemiş olan temerrüt faizi miktarı $8.000 \mathrm{TL}$ olduğunu kabul edelim. Bu durumda işlemiş olan temerrüt faizinin 1.000 TL'lik kısmından B, C ve D müteselsilen, 3.000 TL'lik kısımdan C ve D müteselsilen ve geri kalan 5.000 TL'lik kısımdan ise D tek başına sorumlu olur.

Aynı çözüm müteselsil borçluların temerrüde düştükleri tarihin farklı olması halinde de kabul edilebilir. İlk olarak müteselsil borçluların temerrüde düştükleri tarihin farklı ve temerrüt faizi oranlarının aynı olması hali ele alınabilir. Bu durumda örneğin kararlarştırılmış temerrüt faizi oranları aynı olan B temerrüde erken erken düştüğü için $8000 \mathrm{TL}, \mathrm{C}$ temerrüde $\mathrm{B}$ 'den sonra düştüğü için $3.000 \mathrm{TL}$ ve $\mathrm{D}$ ise temerrüde en son düştüğ̈ için $1.000 \mathrm{TL}$ temerrüt faizi tutarını ödeme borcu altında ise; 1.000 TL'nin ödenmesinden B, C ve D müteselsilen, 3.000 TL' nin ödenmesinden $\mathrm{B}$ ve $\mathrm{C}$ müteselsilen ve geri kalan 5.000 TL'nin ödenmesinden ise D tek başına

53 Feyzioğlu (n 7) 321; Tekinay, Borçlular Arasında Akdi Teselsül, (Yayımlanmamış Doçentlik Tezi) (n 7) 128-129; Oser and Schönenberger (n 5) 911; Arsebük (n 13) 1015; Eren (n 1) 1236; Dağdelen (n 9) 106; Tuhr and Escher (n 7) 307; Krauskopf (n 7), Art. 146, para. 17. 
sorumlu olur. İkinci olarak müteselsil borçluların hem temerrüde düşme tarihleri hem de temerrüt faizi oranlarının birbirinden farklı olması hali değerlendirilmelidir. Buna göre örneğin sırasıyla ilk olarak $\mathrm{C}$ daha sonra $\mathrm{B}$ ve en son da $\mathrm{D}$ temerrüde düşmüş ve $\mathrm{D}$ için söz konusu olan temerrüt faizi oranı diğerlerine nazaran daha yüksek olduğundan $8.000 \mathrm{TL}, \mathrm{B}$ için $3.000 \mathrm{TL}$ ve $\mathrm{C}$ için de $1000 \mathrm{TL}$ temerrüt faizi işlemiş olabilir. Bu durumda 1.000 TL'nin ödenmesinden B, C ve D müteselsilen, 3.000 TL'nin ödenmesinden 3.000 TL'nin ödenmesinden B ve D müteselsilen ve geri kalan 5.000 TL'nin ödenmesinden ise D tek başına sorumlu olur.

Temerrüde düşme tarihleri birbirinden farklı olan müteselsil borçlular açısından farklı temerrüt faizi oranları söz konusu ise bu durumda ödeme tarihinde işlemiş faiz tutarı az olan oranında müteselsil sorumluluğun var olduğu kabul edilmelidir. $\mathrm{Bu}$ ihtimalde temerrüde düşmekte öncelik sonralık ilişkisinin esas alınması yanıltıcı olabilir. Zira müteselsil olarak borç altına giren borçlulardan sonradan temerrüde düşen borçlu için söz konusu olan faiz oranı önceden temerrüde düşmüş olanın faiz oranından daha fazla olabilir ve bu da temerrütte bulunulan süre boyunca artarak daha önceki bir tarihte temerrüde düşmüş olan müteselsil borçlunun ödemesi gereken temerrüt faizi tutarını aşabilir. Bu nedenle bu ihtimalde somut olayda temerrüt faizi tutarları hesaplanarak müteselsil borçluların işlemiş faiz tutarlarının en azı oranında müteselsil sorumluluğun bulunduğunu kabul etmek isabetli olur.

Temerrüt faizi alacağı, feri bir alacak olduğu için alacaklının çekince ileri sürmeksizin ifayı kabul etmesi halinde TBK m 131/f. 2 uyarınca asıl alacak ile beraber son bulur ${ }^{154}$. Buna göre temerrüde düşmüş borçlulardan biri asıl borcu ifa etmiş ise alacaklı bu ifayı kabul ederken çekince ileri sürmez ise temerrüt faizi isteme hakkını da kaybeder. Bu noktada akla, bir müteselsil borçlunun temerrüde düşmesine karşın, asıl borcu temerrüde düşmeyen borçlunun ifa etmesi halinde, alacaklının temerrüde düşen müteselsil borçludan temerrüt faizi talep edip edemeyeceği, bunun mümkün olduğu kabul edilir ise temerrüde düşmemiş olan borçlunun ödemesini kabul ederken, alacaklının temerrüde düşen müteselsil borçlu bakımından işlemiş temerrüt faizini talep edebilmesi için bir çekince ileri sürmesinin gerekip gerekmediği gelmektedir.

Kanaatimizce ilk soruya verilmesi gereken cevap olumludur. Müteselsil borçlulukta müteselsil borçluların borçları birbirinden nispi olarak bağımsızlık arz eder. $\mathrm{Bu}$ nedenle temerrüde düşmeyen alacaklının asıl borcu sona erdirmiş olması, temerrüt nedeniyle temerrüt faizi işlemiş olan müteselsil borçlunun bu borcunu ortadan kaldırmaz. İkinci soruya verilmesi gereken cevap ise kanaatimizce olumsuzdur. Zira alacaklının çekinceyi borcu ödemiş olan -ve temerrüde düşmediği için faizi ödemekle de yükümlü olmayan- bir müteselsil borçluya ileri sürmesinin bir anlamı ancak müteselsil borçluların birbirlerini temsil yetkisini haiz olması durumunda bir anlam

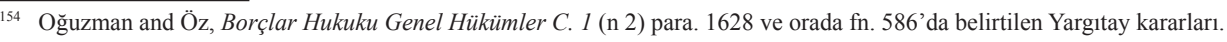


taşıyabilir. Bunun dişında kanaatimizce TBK m 131/f. 2 hükmünün amacı da bunu desteklemez. Söz konusu hüküm kanaatimizce asıl borcu ifa etmekle yükümlü olan kişi ile işlemiş faiz veya cezai şartı yerine getirmekle yükümlü olan kişilerin aynı olmaları halinde uygulama alanı bulmalıdır. Bu nedenlerle alacaklı faiz ödeme borcu altında olmayan bir müteselsil borçlunun ifasını kabul ederken çekince ileri sürmüş olmasa dahi temerrüt faizini temerrüde düşmüş olan müteselsil borçludan talep edebilir.

\section{Așkın Zarar}

Temerrüt faizinin üzerinde gerçekleşen ve alacaklının iradesi olmaksızın onun malvarlığında meydana gelmiş olan zarar, aşkın zarar olarak ifade edilir ${ }^{155}$.

Para borçlarında borçlunun temerrüde düşmesiyle işleyecek temerrüt faizi ile karşılanmayan bir zararı bulunabilir. TBK m 122/f. 1 bu durumlar için aşkın zararın da alacaklı tarafından talep edilebileceğini düzenlemiştir. Bu hükme göre, "Alacakl, temerrüt faizini aşan bir zarara uğramış olursa, borçlu kendisinin hiçbir kusuru bulunmadığını ispat etmedikçe, bu zararı da gidermekle yükümlüdür’.

$\mathrm{Bu}$ maddeden çıkan ve aşkın zararın talep edilebilmesi için gereken şartlar, alacaklının temerrüt faizini aşan bir zararının varlığ $1^{156}$ ve borçlunun kusurlu olmasıdır ${ }^{157}$. Ancak bu madde anlamında aşkın zarardan sorumluluk için borçlu karine olarak kusurlu sayılmıştır. Aşkın zararı tazmin etmekten kurtulmak isteyen mütemerrit borçlunun, temerrüde düşmekte kusurunun bulunmadığını ispat etmesi gerekir.

Bir para borcunun ifası için müteselsil olarak borç altına girenlerden, kusuru ile temerrüde düşmüş olanlar, alacaklının temerrüt faizi ile karşılanmayan bir zararları mevcut ise bu aşkın zararı da karşılamak durumundadır. Kanaatimizce kusuru ile temerrüde düşen müteselsil borçlular, aşkın zararın karşılanmasından da müteselsilen sorumlu olmalıdırlar. Temerrüde kusuru ile düşmemiş olan müteselsil bir borçlunun ise bu şekilde bir sorumluluğu yoktur.

Aşkın zararın giderilmesi noktasında müteselsil olarak sorumlu kabul ettiğimiz müteselsil borçlular açısından bu müteselsil sorumluluğunun hangi miktarda olacağının da ele alınması gerekir. Kanaatimizce aşkın zarar açısından kabul edilmesi gereken müteselsil sorumluluğun miktarı, en fazla temerrüt faizini ödeyen müteselsil borçlunun ödediği miktarı aşan zarar tutarında olmalıdır. Yoksa somut olayda daha az temerrüt faizi ödemekle yükümlü olan müteselsil borçlunun ödediği miktarı aşan miktar esas alınmamalıdır. Aksinin kabulü alacaklının haksız biçimde

\footnotetext{
155 Eren (n 1) 1134. Ayrıca bkz. Hasan Ayrancı, Türk Borçlar Hukukunda Munzam Zarar (BK m 105) (Yetkin 2006) "115ff”.

$156 \mathrm{Bu}$ madde bakımından karşılanması gereken zarar; temerrüt gerçekleşmeksizin borçlunun borcunu ödemesi halinde alacaklının malvarlığının içinde bulunacağı durum ile temerrüt nedeniyle içinde bulunulan durum arasında söz konusu olacak farkın temerrüt faizi tutarını aşan kısmı olacaktır (Barlas (n 145) 189).

157 Aşkın zararın talep edilebilme şartları hakkında ayrıntılı bilgi için bkz. Ayrancı (n 155) "123ff”.
} 
zenginleşmesine yol açacak nitelik taşır. Taraflar aynı tarihte temerrüde düşmüşler ve aynı temerrüt faizi oranına tabi iseler özellik arz eden bir durumla karşılaşılmaz ise de farklı tarihlerde temerrüde düşme veya farklı faiz oranına tabi olma durumları bakımından kabul ettiğimiz görüş bakımından özellik arz eder.

Durumu bir örnekle somutlaştıralım. İlk olarak temerrüt tarihinin ve faiz oranlarının aynı oluşunu ele alalım. Dört adet müteselsil borçlulardan ikisi olan A ve B'nin kusurları ile sözleşme konusu bedeli ödemede aynı tarihte temerrüde düştüklerini ve haklarında aynı temerrüt faizi oranının geçerli olduğunu varsayalım. Bu durumda A ve B açısından 2.000 TL temerrüt faizi işlediğini, alacaklının bunu aşan $3.000 \mathrm{TL}$ zararının olduğunu kabul edelim. Bu halde aşan kısım olan 3.000 TL'den A ve B müteselsilen sorumlu olur.

İkinci olarak alacaklılar için söz konusu olan faiz oranlarının aynı olmasına karşın A'nın temerrüde B'den daha erken düştüğünü varsayalım. Buna göre A açısından 4.000 TL temerrüt faizi işlemişken B açısından ise 2.000 TL'lik bir temerrüt faizi işlemiş alacaklının da gecikme nedeniyle toplamda 10.000 TL'lik bir zararının olduğunu kabul edelim. Bu durumda yukarıda temerrüt faiz bakımından kabul ettiğimiz görüşe göre A ve B faiz bedelinin ödenmesinin 2.000 TL'lik kısmından müteselsilen sorumlu olacak A kalan 2.000 TL'lik kısım için tek başına sorumlu olacak, diğer bir ifade ile bu kısım için alacaklı sadece A'ya başvurabilecektir. Bu durumda aşkın zararın da 10.000$4.000=6.000$ TL olduğunu kabul etmek ve bu 6.000 TL'den A ve B'nin müteselsilen sorumlu olacağını kabul etmek gerekir. Aksi takdirde, yani B için işlemiş olan 2.000 TL'lik temerrüt faizini aşan kısım olan 10.000-2.000=8.000 TL'yi aşkın zarar kabul ederek bunlardan A ve B'yi müteselsil sorumlu tutmak ise alacaklıyı zenginleştirmek anlamına gelecektir. Zira bu durumda $2.000 \mathrm{TL}$ temerrüt faizi açısından A ve B'ye müteselsilen, kalan 2.000 TL'lik temerrüt faizi için A'ya tek başına başvurabilen alacaklının 8.000 TL'lik alacağ alacaklının toplamda 2.000 TL+2.000 TL+8.000 TL=12.000 TL elde etmesine sebep olur. $\mathrm{Bu}$ nedenle aşkın zarardan müteselsil sorumluluğun işlemiş temerrüt faizinden yüksek olanı aşan kısım bakımından olduğunu kabul etmek gerekir.

\section{Temerrüdün Karşılıklı Borç Yükleyen Sözleşmelerdeki Sonuçları Bakımından}

\section{Genel Olarak}

Karşılıklı borç yükleyen sözleşmeler, edim ve karşı edim arasında değişim ilişkisinin bulunduğu ve sözleşmenin taraflarının karşıllklı olarak borçlu ve alacaklı olduğu sözleşmelerdir ${ }^{158}$. TBK m 123-126 arasında karşılıklı borç yükleyen sözleşmelerde

58 Eren (n 1) 1137. Ayrica bkz. Tunçomağ (n 4) 931; Feyzioğlu (n 7) 253; Gauch, Schluep and Emmenegger (n 9) para. 2731. 
borçlu temerrüdüne ilişkin düzenlemelere yer vermiş̧tir. TBK m $125^{`}$ te karş1l1klı borç yükleyen bir sözleşmede temerrüde düşülmesi üzerine alacaklının diğer sözleşmelere nazaran ayrıca sahip olduğu seçimlik haklara yer verilmiş, TBK m 126'da bu husus sürekli edimli sözleşmelerin arz ettiği özellik göz önüne alınarak düzenlenmiştir. TBK m 123 ve m 124'te ise bu hakları kullanabilmek için borçluya verilmesi gereken ek süre ve bu ek sürenin verilmesinin gerekmediği hallere yer verilmiştir. Aşağıda bu hallerin bütün özelliklerine yer verilmeyip, müteselsil borçluluk açısından önem arz ettiği ölçüde ele alınacaktır.

\section{Borçluya Ek Süre Verilmesi, Süre Verilmesini Gerektirmeyen Haller ve Alacaklının Seçim Hakkı}

Karşlıklı borç yükleyen bir sözleşmede alacaklının TBK m 125 ve TBK m 126'daki imkânlardan yararlanabilmesi için kural olarak borçluya ek bir süre vermesi veya bu sürenin verilmesini hâkimden talep etmesi gerekir.

Süre verme, alacaklının temerrüde düşmüş olan borçlunun borcunu ifa etmesi amacına matuf olarak borçluya süre tanıması olarak ifade edilebilir ${ }^{159}$. Bu şekilde bir süre verilmesinin amacı, karşı1lılı borç yükleyen sözleşmelerdeki temerrüdün ağır sonuçlarından borçlunun kurtulabilmesi için, borçluya son bir imkân tanımaktır ${ }^{160}$. Alacaklının bu süreyi vermesi hukuki işlem benzeri bir fiil niteliğini haizdir ${ }^{161}$. TBK m 123 uyarınca verilecek sürenin uygun bir süre olması da şarttı1 ${ }^{162}$. Sürenin verilmesi herhangi bir şekil şartına tabi değildir ${ }^{163}$. Ancak tacirler arasında verilecek ek süre açısından TTK m 18/f. 3'e uyulması gerekirr' ${ }^{164}$.

Seçimlik hakları kullanmak için kural ek süre verilmesi iken TBK m 124'te sayılan hallerde ise istisnai olarak ek süre verilmesine gerek olmaz. Bu haller; borçlunun içinde bulunduğu durumdan ve tutumundan süre verilmesinin etkisiz olduğunun anlaşılması (b. 1), borçlu temerrüdü sonrası borcun ifasının alacaklı açısından yararsız kalması (b. 2), borcun ifasının belirli bir zamanda veya belirli bir süre içinde gerçekleşmemesi üzerine, ifanın kabul edilmeyeceğinin sözleşmeden anlaşılması (b. 3) halleridir.

\footnotetext{
159 Oğuzman and Öz, Borçlar Hukuku Genel Hükümler C. 1 (n 2) para. 1651. Ayrica bkz. Tekinay and others (n 2) 946.

160 Kılıçoğlu (n 9) 886; Tunçomağ (n 4) 934; Saymen and Elbir (n 10) 750. Ayrıca bkz. Büren (n 7) 374; Tuhr and Escher (n 7) 148; Keller and Schöbi Christian, Keller, Max/Schöbi, Christian, Das Schweizerische Schuldrecht, B. 1, Allgemeine Lehren des Vertragrechts (n 68) 271.

161 Tekinay and others (n 2) 946; Tunçomağ (n 4) 935; Reisoğlu (n 4) 384; Kılıçoğlu (n 9) 872; Tuhr and Escher (n 7) 149; Bucher (n 4) 367; Schwenzer (n 4) para. 66.16; Keller and Schöbi Christian, Keller, Max/Schöbi, Christian, Das Schweizerische Schuldrecht, B. 1, Allgemeine Lehren des Vertragrechts (n 68) 271.

${ }_{162}$ Uygun süre verilmemesi halinde bunun sonucunun ne olacağı doktrinde tartışmalıdır. Bkz. Oğuzman and Öz, Borçlar Hukuku Genel Hükümler C. 1 (n 2) para. 1659; Büren (n 7) 375.

163 Eren (n 1) 1139; Oğuzman and Öz, Borçlar Hukuku Genel Hükümler C. 1 (n 2) para. 1661; Tercier, Pichonnaz and Develioğlu (n 2), §25, para. 1309; Feyzioğlu (n 7) 256; Reisoğlu (n 4) 384; Gauch, Schluep and Emmenegger (n 9) para. 2735; Schwenzer (n 4) para. 66.16.

164 Oğuzman and Öz, Borçlar Hukuku Genel Hükümler C. 1 (n 2) para. 1661.
} 
Müteselsil borçlulukta alacaklı ancak temerrüde düşen müteselsil borçluya ek süre verebilir ${ }^{165}$. Verilen bu ek süre, sadece kendisine ek süre verilen müteselsil borçlu açısından sonuç doğurur ${ }^{166}$. Bu husus alacaklının bir borçluya yönelen davranışı ile diğerlerinin durumunu ağırlaştıramamasına yönelik temel prensibe dayanır. Buna göre karş1lıklı borç yükleyen bir sözleşmede temerrüde düşen bir müteselsil borçluya karşı TBK m 125'teki ek imkânları kullanmak isteyen alacaklının, temerrüde düşen müteselsil borçluya vermiş olduğu ek süre, sadece onun açısından sonuç doğurur. $\mathrm{Bu}$ husus temerrüde düşen müteselsil borçluların sayısının birden fazla olması halinde de kural olarak aynıdır. Alacaklı temerrüde düşen her bir müteselsil borçluya ayrı ayrı uygun ek süreler vermek durumundadır. Bu noktada ek sürenin alacaklı tarafından yetkili temsilciye de verilebileceğ ${ }^{167}$ hususu da göz önünde bulundurulmalıdır. Buna göre temerrüde düşen müteselsil borçluların birbirlerini temsil yetkisi bulunmakta ise bu durumda bir borçluya verilen ek sürenin diğerleri açısından da sonuç doğuracağı kabul edilebilir ${ }^{168}$. Ancak bu durumda dahi, kanaatimizce alacaklının ek süre verme iradesini içeren beyanını kime yönelttiği önemlidir. Temerrüde düşen müteselsil borçluların birbirlerini temsil yetkisi bulunsa dahi, alacaklının müteselsil borçlulardan hangisine ek süre verdiğini beyanında belirtmemesi halinde, bu beyana doğrudan muhatap olan müteselsil borçlu açısından hüküm ifade etmesi gerektiği kabul edilmelidir. Alacaklı beyanda bulunduğu müteselsil borçlu ile birlikte diğerine de ek süre vermek niyetinde ise bunu açık olarak iradesini yönelttiği müteselsil borçluya beyan etmelidir.

TBK m 123 uyarınca borçlulara verilmesi gereken sürenin uygun bir süre olmas1 gerekmektedir. Müteselsil borçlular birbirinden nispi olarak bağımsız olduğu için temerrüde düşmüş olan her bir müteselsil borçlu açısından verilmesi gereken ek sürenin uygunluğu ayrı değerlendirilmelidir. TBK m 123 gereğince verilecek sürenin dürüstlük kuralı temelinde taraflarının menfaatlerinin dikkate alınarak belirlenmesi gerekir ${ }^{169}$. Hal böyle olunca somut olaydaki değerlendirmeye göre bir borçluya verilmiş olan ek süre uygun olabilirken, diğer bir borçlu açısından aynı ek süre uygun olmayabilir. Her bir müteselsil borçlunun ifayı hazırlamak için içinde bulunduğu şartlar ve sahip olduğu imkânlar birbirinden farklılık arz edebilir. Bu nedenle örneğin bir borçluya bir haftalık bir ek süre verilmesi uygun olabilecek iken diğer bir müteselsil borçlu daha uzun veya daha kısa bir süre uygun süre olarak değerlendirilebilir.

Yine müteselsil borçluların alacaklı karşısındaki borçlarının birbirinden nispi olarak bağımsız olmasının bir sonucu olarak, temerrüde düşmüş bazı müteselsil borçlulara TBK m 123 uyarınca uygun bir ek süre vermek gerekebilir iken diğer

\footnotetext{
$\overline{165}$ Tuhr and Escher (n 7) 307; Mazan (n 7), Art. 146, para. 4.

166 Benzer şekilde bkz. Arsebük (n 13) 1015; Canyürek (n 7) 41; Kapancı (n 5) 158-159; Mazan (n 7), Art. 146, para. 4; Krauskopf (n 7), Art. 146, para. 85.

167 Eren (n 1) 1139.

168 Benzer şekilde bkz. Krauskopf (n 7), Art. 146,para. 85.

169 Oğuzman and Öz, Borçlar Hukuku Genel Hükümler C. 1 (n 2) para. 1656.
} 
bazıları açısından TBK m 124 hükmü gereği ek süre verilmesine gerek olmayabilir. Bunun yanı sıra temerrüde düşmüş olan müteselsil borçlular bakımından da ek süreyi gerektirmeyen sebepler birbirinden farklı olabilir. Söz gelimi temerrüde düşen müteselsil borçlulardan birinin tutumu sebebiyle süre vermenin etkisiz olmasından dolayı (TBK m 123/b. 1 gereği) ona süre vermek gereksiz olabilecek iken, temerrüde düşen diğer bir müteselsil borçlu açısından ise ifanın belirli zamanda gerçekleşmemesi üzerine ifanın kabul edilmeyeceği sözleşmeden anlaşıldığ 1 için (TBK m 123/b. 3 gereği) süre vermek gereksiz olabilir. TBK m 123/b. 2'de belirtilen durum ise müteselsil borçluların borçlandığı edimin konusu aynı ise bütün borçlular açısından geçerli olur. Diğer bir deyişle bu ihtimalde bütün temerrüde düşen borçlular için aynı sebep ile süre verilmesinin gereksiz olması söz konusu olur. Zira söz konusu bentte ifanın alacaklı için yararsız kalması hali düzenlenmiştir. İfanın alacaklı için yararsız kalması hali söz konusu ise bu durumda bütün temerrüde düşmüş borçlular açısından aynı sebeple ek süre verilmesine gerek olmayan bir hal söz konusu olur. Ancak temerrüde düşen müteselsil borçluların edimleri farklı farklı ise, bu halde müteselsil borçlulardan birinin edimi ifasında alacaklının menfaati kalmamış olsa bile diğer edimi elde etmede menfaatinin olması söz konusu olabilir.

Verilen ek süre boyunca da borç ifa edilmemişse veya süre verilmesi gerekmeyen bir durum bulunmakta ise alacaklının ifa ve gecikme tazminatını istemeye devam edebileceği TBK m 125/f. 1'de belirtilmiştir ${ }^{170}$.

Bu imkânın dışında alacaklının TBK m 125/f. 2'deki haklarını kullanması da mümkündür. Alacaklının bunun için sürenin sonunda kullanmak istediği hakk1 borçluya derhal beyan etme zorunluluğu mevcuttur ${ }^{171}$. Alacaklının seçim hakkı yenilik doğuran bir hak olup ${ }^{172}$; seçtiği yolu borçluya beyan etmesi ise yenilik doğuran bir işlem teşkil eder ${ }^{173}$. Borçluya alacaklının bu beyanının ulaşması ile beyan hüküm ifade edecek olup, borçlunun öğrenmesinden sonra alacaklı tarafindan bu beyandan dönülmesi söz konusu olmaz ${ }^{174}$.

Alacaklı temerrüde düşen müteselsil bir borçluya karşı bu seçim hakkını kullandığında söz konusu etki sadece bu beyanın yöneldiği müteselsil borçlu açısından söz konusu olur ${ }^{175}$. Temerrüde düşmüş müteselsil borçluya alacaklı seçtiği hakkı beyan etmesiyle artık temerrüde düşen müteselsil borçlu açısından bu sonuç doğmuş olur.

\footnotetext{
$\overline{170} \mathrm{Bu}$ durumda müteselsil borçluluk açısından özellik arz eden hususlarda yukarıda gecikme tazminatına ilişkin olarak yaptı̆̆ımız açıklamalar geçerlidir. Bkz. V. B. 1.

171 Oğuzman and Öz, Borçlar Hukuku Genel Hükümler C. 1 (n 2) para. 1667; Tercier, Pichonnaz and Develioğlu (n 2), §25, para. 1311; Saymen and Elbir (n 10) 751. Derhal beyan etmekten, somut olayın şartları ve niteliği ile dürüstlük kuralları dikkate alındığında gecikmemek anlaşılmalıdır, Kılıçoğlu (n 9) 928.

172 Kılıçoğlu (n 9) 927; Furrer and Müller-Chen (n 14) 607.

173 Oğuzman and Öz, Borçlar Hukuku Genel Hükümler C. 1 (n 2) para. 1671.

174 Oğuzman and Öz, Borçlar Hukuku Genel Hükümler C. 1 (n 2) para. 1673.

175 Koller (n 7), para. 75.147; Eren (n 1) 1236; Arat (n 7) 359. Benzer şekilde bkz. Tuhr and Escher (n 7) 307.
} 


\section{3. İfadan Vazgeçerek Olumlu Zararın Tazmini}

Karşılıklı borç yükleyen bir sözleşmede borçlunun temerrüdü halinde TBK m 125/f. 2 uyarınca alacaklı ifadan vazgeçerek, borcun ifa edilmemesinden doğan zararının tazmin edilmesini talep edebilir. Alacaklının talep edebileceği bu zarar olumlu zarardı1 ${ }^{176}$. Bu zararın tazmininin talep edilebilmesi için borçlunun kusurlu olması gerekir ${ }^{177}$. Bu zararın tazmini bakımından kusurlu ifa imkânsızlığına ilişkin hükümler uygulama alanı bulur ${ }^{178}$.

Alacaklının temerrüt sonucunda ifadan vazgeçerek olumlu zararının tazminini istemesi durumunda, bu tazminatın belirlenmesinde dikkate alınan mübadele ve fark teorileri ${ }^{179}$ dikkate alınarak, bu zararın istenip istenemeyeceği ve istenebilecek ise bunun ne şekilde olacağ 1 konusunda bir ayrım yapılmalıdır ${ }^{180}$. Müteselsil borçlulardan sadece biri temerrüde düşmüş ise alacaklı bu temerrüde düşen borçlunun ifasından vazgeçerek bu müteselsil borçludan mübadele teorisi uyarınca tazminat talep edilebilir. Zira bu durumda alacaklı bu durumda kendi edimini müteselsil borçlulardan birine karşı yerine getirebilecek durumdadır ve ifasından vazgeçilmiş olan müteselsil borçlunun tazminat ödeme yükümlülüğünün meydana gelmesi diğer müteselsil borçluların durumunu ağırlaştırmaz ${ }^{181}$.

Alacaklının olumlu zararının tazminini fark teorisi uyarınca isteyebilmesi için ise doktrinde bir görüşe göre ${ }^{182}$ alacaklı tarafından bütün borçlulara süre tayin edilmesi ve ifadan vazgeçildiği bildiriminin yapılması gerekir. Bunun gerekçesi ise fark teorisine göre tazminat talep edildiğinde, sadece kendisine karşı ifadan vazgeçilmek suretiyle tazminat talep edilen borçlunun değil, diğer müteselsil borçluların da karşı edimi isteme haklarını yitirmeleridir. Bu görüşe göre bunun aksinin kabul edilmesi halinde böyle bir durumda bir müteselsil borçlu verilen süre içinde borcunu ifa etmemek suretiyle diğer müteselsil borçluların durumunu ağırlaştırmış olur.

\footnotetext{
176 Kılıçoğlu (n 9) 930; Tekinay and others (n 2) 962; Tercier, Pichonnaz and Develioğlu (n 2), §25, para. 1317; Erdoğan (n 1) 229; Ayşe Havutçu, Tam İki Tarafa Borç Yükleyen Sözleşmelerde Temerrüt ve Müsbet Zararın Tazmini (Dokuz Eylül Üniversitesi Hukuk Fakültesi Döner Sermaye İșletmesi Yayınları 1995) 67; Furrer and Müller-Chen (n 14) 611; Schwenzer (n 4) para. 66.27; Keller and Schöbi Christian, Keller, Max/Schöbi, Christian, Das Schweizerische Schuldrecht, B. 1, Allgemeine Lehren des Vertragrechts (n 68) 275. Bu zarar kalemleri için bkz. Kılıçoğlu (n 9) 930; Eren (n 1) 1145; Havutçu (n 176) 74-75; Gauch, Schluep and Emmenegger (n 9) para. "2769ff”; Furrer and Müller-Chen (n 14) 611-612.

177 Oğuzman and Öz, Borçlar Hukuku Genel Hükümler C. 1 (n 2) para. 1677.

178 Eren (n 1) 1147; Tunçomağ (n 4) 949; Tuhr and Escher (n 7) 154. Ayrıca bkz. Tekinay and others (n 2) 962.

179 Mübadele teorisinde, olumlu zararın tazminini isteyen alacaklı kendi edimini yerine getirmesi söz konusu iken, fark teorisinde alacaklı kendi edimini aynen yerine getirmek zorunda olmayıp, kendi edimini borçlunun ödeyeceği tazminat miktarından düşürür ve aradaki farkı talep eder, bkz. Havutçu (n 176) 77. Bu teoriler hakkında bilgi için ayrıca bkz. Eren (n 1) 1146; Oğuzman and Öz, Borçlar Hukuku Genel Hükümler C. 1 (n 2) para. "1298ff”; K1lıçoğlu (n 9) 933-934; Havutçu (n 176) "76ff”; Büren (n 7) "376ff”; Gauch, Schluep and Emmenegger (n 9) para. "2777ff”; Keller and Schöbi Christian, Keller, Max/Schöbi, Christian, Das Schweizerische Schuldrecht, B. 1, Allgemeine Lehren des Vertragrechts (n 68) 275; Kramer and Probst (n 3) para. 496.

${ }^{180} \mathrm{Bu}$ şekilde bir ayrıma gitmeksizin bu hakkın ancak temerrüde düşen müteselsil borçluya karşı kullanılabileceği yönünde bkz. Tuhr and Escher (n 7) 307.

181 Havutçu (n 176) 113.

182 ibid 113 ve orada dn 75 'te belirtilen yazarlar.
} 
Kanaatimizce temerrüde düşmüş olan müteselsil borçlu veya borçlulardan fark teorisi uyarınca olumlu zararın istenebilmesi için her zaman bütün borçlulara süre tayin edilmesi ve ifadan vazgeçildiği bildiriminin yapılması gerekli değildir. $\mathrm{Bu}$ noktada önem arz eden husus fark teorisine göre olumlu zararı isteyecek olan alacaklının, karşı edimini yerine getireceği müteselsil borçlu veya borçluların kim olduğudur. Müteselsil borçluların tamamının, alacaklıdan bir karşı edim alacağı olduğu hallerde, alacaklı temerrüde düşmüş olan tek bir müteselsil borçludan yukarıda da belirtildiği üzere ifadan vazgeçilerek olumlu zararın tazminini talep edememelidir. Zira bu durumda diğer müteselsil borçlular karşı edim alacağını kaybetmiş ve böylece durumları ağırlaşmış olur. Ancak alacaklının karşı edimini yerine getirmesi gereken sadece bir veya birkaç müteselsil borçlu söz konusu ise (bütün müteselsil borçlular karşı edim alacaklısı değil ise) bu durumda bütün müteselsil borçluların temerrüde düşmesini, bunların tamamına ek süre vermeyi ve bunların tamamına ifadan vazgeçildiği bildirimi yapılmasını gerektirecek haklı bir menfaat bulunmamaktadır. Böyle durumlarda alacaklının fark teorisine göre olumlu zararını isteyebilmesi için karşı edim alacaklısı olan müteselsil borçlunun veya borçluların temerrüde düşmüş olması yeterlidir. Karşı edim alacaklısı olmayan, diğer bir deyişle sadece müteselsil borçlu olarak bulunanların böyle bir hal karşısında durumunun ağırlaştığından da söz etmek mümkün değildir. Örneğin bir müteselsil borçlu temerrüde düştüğünde bu borç ilişkisi içinde, alacaklıdan talep edilecek karşı edim alacağını da sadece bu müteselsil borçlu talep edebilecek ise bu durumda sadece bu müteselsil borçludan fark teorisine göre olumlu zararın tazmini talep edilebilir. Diğer müteselsil borçluların zaten bir alacağı olmadığından, durumlarının kötüleştiğinden de bahsedilemez.

Alacaklı temerrüde düşmüş olan kusurlu müteselsil borçluya karşı ifadan vazgeçip olumlu zararın tazminini talep ettiğini beyan etmiş ise artık bu müteselsil borçludan ifayı talep edemez ${ }^{183}$. Şayet alacaklı temerrüde düşmüş olan müteselsil borçluya karşı bir edim yükümlülüğü altında değil ise uğradığı zararın tamamının tazminini isteyebilir ${ }^{184}$.

183 Böyle bir halde temerrüde düşmemiş olan borçlu başlangıçtaki edimini ifa ederek borçtan kurtulabilir (Arsebük (n 13) 1015).

184 Doktrinde Dağdelen, temerrüde düşen müteselsil borçluya karşı alacaklının ifadan vazgeçerek olumlu zararının tazminini istediğinde, bu borçlunun teselsül ilișkisine dahil olan borcunun sona ereceğini, bu sona ermeden de diğer borçluların TBK m 166/f. 2 uyarınca yararlanacakları ve olumlu zararın hesaplanmasında da bunun dikkate alınacağını ifade etmiştir. Yazara göre örneğin, 1000 TL değerinde 100 kasa portakalın teslimini müteselsilen borçlanan iki borçludan birine karşı, temerrüdü nedeniyle ifadan vazgeçilerek olumlu zararın talep edilmesi durumunda, temerrüde düşen borçlunun borcu sona erer. İç ilişkide bu borçlunun sorumlu olduğu teslim miktarı 70 kasa ise diğer borçlunun borcu da 100 kasa portakal tesliminden 30 kasa portakal teslimine düşer. Alacaklının olumlu zararı ise 70 kasa portakalın değeri olan 700 TL ve diğer giderleridir. Bkz. Dağdelen (n 9) 107. Yazara göre, temerrüde düşen borçlunun sona ermeyip şekil değiştirdiği kabul edilirse, bu durumda diğer borçluların alacaklı karşısındaki durumları değişmez. Diğer borçlular başlangıçta borçlandıklarını ifa ile yükümlü olmaya devam ederler. Mütemerrit borçludan tazminat elde edilmesi durumunda diğer borçluların borcu da sona erer ve tazminat da ifa halindeki durum ile ifa etmeme durumu arasındaki farka göre belirlenir. bkz. Dağdelen (n 9) 108. Kanaatimizce alacaklıya taraflar arasındaki iç ilişkiyi bilemeyeceği gibi bu şekilde bir zorunluluğu da yoktur. Ayrıca müteselsil borçluların edimlerinin birbirinden farklı olması durumunda söz temerrüde düşmemiş olan borçlunun borcunun ne şekilde indirileceği hususu da önemli problemler oluşturabilecektir. Bu nedenle bizim yukarıda belirttiğimiz ve yazarın da ikinci olarak belirttiği hususun kabulü meseleyi daha basit olarak çözebilecektir. 
Alacaklı müteselsil borçlulardan birini temerrüde düşürüp olumlu zararını isteyebilecek durumu oluşturduğunda, hem temerrüde düşen borçludan olumlu zararını içeren tazminatı hem de diğer müteselsil borçlulardan başlangıçta kararlaştırılan edimi isteyemez, bunlardan ancak birini tercih etmek durumundadir ${ }^{185}$. Bu noktada dikkat çekilmesi gereken bir husus, şartları gerçekleştiğinde müteselsil borçlulardan birine karşı ifadan vazgeçip olumlu zararın talep edilmesinin, diğer müteselsil borçluları etkilememesidir. $\mathrm{Bu}$ noktada temerrüde düşmemiş diğer borçlular sözleşmedeki edimi yerine getirerek borcu sona erdirirler ${ }^{186}$ ise diğer borçlulardan söz konusu olumlu zararın tazmini istenemez ${ }^{187}$. Kanaatimizce bu durumda alacaklının ifadan vazgeçme sebebiyle söz konusu olabilecek olumlu zararı temerrüde düşmüş ve kendisine karşı ifadan vazgeçildiği beyan edilmiş olan müteselsil borçludan istenmesi de mümkün olmaz ${ }^{188}$. Zira burada alacaklının talep edebileceği olumlu zarar ifanın yerini almaktadır. Aksi durumda alacaklı hem ifayı hem de ifaya olan menfaatini elde etmiş olur. Diğer taraftan temerrüde düşmüş olan müteselsil borçlu kendisine karş1 ifadan vazgeçerek olumlu zararını talep eden alacaklının bu zararını tazmin ederse, diğer müteselsil borçluların da borcu sona ermiş olur ${ }^{189}$.

Birden fazla müteselsil borçlunun temerrüde düşmesi ve alacaklının bunların tamamına karşı ifadan vazgeçerek olumlu zararının tazmini talebinde bulunması halinde kanaatimizce mütemerrit müteselsil borçluların olumlu zararın tazmininden de mütesesilen sorumlu oldukları kabul edilmelidir.

\section{Sözleșmeden Dönme ve Olumsuz Zararın Tazmini}

Alacaklının borçluya vermiş olduğu ek süre sonucunda borcunu ifa etmediği (veya ek sürenin gerekmediği) hallerde sahip olduğu diğer bir imkân TBK m 125/f. 2'de belirtilen sözleşmeden dönme hakk1dır ${ }^{190}$. Sözleşmeden dönmenin sonuçları ise TBK m 125/f. 3'te belirtilmiştir. Buna göre, "Sözleşmeden dönme hâlinde taraflar, karşılıkl olarak ifa yükümlülüğ̈̈nden kurtulurlar ve daha önce ifa ettikleri edimleri geri isteyebilirler. Bu durumda borçlu, temerrüde düşmekte kusuru olmadiğını ispat edemezse alacaklı, sözleşmenin hükümsüz kalması sebebiyle uğradı̆̆ zararın giderilmesini de isteyebilir". Görüldüğ̈̈ üzere hükümde sözleşmeden dönmenin tarafların edimleri ifa yükümlülüğünden kurtardığı ve ifa etmişler ise iade talep

\footnotetext{
185 Benzer şekilde bkz. Krauskopf (n 7), Art. 146, para. 86.

186 Tuhr and Escher (n 7) 307.

187 Şahin Caner (n 7) 245; Canyürek (n 7) 41.

188 Aksi görüşte bkz. Arsebük (n 13) 1015, fn. 67.

189 Kanaatimizce olumlu zararı tazmin eden mütemerrit borçlu ödediği tazminatın tamamını diğer müteselsil borçlulara rücu edememeli, temerrüde düşmemiş olan müteselsil borçlulara edimin değerinden onların iç ilişkideki payları oranında rücu edebilmelidir. Aksinin kabulü edimin değerinden daha fazlasını tazmin etmiş olan müteselsil borçlunun bu durumu diğer müteselsil borçlulara yansıtması suretiyle onların durumunu ağırlaştırması anlamına gelir ve TBK m 165'e aykırılık teşkil eder.

190 Konu hakkında ayrıntılı bilgi için bkz. Rona Serozan, Sözleşmeden Dönme (2nd edn, Vedat Kitapçılık 2007) "7ff”; Vedat Buz, Borçlunun Temerrüdünde Sözleşmeden Dönme (Tıpkı Basım, Yetkin 2014) “45ff”.
} 
edebilecekleri düzenlenmiştir. Ayrıca borçlunun kusursuzluğunu ispatlayamadığ1 hallerde alacaklının sözleşmeden dönme sebebiyle uğradığı zararı da talep edebileceği ifade edilmiştir.

Sözleşmeden dönmenin etkisi tartışmal ${ }^{191}$ olmakla birlikte kabul ettiğimiz klasik dönme görüşüne göre sözleşmeden dönme ile birlikte sözleşme ilişkisi kurulduğu andan itibaren geçmişe etkili olarak ortadan kalkar ${ }^{192}$. Alacaklının sahip olduğu dönme hakk1 bozucu yenilik doğuran bir hak teşkil eder ${ }^{193}$. Sözleşmeden dönme üzerine artık tarafların birbirinden ifa talep etmesi mümkün olmaz ${ }^{194}$. Sözleşmeden dönme ile tarafların önceden verdikleri veya yaptıklarının artık hukuki sebebi ortadan kalkar ${ }^{195}$. Tarafların ifa ettikleri edimlerini ise sebepsiz zenginleşme hükümlerine göre birbirlerine iade etmeleri gerekir ${ }^{196}$. Buna göre gerek iade yükümlülüklerine gerekse buna ilişkin zamanaşımı süresine sebepsiz zenginleşme hükümleri uygulanır.

Sözleşmeden dönme üzerine borçlu uğramış olduğu olumsuz zararının tazminini talep edebilir. $\mathrm{Bu}$ zarar sözleşmeden dönme sebebiyle alacaklının uğramış olduğu zararı ifade eder ${ }^{197}$. Bu zarar alacaklının sözleşmenin yapılmış olmaması halinde uğranılmayacak olan zararları içerir ${ }^{198}$. Bu zararın talep edilebilmesi için TBK m 125/f. 3’ten de anlaşıldığı üzere borçlunun kusuru gerekmektedir.

Sözleşmeden dönme dar anlamda borcu değil, geniş anlamda borç iliş̧isini sona erdiren hallerden biridir. $\mathrm{Bu}$ nedenle doktrinde isabetli olarak müteselsil borç ilişkisinde alacaklının sözleşmeden dönebilmesi için bütün borçluların temerrüde düşmüş olması gerektiği ifade edilmektedir ${ }^{199}$. Buna göre alacaklının sözleşmeden dönebilmesi için bütün borçluların temerrüde düşmüş olması, TBK m 124'te belirtilen

\footnotetext{
191 Sözleşmeden dönmenin etkisi hakkında savunulan görüşler için bkz. Eren (n 1) "1148ff”; Oğuzman and Öz, Borçlar Hukuku Genel Hükümler C. 1 (n 2) para. "1689ff"; M. T Öz, 'Borçlu Temerrüdünde Sözleşmeden Dönmenin Bu Sözleşme Gereğince Kazanılmış Ayni Haklara Etkisi ve Klasik Dönme Kuramı ile Yeni Dönme Kuramının Kısa Bir Karşılaştırmalı Eleştirisi' [13] MHAD 131 "133ff”; Buz (n 190) "118ff”; Serozan (n 190) “59ff”.

192 Oğuzman and Öz, Borçlar Hukuku Genel Hükümler C. 1 (n 2) para. 1690; Tunçomağ (n 4) 951; Saymen and Elbir (n 10) 756; Tuhr and Escher (n 7) 155; Öz (n 191) 134.

193 Hatemi and Gökyayla (n 1), §26, para. 90; Eren (n 1) 1148; Öz (n 191) 134. Eren (Eren (n 1) 1150) ve Hatemi ve Gökyayla (Hatemi and Gökyayla (n 1), §26, para. 92), yeni dönme görüşünü, Öz ise ayni etkili dönme görüşünü (Öz (n 191) 172) benimsemektedir.

194 Tuhr and Escher (n 7) 155; Oğuzman and Öz, Borçlar Hukuku Genel Hükümler C. 1 (n 2) para. 1690.

195 Oğuzman and Öz, Borçlar Hukuku Genel Hükümler C. 1 (n 2) para. 1690.

196 Eren (n 1) 1149; Kılıçoğlu (n 9) 936.

197 Eren (n 1) 1152.

198 Kılıçoğlu (n 9) 930-931. Bu zarar kalemleri için bkz. Kılıçoğlu (n 9) 931; Oğuzman and Öz, Borçlar Hukuku Genel Hükümler C. 1 (n 2) para. 1706; Tunçomağ (n 4) 956; Reisoğlu (n 4) 390-391; Tuhr and Escher (n 7) 156-157; Furrer and Müller-Chen (n 14) 611; Keller and Schöbi Christian, Keller, Max/Schöbi, Christian, Das Schweizerische Schuldrecht, B. 1, Allgemeine Lehren des Vertragrechts (n 68) 279.

199 Akıntürk (n 7) 200; Funk (n 7) 214; Oser and Schönenberger (n 5) 911; Velidedeoğlu and Özdemir (n 7) 314; Canyürek (n 7) 41; Saymen and Elbir (n 10) 786; Buz (n 190) 296-297; Kapancı (n 5) 159; Şahin Caner (n 7) 245; Arat (n 7) 359; Mazan (n 7), Art. 146, para. 4; Bucher (n 4) 495, fn. 42; Keller and Schöbi Christian, Das Schweizerische Schuldrecht, B. 4, Gemeinsame Rechtsinstitute für Schuldverhältnisse aus Vertrag, unerlaubter Handlung und ungerechtfertigter Bereicherung (n 7) 11; Graber (n 7), para. 3; Gauch, Schluep and Emmenegger (n 9) para. "3725ff"; Gautschi (n 8) para. 14; Huguenin (n 3) para. 2305; Becker (n 9), Art. 146, para. 2; Tuhr and Escher (n 7) 307; Berger (n 5) para. 2424; Müller (n 7), Art. 146, para. 1; Kratz (n 9), Art. 146, para. 33; Jung (n 9), Art. 146, para. 2.
} 
istisnai bir durum olmadıkça alacaklının müteselsil borçlulara TBK m 123'te öngörülen uygun ek süreyi vermesi gerekir. Alacaklının tek bir müteselsil borçluya karşı sözleşmeden dönme beyanında bulunması diğer müteselsil borçluların da içerisinde bulunduğu sözleşmeden doğan borç ilişkisini ortadan kaldırmaz. Aksinin kabulü gerek müteselsil borçlulardan birinin davranışından (borcu ifa etmemek suretiyle temerrüde düşme), gerekse alacaklının davranışından (sözleşmeden dönme bildirimi) dolayı, diğer müteselsil borçluların durumunu ağırlaştırmak anlamına gelir. Zira diğer söz konusu durumda henüz diğer müteselsil borçluların temerrüdü dahi söz konusu olmaksızın sözleşme ilişkisinin dışında kalmaları söz konusu olur. Ayrıca temerrüde düşmemiş olan müteselsil borçlular, alacaklıdan bir karşı edim alacaklısı iseler sözleşmeden dönme durumunda bunu da kaybederler ki bunun kabul edilebilmesi isabetli olmaz ${ }^{200}$.

Bütün müteselsil borçlular açısından sözleşmeden dönmenin şartları oluşmamış olsa da alacaklı temerrüde düşmüş ve kendisine verilen ek süre boyunca da ifa etmeyen münferit bir müteselsil borçluya sözleşmeden dönme beyanında bulunmuş olabilir. Bu durumda alacaklının bu beyanının en azından sözü geçen müteselsil borçlu arasındaki ilişkiyi sona erdirip erdirmediği, diğer bir ifade ile bu dönme beyanının geçerli olup olmadığı ele alınmalıdır. Zira bu soruya verilecek cevap birçok noktada önem arz etmektedir. Bu soruya verilecek cevaba göre; diğer müteselsil borçlular hakkında dönmenin şartları gerçekleştiğinde, bu borçluya tekrar bir dönme beyanında bulunulması gerekip gerekmediği tespit edilecek; alacaklının borçludan ifayı talep etmeye devam edip edemeyeceği belirlenecek; dönme beyanında bulunulmuş müteselsil borçlunun daha sonra yapmak istediği ifanın, borçlunun mu yoksa üçüncü kişinin ifası mı teşkil edeceği belirlenecek ve buna bağlı olarak bu borçlunun rücu hakk1 tayin edilecektir.

Doktrinde savunulan bir görüşe göre ${ }^{201}$ burada alacaklının temerrüde düşen borçluya karşı sözleşmeden dönmesi geçerli olur. Dönmenin etkisi sadece bu borçlu açısından söz konusu olur ve bu borçlu artık karşı edimi talep edemez ve alacaklının temerrütten dolayı uğradığı zarardan da münhasıran sorumlu olur. Diğer müteselsil borçlular ile alacaklı arasındaki ilişki ise devam eder ${ }^{202}$.

Kanaatimizce alacaklının sözleşmeden dönmesi bütün müteselsil borçluların temerrüde düşmesinin ardından, bütün borçlulara yönelteceği bir beyanla mümkün

200 Benzer şekilde bkz. Buz (n 190) 296

201 Canyürek (n 7) 42-43; Feyzioğlu (n 7) 321; Dağdelen (n 9) 108-109; Şahin Caner (n 7) 246; Krauskopf (n 7), Art. 146 para. 17 ve Art. 146, para. 87. Krauskopf'a göre müteselsil borçlulardan biri hakkında sözleşmeden dönmenin şartları oluşmuş ise söz konusu borçluya karşı sözleşmeden dönülebilecektir. bkz. Krauskopf (n 7), Art. 146 para. 17 ve Art. 146, para. 87.

202 Dağdelen bu durumda diğer müteselsil borçluların borçlarının da TBK m 166/f. 2 hükmünün izin verdiği ölçüde sona ereceğini kabul etmektedir. Yazara göre ayrıca temerrüde düşen borçlunun karşı edime ilişkin talebi sona erer, alacaklının da karşı edimi bölünebilir nitelikte ise borçluya düşen miktar oranınca sona erer. Alacaklının karşı edimi bölünebilir bir nitelik arz etmez ise bu halde bir azalmadan bahsedilmez ancak, alacaklı bu halde zararını menfi zarar talebi içerisinde isteyebilir. Bkz. Dağdelen (n 9) 109. 
olmalıdır ${ }^{203}$. Dolayısıyla alacaklının sadece temerrüde düşen tek bir borçluya karş1 yaptığı dönme beyanını geçersiz olarak kabul etmek gerekir. Zira kanaatimizce müteselsil borç ilişkisi alacaklı ve borçlular arasındaki geniş anlamdaki borç ilişkisini ifade eder ve bu yönüyle geniş anlamda sözleşmeden doğan tek bir geniş anlamda borç ilişkisi mevcuttur ${ }^{204}$. Her bir münferit müteselsil borçlunun alacaklı ile söz konusu olan ve nispi olarak bağımsızlık arz eden bağı ise dar anlamda borçları bakımındandır. Bu nedenle bu geniş anlamdaki borç ilişkisinden sadece bir borçluya yapılan dönme beyanı ile bu geniş anlamdaki müteselsil borçluluk ilişkisi çözülmez. Kendisine dönme beyanında bulunulan müteselsil borçlu ile alacaklı arasında ayrı bir geniş anlamda borç ilişkisi bulunmadığından bu ilişkinin ortadan kalkması da söz konusu olmayacaktır. Bu nedenle bu dönme beyanını geçerli kabul etmemek gerekir $^{205}$.

Alacaklının tek bir müteselsil borçluya karşı dönme beyanını geçerli saymanın diğer bir sakıncası ise söz konusu durumda borçluların durumunun ağırlaşmasıdır. Yukarıda zikredilen görüşe göre temerrüde düşen müteselsil borçlu borç ilişkisinden çıkıp diğer müteselsil borçlular ile alacaklı arasında önceki gibi hukuki ilişki devam edecektir. $\mathrm{Bu}$ durumda diğer müteselsil borçlulardan borcu ifa ettiğinde temerrüde düşen borçlu borç ilişkisine artık dahil olmadığ için ona karşı TBK m 167 vd. uyarınca rücu edilmesi de mümkün olmayacaktır. Aynı zamanda söz konusu borçlunun bu borç ilişkisinden çıkması nedeniyle diğer borçluların iç ilişkideki payı da artmış olacaktır. $\mathrm{Bu}$ ise görüldüğ̈̈ üzere diğer müteselsil borçluların durumunu ağırlaştırmaktadır. Halbuki alacaklının bu aşamadaki dönme beyanını geçersiz sayılması halinde, alacaklının kendisine dönme beyanında bulunduğu borçlu, müteselsil borçlu olmaya devam edeceğinden, alacaklı ondan ifayı tekrardan talep edebileceği gibi, diğer müteselsil borçluların bu borçluya rücu etme imkânı devam edecektir.

Alacaklının temerrüde düşmüş tek bir müteselsil borçluya karşı yaptığı dönme beyanının geçerli kabul edilmesinin diğer bir sakıncası ise kanaatimizce talep edilecek tazminatlar yönündendir. Alacaklı dönme beyanı üzerine kendisine karşı sözleşmeden dönülen borçludan olumsuz zararının karşılanmasını isteyebilecektir. Diğer borçlular ile sözleşme ilişkisi devam ettiğinden diğerlerinden de ifayı kabul edebilecek; diğer borçlulardan bazıları temerrüde düştüğü takdirde ifa ve gecikme tazminatı veya ifadan vazgeçerek olumlu zararının tazminini talep edebilecektir. Görülmektedir ki bu durumda alacaklı aynı müteselsil borçluluk ilişkisi içerisinde alacaklı hem olumsuz zararını hem olumlu zararını veya gecikme tazminatını talep edebilecektir. Bu ise kanaatimizce kabul edilemez bir sonuçtur. Zira sözleşmeden doğan borç ilişkisi içerisinde alacaklı hem ifayı veya ifaya olan menfaatini, hem

203 Bu yönde bkz. Becker (n 9), Art. 146, para. 2.

204 Ayrıca bkz. Kapancı (n 5) 26, fn. 106 ve 271.

205 TBK m 117 vd. uyarınca şartları gerçekleşmiş bir dönme beyanının geçersiz sayılması, müteselsil borçluluk ilişkisinin niteliğinden kaynaklanmaktadır. 
de sözleşmenin geçersizliğinden kaynaklanan zararını talep edememelidir. Aksinin kabulü tek bir borçlu ile sözleşmesel borç ilişkisi içinde bulunsaydı elde edemeyeceği bir konuma müteselsil borçluluk sayesinde alacaklıyı kavuşturmak anlamına gelir ${ }^{206}$.

Sözleşmeden dönmenin şartlarının gerçekleşmesinin ardından alacaklının bütün borçlulara yönelteceği dönme beyanı ile müteselsil borç ilişkisini doğuran sözleşme geçmişe etkili olarak ortadan kalkmış olur. Bu durumda gerek müteselsil borçlular gerekse alacaklı edimlerini ifa etmekten kurtulur.

Yerine getirilmiş edimlerin iadesi ise sebepsiz zenginleşme hükümleri uyarınca talep edilebilir. Alacaklıya karşı yerine getirilmiş bir edim var ise alacaklı bunu yerine getirmiş olan müteselsil borçluya iade eder. Sözleşmeden dönen alacaklı edimi müteselsil borçluların tamamına ifa etmişse, müteselsil borçluların tamamı, eğer sadece borçlulardan birine ifa etmişse bu müteselsil borçlu iade eder.

Alacaklı sözleşmeden dönmesi sebebiyle uğramış olduğu zararı kusursuzluğunu ispat edememiş olan müteselsil borçlulardan talep edebilir. Kanaatimizce kusurlu müteselsil borçluların olumsuz zararın tazmini noktasında da müteselsil olarak sorumlu olduklarının kabulü gerekir.

\section{Sürekli Edimli Sözleşmelerde Sözleşmenin Feshi ve Olumlu Zararın Tazmini}

818 sayılı BK'da yer almayan yeni bir madde olan TBK m 126' da sürekli edimliin ${ }^{207}$ sözleşmeler ${ }^{208}$ açısından borçlu temerrüdü ayrıca düzenlenmiştir. Buna göre sürekli edimli bir sözleşmenin ifasına başlanmış ise alacaklının elinde iki imkân mevcuttur. Bunlardan ilki alacaklının ifa ve gecikme tazminatı isteyebilmesi; ikincisi ise alacaklının sözleşmeyi feshetmesi ve sözleşme süresinden önce sona erdiği için uğradığı zararın ${ }^{209}$ giderilmesini istemesidir.

Sürekli edimli sözleşmelerde de yine temerrüdün sonuçlarından kural olarak temerrüde düşmüş olan müteselsil borçlu sorumlu olacak, temerrüde düşmeyen borçluları bu durum etkilemeyecektir. Gecikme tazminatından kural olarak temerrüde düşmüş olan müteselsil borçlu şahsen sorumlu olur, birden fazla müteselsil borçlunun kusurları ile temerrüde düşmeleri halinde gecikme tazminatından müteselsil sorumlu olduklarını kabul etmek gerekir.

\footnotetext{
${ }^{206}$ Müteselsil borçluluğun borçluların borcun tamamından sorumlu olması, alacaklının dilediği borçluya başvurabilmesi gibi alacaklı lehine özellikleri bulunmaktadır. Ancak müteselsil borçluluğun alacaklıya normalde elde edemeyeceği menfaatleri sağlamak gibi bir amacı bulunmamaktadır.

207 Bir borçlunun zaman içerisinde, sürekli olarak ve aralıksız bir davranışını gerekli kılan edimler, sürekli edimlerdir, (ibid, §3, para. 7). Sürekli borç ilişkisi hakkında bilgi için bkz. Seliçi (n 1) "4ff”.

208 Sürekli edimli sözleşmeler hakkında bilgi için bkz. Zeynep D Taşkın, ‘İfasına Başlanmış Sürekli Edimli Sözleşmelerde Borçlu Temerrüdü’ [2018] Galatasaray Üniversitesi Hukuk Fakültesi Dergisi 429 "431ff”".

209 Burada söz konusu olan zarar olumlu zarar olacaktır. Bkz. Oğuzman and Öz, Borçlar Hukuku Genel Hükümler C. 1 (n 2) para. 1716; Taşkın (n 208) 463 Gülmelahat Doğan, 'Sürekli Borç İlişkilerinde Borçlunun Temerrüdü’ [72] ABD 385407.
} 
Sözleşmenin feshi bakımından da genel olarak sözleşmeden dönme için gerçekleşmesi gereken şartlar aranır ${ }^{210}$. Sözleşmenin feshi bakımından da bütün müteselsil borçluların temerrüde düşmesi ve gerekiyor ise ek süre verilmesinin ardından bütün müteselsil borçlulara yöneltilecek bir beyan ile sözleşmenin feshedilmesi gerekir. Sözleşmenin feshinin ardından alacaklının uğramış olduğu zararın tazmin edilmesinden de temerrüde düşmede kusuru olan borçluların müteselsilen sorumlu oldukları kabul edilmelidir.

Sözleşmenin feshi ileriye etkili olur ${ }^{211}$. Fesih tarihinden sonras1 için edimler önceden ifa edilmiş ise bunlara ilişkin karşıllklı iade talepleri gündeme gelir ${ }^{212}$. Buna göre müteselsil borçlulardan fesih tarihinden sonraki dönem için sözleşmeyi fesheden alacaklıya önceden bir ifada bulunulmuş ise bunun iadesini talep edebilir.

Sürekli edimli sözleşmelerde ifaya henüz başlanılmadan borçlu temerrüdü gerçekleşmiş ise bu halde sözleşmeden dönme söz konusu olur ve olumsuz zararın tazmini talep edilebilir ${ }^{213}$. Bu halde müteselsil borçluların durumu için sözleşmeden dönmeye ve olumsuz zararın tazminine ilişkin açıklamalarımız geçerlidir.

\section{Sonuç}

Sözleşmesel çerçevede müteselsil olarak borç altına girme farklı biçimlerde gerçekleşebilir. İlk olarak bu bir sözleşme yapmak yoluyla gerçekleşebilir. Tarafların birlikte müteselsil borçluluğu kabul etmesi, borca katılma ve sözleşmeye katılma gibi hallerde müteselsil borçluluk sözleşmeden doğar ve sözleşmesel çerçevede bir müteselsil borçluluk gerekir.

Bunun yanı sıra kanunun müteselsil borçluluğu öngördüğü hallerden bazılarında da yine sözleşmesel çerçevede müteselsil borçluluk meydana gelebilir. Burada önemli olan, kanunda müteselsil borçluluğun öngörüldüğü her halde değil, niteliği gereği bir sözleşme ilişkisi kapsamında tarafları müteselsil borçlular olarak bir araya getiren bir kanun hükmünün varlığıdır.

Sözleşmesel çerçevede bir araya gelen müteselsil borçluların temerrüdü bakımından temel kural temerrüdün şartları ve bunun sonuçlarının kural olarak her bir müteselsil borçlu bakımından bağımsız olarak değerlendirilmesidir. Ancak bazı durumlarda bunun istisnaları söz konusu olabilir.

\footnotetext{
210 Oğuzman and Öz, Borçlar Hukuku Genel Hükümler C. 1 (n 2) para. 1717. Karş. Kılıçoğlu (n 9) 938.

211 Bucher (n 4) 384; Kılıçoğlu (n 9) 937; Tercier, Pichonnaz and Develioğlu (n 2), §25, para. 1326b; Oğuzman and Öz, Borçlar Hukuku Genel Hükümler C. 1 (n 2) para. 1713; Gauch, Schluep and Emmenegger (n 9) para. 2815. Ayrıca bkz. Oğuzman and Öz, Borçlar Hukuku Genel Hükümler C. 1 (n 2) para. 1441; Kocayusufpaşaoğlu and others (n 1), §2, para. 5; Seliçi (n 1) 115 ve 119.

212 Oğuzman and Öz, Borçlar Hukuku Genel Hükümler C. 1 (n 2) para. 1716; Doğan (n 209) 407.

213 Oğuzman and Öz, Borçlar Hukuku Genel Hükümler C. 1 (n 2) para. 1717; Seliçi (n 1) 223 Taşkın (n 208) 448-449.
} 
Müteselsil borçluların borçlarının muacceliyet tarihleri ve temerrüt tarihleri birbirinden farklılaşabilir. Bir müteselsil borçlunun borcunun muacceliyetine rağmen sahip olduğu bir defi hakkını kullanması sadece bu borçlunun temerrüdüne engel olur. Alacaklının müteselsil borçlulardan biri ile bir tecil anlaşması yapması bu borçlu açısından sonuç doğurur ve bu anlaşma alacaklı tarafından anlaşma yapılan borçlunun durumunun diğer müteselsil borçlular aleyhine iyileştirilmesi olarak kabul edilemez.

Bir müteselsil borçluya yapılmış olan temerrüt ihtarı, o müteselsil borçlunun, diğer müteselsil borçlular adına ihtarı kabul etme yetkisi olmadıkça, sadece ihtarda bulunulan müteselsil borçlu açısından temerrüt sonucunu doğurur. Müteselsil borçluların tamamını temerrüde düşürmek için kural olarak tamamına ihtarda bulunmak gerekir. Ayrıca müteselsil borçlulardan bazılarının ihtara düşürülmesi için ihtara gerek bulunmayabilir. Temerrüt için ihtarın gerekip gerekmediği her bir müteselsil borçlu bakımından ayrı değerlendirilmelidir.

Temerrüdün gerçekleşebilmesi için borcun ifasının mümkün olması gerekir. Borcun konusunun herhangi bir müteselsil borçlunun kusuru olmaksızın imkânsızlaşması halinde bütün müteselsil borçlular borçlarından kurtulur. Müteselsil borçlulardan birinin kusuru ile borcun konusu imkânsızlaşmış ise taraflar bu imkânsızlıktan diğer borçluların da sorumlu olacağını kararlaştırmışlar ise diğer borçlular da müteselsil olarak sorumlu olur. Ancak bu şekilde bir kararlaştırma yoksa bu durumda olması gereken hukuk bakımından söz konusu olacak tazminattan sadece imkânsızlığa sebep olanın değil diğer borçluların da müteselsilen sorumlu olmaları kabul edilmelidir. Birden fazla müteselsil borçlu kusurları ile imkânsızlığa sebep vermiş iseler bunlar da tazminattan müteselsil olarak sorumludur.

Temerrüdün gerçekleşmesi için alacaklının ifayı kabule hazır olması da şarttır. $\mathrm{Bu}$ noktada alacaklının temerrüdü söz konusu ise borçlu temerrüdüne de engel olur. Alacaklının müteselsil borçlulardan birinin ifa teklifini reddeden alacaklının temerrüde düşmesi, diğer müteselsil borçluların temerrüdünü de engeller.

Temerrüde düşmüş her bir müteselsil borçlunun kural olarak aynen ifada bulunması mümkündür. Buna karşın alacaklı da her bir müteselsil borçludan aynen ifayı talep edebilir. Gecikme tazminatı ancak kusurlu olarak temerrüde düşmüş olan müteselsil borçludan istenebilir. Birden fazla müteselsil borçlu kusurları ile temerrüde düşmüş ise bu durumda gecikme tazminatından da müteselsil olarak sorumlu oldukları kabul edilmelidir. Kusurlu olarak temerrüde düşen müteselsil borçluların temerrüt tarihleri birbirinden farklı ise sonradan temerrüde düşen müteselsil borçlunun zarardan sorumluluğu olduğu kadarıyla müteselsil sorumluluk kabul edilmelidir. 
Beklenmedik halden temerrüde düşmüş olan müteselsil borçlu sorumlu olur. Temerrüde düşen birden fazla borçlu mevcut ise bunların beklenmedik halden sorumluluklarının da müteselsil olduğunun kabulü gerekir.

Sözleşmesel çerçevede gerçekleşen müteselsil borçlulukta, her bir borçlu ile alacaklı arasında kararlaştırılan temerrüt faizi oranı aynı olabileceği gibi farklı da olabilir. Birden fazla müteselsil borçlu temerrüde düşmüş ise temerrüt faizinden de müteselsil olarak sorumlu olmalıdır. Bu durumda işlemiş olan temerrüt faizinin ne kadarından müteselsil olarak sorumlu olunacağının belirlenmesinde, faiz oranı, temerrüdün gerçekleştiği tarih önem arz eder. Müteselsil borçlulardan temerrüt faizinden sorumlu olduğu bir durumda, temerrüde düşmeyen bir borçlunun asıl borcu ödemesi ve alacaklının bu ödemeyi çekince ileri sürmeksizin kabul etmesi halinde yine de temerrüt faizi temerrüde düşen borçludan talep edilebilir.

Alacaklının temerrüt faizi ile karşılanmayan bir aşkın zararı mevcut ise bu zararı kusuru ile temerrüde düşmüş müteselsil borçludan talep edebilir. Birden fazla müteselsil borçlu kusurları ile temerrüde düşmüş ise bu borçlular aşkın zarardan da müteselsil olarak borçludur. $\mathrm{Bu}$ son bahsedilen borçlular açısından kabul edilmesi gereken müteselsil sorumluluğun miktarı, en fazla temerrüt faizini ödeyen müteselsil borçlunun ödediği miktarı aşan zarar tutarında olmalıdır.

Karşılıklı borç yükleyen sözleşmelerde tanınan ek imkânlardan yararlanmak için verilmesi gereken ek süreden sadece kendisine ek süre verilen müteselsil borçlu yararlanabilir. Bunun yanı sıra durumun özelliklerine göre temerrüde düşmüş olan müteselsil borçlulardan bazılarına ek süre vermek gerekebilir iken bazıları bakımından ise gerekmeyebilir. Müteselsil borçlulara verilmesi gereken sürenin uygunluğu her bir müteselsil borçlu bakımından ayrı değerlendirilmelidir. Verilen süre sonucunda seçimlik hakkın kullanılması da sadece bu beyanın yöneltildiği müteselsil borçlu açısından sonuç doğurur.

Müteselsil borçlulara karşı alacaklının ifadan vazgeçerek olumlu zararın tazmininin istenebilmesi bakımından mübadele ve fark teorileri bakımından ayrım yapılarak bir sonuca varılmalıdır. İfadan vazgeçilerek olumlu zararın tazmininin istenebileceği durumlarda bu tazminat talebinin kendisine yöneltilmiş müteselsil borçludan artık ifa talep edilemez. Diğer müteselsil borçlular ise başlangıçtaki edimi ifa ederek borcu sona erdirebilirler. Bu durumda artık kendisine karşı vazgeçme beyanında bulunulan borçludan olumlu zararın istenmesi de söz konusu olmaz. Diğer taraftan temerrüde düşen borçlunun olumlu zararı tazmin etmesi ile diğer müteselsil borçluların borcu da sona erer. Birden fazla müteselsil borçlu kusurlu olarak temerrüde düşmüş ve kendilerinden olumlu zararın tazmini talep edilmiş ise bu durumda bu borçluların müteselsil olarak sorumlu olduğu kabul edilmelidir. 
Alacaklının sözleşmeden dönebilmesi için bütün müteselsil borçluların temerrüde düşmüş olması ve onlar hakkında sözleşmeden dönmenin şartlarının gerçekleşmiş olması gerekir. Bir tek müteselsil borçluya yöneltilen dönme beyanı bütün sözleşme ilişkisini ortadan kaldırmayacağı gibi bu borçlu açısından da müteselsil borçluluğun sona ermesine neden olmaz. Sözleşmeden dönmenin geçerli olabilmesi için bütün müteselsil borçlulara yöneltilen bir beyan gerekir. Sözleşmeden dönme üzerine alacaklı elde ettiği bir edim varsa bunu kendisine ifa eden müteselsil borçluya iade eder. Sözleşmeden dönen alacaklı kendi edimini borçluların tamamına ifa etmişse bu borçluların tamamı, sadece bir müteselsil borçluya ifa etmişse bu müteselsil borçlu iade ile yükümlüdür. Kusurlu müteselsil borçlular dönme üzerine söz konusu olumsuz zararın tazmininden de müteselsilen sorumlu olmalıdır.

Sürekli edimli sözleşmeler bakımından sözleşmenin feshi halinde müteselsil borçlunun durumu sözleşmeden dönmedeki durum ile benzerlik gösterir.

Finansal Destek: Yazar bu çalışma için finansal destek almamıştır. 


\section{Bibliyografya/Bibliography}

Akıntürk T, Müteselsil Borçluluk (AÜHF Yayınları 1971).

Akkanat H, 'İfada Gecikme ve Borçlu Temerrüdü', Prof. Dr. M. Kemal Oğuzman'in Anisina Armağan (Beta 2000).

Arat A, 'Müteselsil Borçlarda Alacaklı ile Borçlular Arasındaki İlişkinin Hüküm ve Sonuçları' (2018) 26(2) SÜHFD 325.

Arsebük E, Borçlar Hukuku C. 1 ve C. 2 (3rd edn, Güney Matbaacılık ve Gazetecilik 1950).

Aydın Ünver T, 'Tacirler Arası İhbar ve İhtarlara İlişkin Şeklin Hukuki Niteliği’, Prof. Dr. Hasan Erman'a Armağan (Der 2015).

Ayranc1 H, Türk Borçlar Hukukunda Munzam Zarar (BK m 105) (Yetkin 2006).

Bahadır Z, 'Sözleşmenin Devri ve Sözleşmeye Katılma' (2013) 17(3) Gazi Üniversitesi Hukuk Fakültesi Dergisi 1.

Barlas N, Para Borçlarının Ifasında Borçlunun Temerrüdü ve Bu Temerrüt Açısından Düzenlenen Genel Sonuçlar (Kazanc1 1992).

Becker H, Berner Kommentar,B. VI, Obligationenrecht Allgemeine Bestimmungen, Art. 1-183 OR (2nd edn, Stämpfli 1945).

Berger B, Allgemeines Schuldrecht (3rd edn, Stämpfli 2018).

Bozer A, Borçlar Hukuku Genel Hükümler (2nd edn, Banka ve Ticaret Hukuku Araştırma Enstitüsü 2007).

Brox H and Walker Wolf-Dietrich, Allgemeines Schuldrecht (39th edn, C.H. Beck 2015).

Bucher E, Schweizerisches Obligationenrecht: Allgemeiner Teil ohne Deliktsrecht (2.th edn, Schulthess 1988).

Buz V, Borçlunun Temerrüdünde Sözleşmeden Dönme (T1pkı Basım, Yetkin 2014).

Büren Bv, Schweizerisches Obligationenrecht Allgemeiner Teil (Schultess \& Co 1964).

Canbolat F, 'Müteselsil Borcun Sona Erme Nedenleri: Borçlar Kanunu Tasarısı'ndaki İlgili Hükümlerin Kısa Değerlendirilmesi ile Birlikte' (Yaz 2008) 66(3) ABD 68.

Canyürek M, Müteselsil Borçlulukta İç ve Dış İlişkiler (Vedat Kitapçılık 2003).

Dağdelen AH, 818 ve 6098 Sayılı Borçlar Kanunlarında Borçlular Arasında Teselsül (On İki Levha 2011).

Dalamanlı L, Kazancı F and Kazancı M, İlmi ve Kazai Içtihatlarla Açıklamalı Borçlar Kanunu C. 2 (Kazanc1 1990).

Doğan G, ‘Sürekli Borç İlişkilerinde Borçlunun Temerrüdü’ [72] ABD 385.

Edgü E, Borçlar Hukuku Umumi Hükümler (İ.İ.T.İ.A Nihat Sayar Yayın ve Yardım Vakfı 1978).

Erdem M, Özel Hukukta Zamanaşımı (1st edn, On İki Levha 2010).

Erdoğan İ, Borçlar Hukuku Genel Hükümler (3rd edn, Gazi Kitabevi 2017).

Eren F, Borçlar Hukuku Genel Hükümler (23. bask1, Yetkin 2018).

Erlüle F, 'Müteselsil Kefalet ve Müteselsil Borçluluk Kavramlarının Karşılaştırılması' (2003) 7(12) AÜEHFD 629.

Feyzioğlu FN, Borçlar Hukuku Genel Hükümler, C. 2 (2nd edn, IÜHF Yayınları 1977).

Fikentscher W and Heinemann A, Schuldrecht Allgemeiner und Besonderer Teil (11.th edn, De Gruyter 2017).

Funk F, Borçlar Kanunu Şerhi I Umumi Hükümler (Üniversite Kitabevi n.d).

Furrer A and Müller-Chen M, Obligationenrecht, Allgemeiner Teil (3rd edn, Schulthess 2018). 
Gauch P, Schluep WR and Emmenegger S, Schweizerisches Obligationenrecht, Allgemeiner Teil, B. 2 (10th edn, Schulthess 2014).

Gautschi A, Solidarschuld und Ausgleich (Dike 2009).

Göktürk HA, Borçlar Hukuku, Birinci Kısım, Borçların Umumi Hükümleri (1946).

Graber CK, 'Art. 143-150' in Heinrich Honsell, Nedim P Vogt and Wolfgang Wiegand (eds), Basler Kommentar, Obligationenrecht I, Art. 1-529 OR (6 $6^{\text {th }}$ edn. Helbing Lichtenhahn Verlag 2015).

Guhl T, Das Schweizerische Obligationenrecht : mit Einschluss des Handels- und Wertpapierrechts (9th edn, Schulthess 2000).

Hatemi H and Gökyayla E, Borçlar Hukuku Genel Bölüm (4th edn, Vedat Kitapçılık 2017).

Havutçu A, Tam İki Tarafa Borç Yükleyen Sözleşmelerde Temerrüt ve Müsbet Zararın Tazmini (Dokuz Eylül Üniversitesi Hukuk Fakültesi Döner Sermaye İşletmesi Yayınları 1995).

Huguenin C, Obligationenrecht Allgemeiner und Besonderer Teil (2nd edn, Schulthess 2014).

İnan AN and Yücel Ö, Borçlar Hukuku Genel Hükümler (4th edn, Seçkin 2014).

İyimaya A, 'Zincirleme Sorumlulardan Yalnızca Biri Aleyhine Açılan Davada 'Zincirleme Sorumluluk Kaydı'nın Yeralması Zorunlu Mudur?' [1995] TBBD 378.

Jung P, ‘Art. 143-150’ in Heinrich Honsell (ed), Kurzkommentar OR (Helbing Lichtenhahn 2014).

Kaniti S, Akdin İfa Edilmediği Def’i (İ̈HHF Yayınları 1962).

Kapancı KB, Birlikte Borçlulukta Borçlular Arası İlişkiler (2.th edn, Vedat Kitapçılık 2014).

Karabağ Bulut N, 'Tacirler Arası İhbar ve İhtarlar Bakımından Getirilen Şeklin Geçerlilik Veya İspat Şartı Şeklinde Nitelendirilmesine Bağlı Olarak Doğuracağı Hukuki Sonuçlar', Prof. Dr. Hasan Erman'a Armağan (Der 2015).

Karahasan MR, Türk Borçlar Hukuku Genel Hükümler, C. 2 (Beta 2003).

Keller M and Schöbi Christian, Das Schweizerische Schuldrecht, B. 4, Gemeinsame Rechtsinstitute für Schuldverhältnisse aus Vertrag, unerlaubter Handlung und ungerechtfertigter Bereicherung (2nd edn, Helbing Lichtenhahn 1985).

- Keller, Max/Schöbi, Christian, Das Schweizerische Schuldrecht, B. 1, Allgemeine Lehren des Vertragrechts (3rd edn, Helbing Lichtenhahn 1988).

K1lıçoğlu A, Borçlar Hukuku Genel Hükümler (22nd edn, Turhan 2018).

Kırca Ç, 'Müteselsil Sorumlulukta Borçlar Kanunu Tasarısı ile Getirilen Değişiklikler', Prof. Dr. Fikret Eren'e Armağan (Yetkin 2006).

Kocayusufpaşaoğlu N and others, Borçlar Hukuku Genel Bölüm, C. 1 (5th edn, Filiz Kitabevi 2010).

Koller A, Schweizerisches Obligationenrecht Allgemeiner Teil (4th edn, Stämpfli 2017).

Kramer EA and Probst T, Obligationenrecht Allgemeiner Teil (2.th edn, Helbing Lichtenhahn 2013).

Kratz B, Obligationenrecht, Solidarität, Art. 143-150 OR (Berner Kommentar Kommentar zum schweizerischen Privatrecht, Stämpfli 2015).

Krauskopf F, Art. 143-150 OR, Die Solidarität (Zürcher Kommentar Obligationenrecht, 3rd edn, Schulthess 2016).

Kurt LM, Borçlunun Sorumlu Olmadiğı Sonraki Imkânsızlık (TBK m 136) (Yetkin 2016).

Larenz K, Lehrbuch des Schuldrechts, B. 1, Allgemeiner Teil (14th edn, C.H. Beck 1987).

Mazan S, 'Art. 143-150 OR' in Andreas Furrer and Anton K Schnyder (eds), Handkommentar zum Schweizer Privatrecht Obligationenrecht Allgemeine Bestimmungen (3rd edn. Schulthess 2016).

Medicus D and Lorenz S, Schuldrecht I, Allgemeiner Teil (21st edn, Beck 2015). 
Müller T, 'Art. 143-150 OR' in Jolanta Kren Kostkiewicz and others (eds), OR Kommentar, Schweizerisches Obligationenrecht (3. ${ }^{\text {th }}$ edn. Orell Füssli 2016).

Oğuzman MK and Öz MT, Borçlar Hukuku Genel Hükümler C. 1 (16th edn, Vedat Kitapçılık 2018).

- Borçlar Hukuku Genel Hükümler C. 2 (14th edn, Vedat Kitapçılık 2018).

Olgaç S, Kazai ve İlmi İçtihatlarla Türk Borçlar Kanunu Genel Hükümler (3rd edn, İsmail Akgün Matbaas1 1970).

Oser H and Schönenberger W, Ísviçre Borçlar Kanunu Şerhi, Madde 110-183 (Şerhin İkinci Basılışının Tercümesi, Adalet Bakanlığı 1950).

Önen T, Borçlar Hukuku Genel Hükümler (5th edn, Yarg1 1999).

Öz MT, 'Borçlu Temerrüdünde Sözleşmeden Dönmenin Bu Sözleşme Gereğince Kazanılmış Ayni Haklara Etkisi ve Klasik Dönme Kuramı ile Yeni Dönme Kuramının Kısa Bir Karşılaştırmalı Eleştirisi' [13] MHAD 131.

Paksoy MS, Zamanaşımından Feragat (TBK 160) (1st edn, On İki Levha 2012).

Pekmez C, Borcun İfa Edilmediği Defi (Ödemezlik Defi) (On İki Levha 2019).

Reisoğlu S, Türk Borçlar Hukuku Genel Hükümler (25th edn, Beta 2014).

Saymen FH and Elbir HK, Türk Borçlar Hukuku I, Umumi Hükümler C. 2 (İsmail Akgün Matbaası 1958).

Schwenzer I, Schweizerisches Obligationenrecht Allgemeiner Teil (7th edn, Stämpfli 2016).

Seliçi Ö, Borçlar Kanununa Göre Sözleşmeden Doğan Sürekli Borç Illişkilerinin Sona Ermesi (İ̈HF Yayınları 1976).

Serozan R, Sözleşmeden Dönme (2nd edn, Vedat Kitapçılık 2007).

Şahin Caner A, Türk Borçlar Kanununda Müteselsil Borçluluk (On İki Levha 2017).

Şener OH, Teorik ve Uygulamalı Ortaklıklar Hukuku (3rd edn, Seçkin 2017).

Taşkın ZD, ‘İfasına Başlanmış Sürekli Edimli Sözleşmelerde Borçlu Temerrüdü’ [2018] Galatasaray Üniversitesi Hukuk Fakültesi Dergisi 429.

Tekinay SS, Borçlular Arasında Akdi Teselsül, (Yayımlanmamış Doçentlik Tezi) (1956).

- 'Müteselsil Borç ile Kefalet Arasında Bir Mukayese' (1956) 47(7) Adalet Dergisi 742.

Tekinay SS and others, Borçlar Hukuku Genel Hükümler (7th edn, Filiz Kitabevi 1993).

Tercier P, Pichonnaz P and Develioğlu HM, Borçlar Hukuku Genel Hükümler (On İki Levha 2016).

Tuhr A von and Escher A, Allgemeiner Teil des Schweizerischen Obligationenrechts, B. II. (3rd edn, Schulthess 1984).

Tunçomağ K, Türk Borçlar Hukuku Genel Hükümler, C. 1 (Sermet Matbaas1 1976).

Turan Başara G, 'Türk Borçlar Kanunuyla Getirilen Yeni Bir Müessese: Borca Katılma' (2014) 63(2) AÜHFD 419.

Velidedeoğlu HV and Özdemir R, Türk Borçlar Kanunu Şerhi (Genel-Özel) (Yargıtay Yayınları 1987).

Weiss A, Solidarität nach Art. 143-149 des Schweizerischen Obligationenrechts unter besonderer Berücksichtigung der Verjährung (Schulthess 2011).

Yavuz C, Acar F and Özen B, Türk Borçlar Hukuku Özel Hükümler (10th edn, Beta 2014).

Yüce MB, Alacaklı ve Borçlu Açısından Ifa Zamanı (Vedat Kitapçılık 2015). 
